
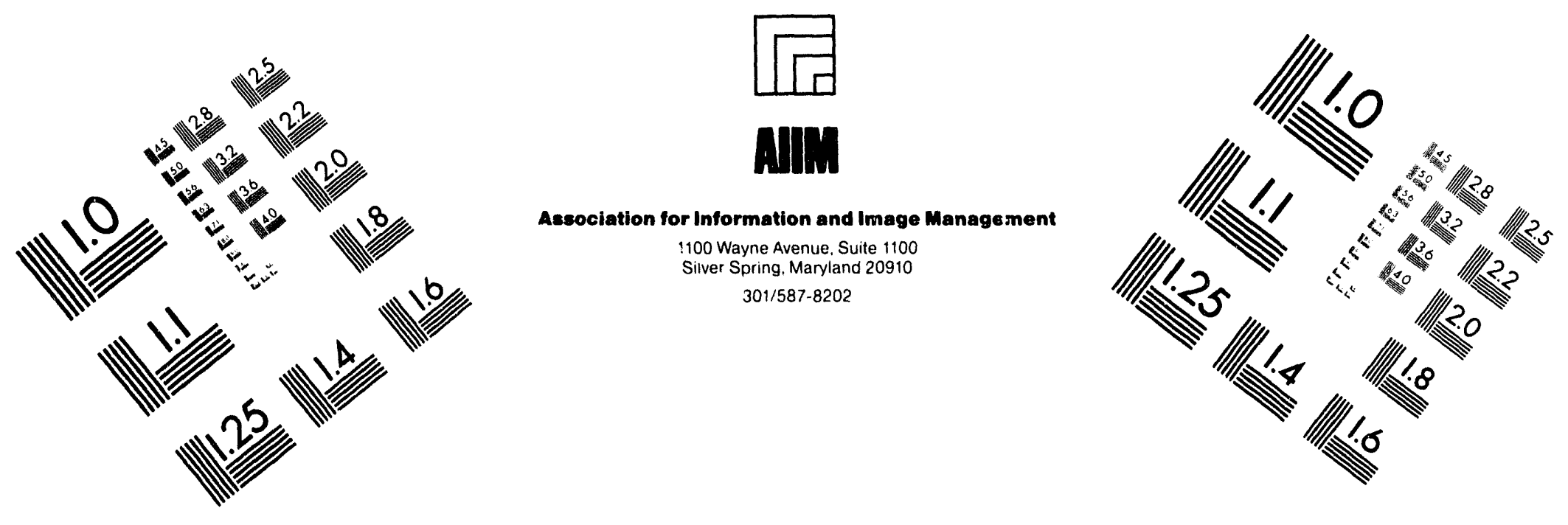

\title{
Centimeter
}

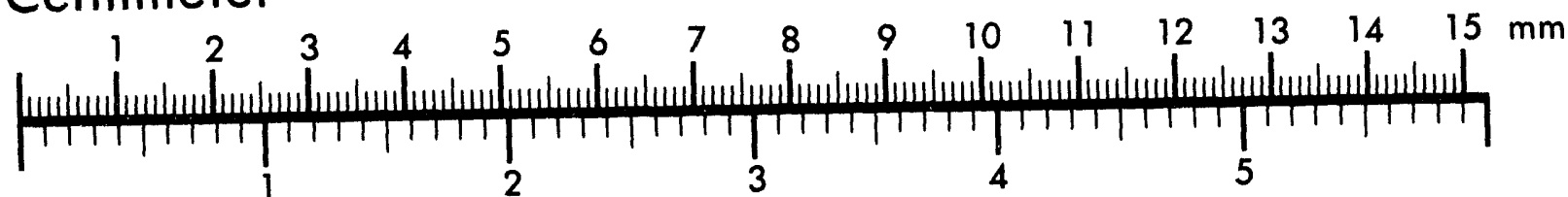
Inches
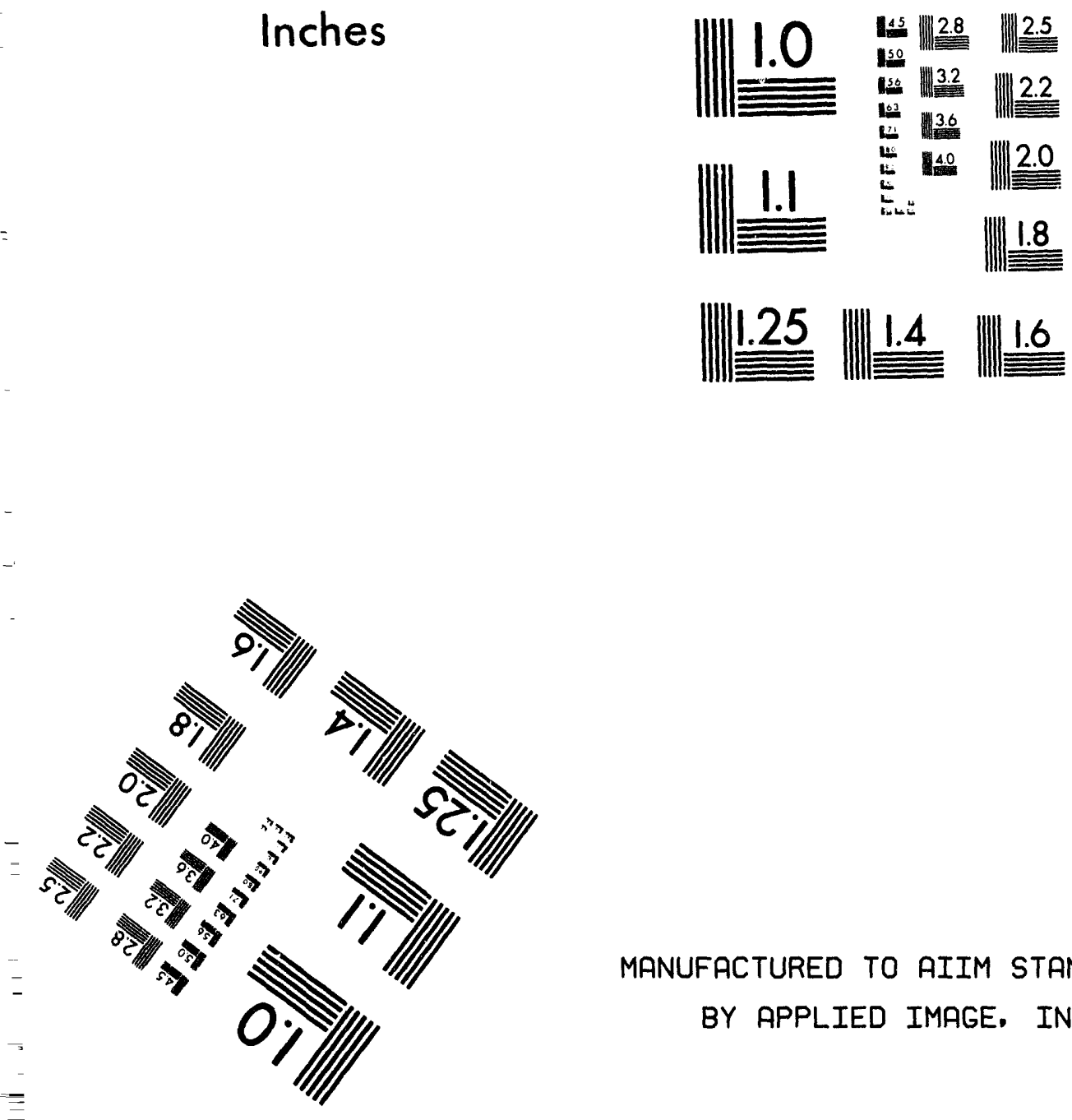

MANUFACTURED TO AIIM STANDARDS

BY APPLIED IMAGE, INC.

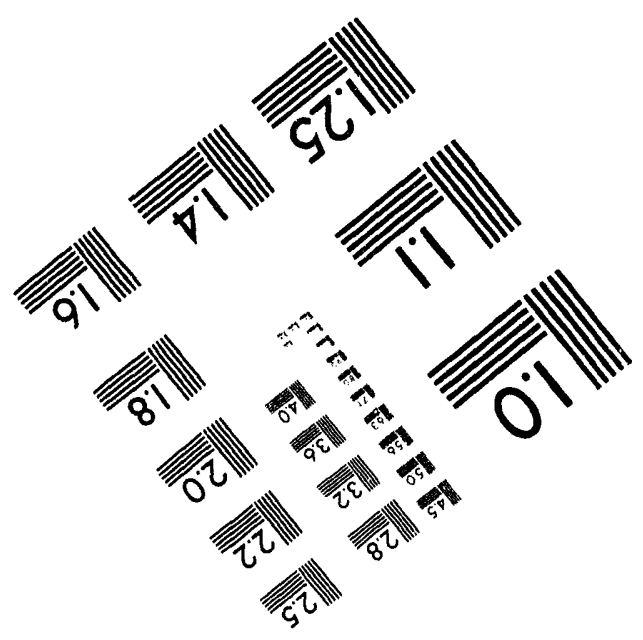



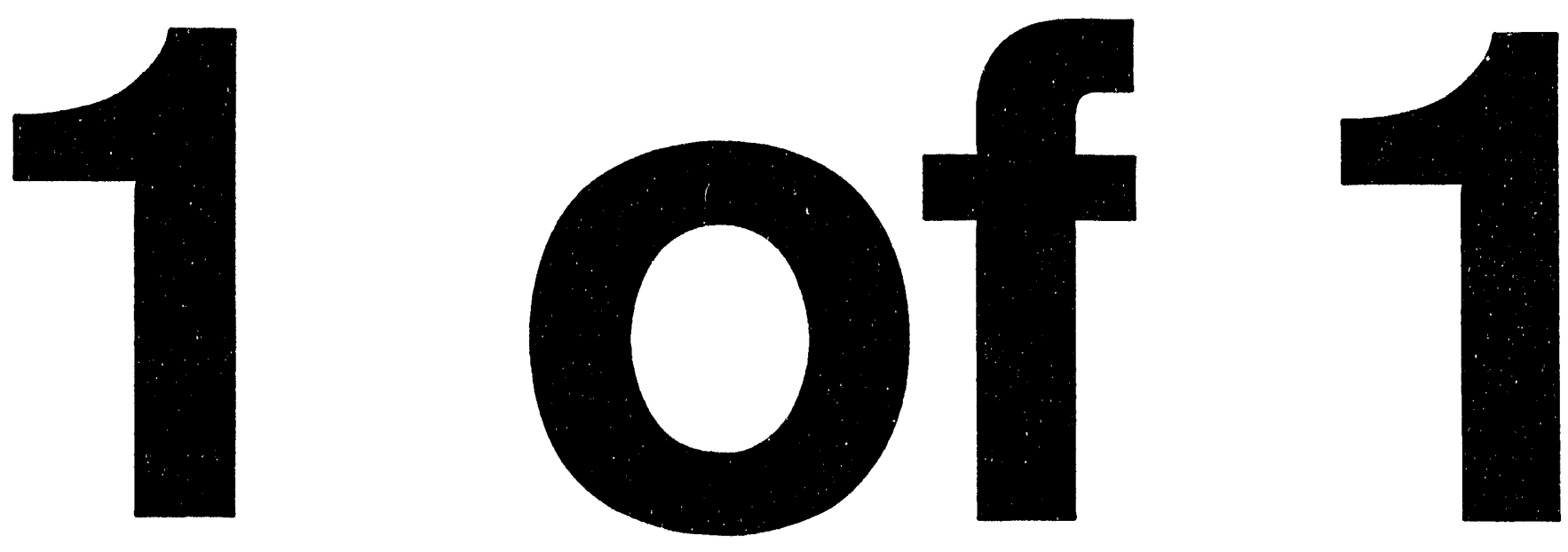


\section{Gunnison, Colorado, SUbPILE StUdy REPORT}

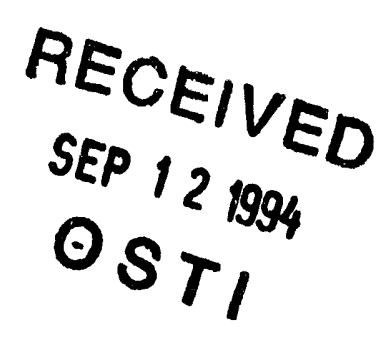

August 1994 


\section{INTENDED FOR PUBLIC RELEASE}

This report has been reproduced from the best available copy. Available in paper copy and microfiche.

Number of pages in this report: 94

DOE and DOE contractors can obtain copies of this report from: (w)

Office of Scientific and Technical Information

P.0. Box 62

Oak Ridge, TN 37831

(615) 576-8401

This report is publicly available from:

National Technical Information Service

Department of Commerce

5285 Port Royal Road

Springfield, VA 22161

(703) 487-4650 


\title{
GUNNISON, COLORADO, SUBPILE STUDY REPORT
}

August 1994

\author{
Prepared for \\ U.S. Department of Energy \\ UMTRA Project Office \\ Albuquerque, New Mexico
}

\author{
Prepared by \\ Jacobs Engineering Group Inc. \\ Albuquerque, New Mexico
}

\section{DISCLAIMER}

\begin{abstract}
This report was prepared as an account of work sponsored by an agency of the United States Government. Neither the United States Government nor any agency thereof, nor any of their employees, makes any warranty, express or implied, or assumes any legal liability or responsibility for the accuracy, completeness, or usefulness of any information, apparatus, product, or process disclosed, or represents that its use would not infringe privately owned rights. Reference herein to any specific commercial product, process, or service by trade name, trademark, manufacturer, or otherwise does not necessarily constitute or imply its endorsement, recommendation, or favoring by the United States Government or any agency thereof. The views and opinions of authors expressed herein do not necessarily state or reflect those of the United States Government or any agency thereof.
\end{abstract}




\section{EXECUTIVE SUMMARY}

To protect human health and the environment, the Uranium Mill Tailings Remedial Action (UMTRA) Project will remediate the uranium mill tailings site at Gunnison Colorado. There are explicit requirements (i.e., 40 CFR Part 192) for the surface remediation of radiologically contaminated soils on UMTRA sites. The removal of subpile sediment to the depth required by 40 CFR Part 192 will leave in place deeper foundation sediment that is contarninated with hazardous constituents other than radium-226 and thorium-230. The Department of Energy and the Colorado Department of Health have questioned whether this contaminated soil could potentially act as a continuing source of ground water contamination even after surface remediation based on 40 CFR Part 192 is complete. To evaluate the subpile sediments as a potential source of ground water contamination, the Gunnison Subpile study was initiated. This report summarizes the results and findings of this study.

Batch tests of subpile sediments indicate that many hazardous trace constituents are associated with elevated levels of iron and manganese in these solutions, strongly suggesting that iron and manganese hydroxides are the largest reservoirs of trace metals in the subpile sediments. The mill at Gunnison operated from 1958 until 1962 and iron and manganese hydroxides have been deposited in the subpile sediments by infiltrating acidic tailings pore water for over thirty years. Consequently, the iron-and manganese-rich coatings on these sediments have built up gradually and trace metals associated with these coatings are not simply adsorbed to the present-day surface, but are found throughout the three dimensicnal framework of these solid phases. To solubilize the trace metals sequestered within the iramework of the coatings, the coatings themselves must be dissolved. Iron and manganese hydroxides will only be significantly solubilized under acidic or reducing ground water conditions. Reducing conditions are extremely unlikely to develop in the shallow, oxidized sediments of the Gunnison subpile environment.

If the ground water table at the Gunnison processing site were to rise 3 to 6 feet $(1$ to 1.8 meters) (approximately to ground level) into the subpile sediment, the ground water within the strongly acidified parts of the subpile sediment (not excavated under surface cleanup criteria) would be acidified and would solubilize many constituents such as iron, manganese, arsenic, thorium, zinc, cadmium, molybdenum, and uranium. As this acidified (low $\mathrm{pH}$ ) and contaminated ground water moved laterally or vertically away from the acidified sediments, its acidity would be neutralized by less contaminated, calcium carbonate-bearing sediments and by mixing with high-pH, alkaline ground water. All trace metals discussed above except uranium and molybdenum would be strongly sorbed by iron and manganese hydroxides as the $\mathrm{pH}$ increased. Owing to their mobility in alkaline, high $\mathrm{pH}$ ground water, uranium and molybdenum could potentialy be transported from the low$\mathrm{pH}$ subpile sediments and mixed with ground water outside the immediate area of the subpile sediments. Batch and column test data, however, demonstrate that acidic subpile sediments solubilize tens to hundreds of times more uranium than molybdenum. Furthermore, aven though uranium is a significant ground water contaminant at Gunnison, molybdenum is not. These factors suggest that molybdenum will not be a problem for ground water quality after surface remediation. 
Batch and column tes $t$ data further demonstrate that acidic subpile sediments solubilize tens to hundreds of times more uranium than alkaline subpile sediments with similar total levels of uranium. The bulk of the readily soluble uranium is present, therefore, in the acidified parts of the subpile sediment. Acidity measurements on sediments from subpile test pits have demonstrated that the depth of strong acidification varies from less than a foot to a maximum of about 3 to 4 feet across the footprint of the tailings. In many subpile areas, the planned excavation of radium-226 and thorium-230 contaminated soil will also remove most of the soluble uranium. In the area of test pit 16, however, high concentrations of soluble uranium extend below the estimated depth of cleanup. If the depth of excavation in the area of test pit 16 is completed to a depth of 3 feet (1 meter) below the tailings subpile interface, or until the sediment pH climbs above 5.0, the bulk of the subpile sediment with soluble uranium will be removed. 


\section{TABLE OF CONTENTS}

Section Page

EXECUTIVE SUMMARY $\ldots \ldots \ldots \ldots \ldots \ldots \ldots \ldots \ldots \ldots \ldots \ldots \ldots \ldots$

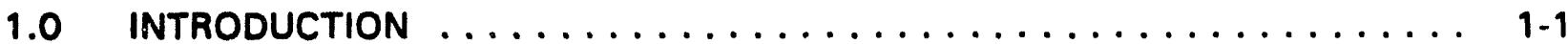

1.1 Geologic setting .......................... 1-1

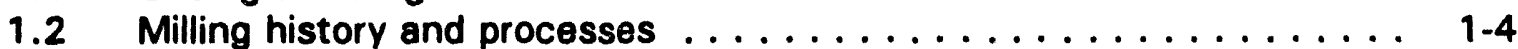

1.3 Tailings ............................. $1-4$

1.4 Hydrogeology and hydrochemistry of the alluvial aquifer . . . . . . 1-4

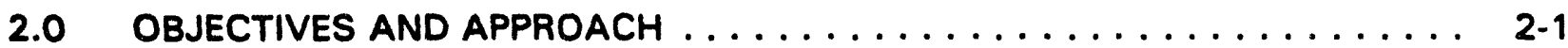

3.0 SAMPLE COLLECTION AND PREPARATION PROCEDURES $\ldots \ldots \ldots \ldots \ldots$

3.1 Sampling locations . . . . . . . . . . . . . . .

3.2 Sediment sampling and processing procedures $\ldots \ldots \ldots \ldots \ldots \ldots$ 3-1

4.0 PHYSICAL AND MINERALOGICAL CHARACTERIZATION $\ldots \ldots \ldots \ldots . \ldots$. . . 1

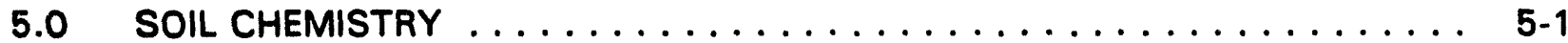

5.1 Relative soil alkalinity and acidity ................. 5-1

5.2 EPA Method 3050 and total soil digestion results . . . . . . . . 5-1

5.3 Batch tests ........................ 5-7

5.4 Column tests ........................ 5-11

5.4.1 $\mathrm{pH}$, conductivity, and alkalinity ............. 5-19

5.4 .2 Major and minor constituents . . . . . . . . . . . 5-35

5.4 .3 Trace constituents .................. 5-41

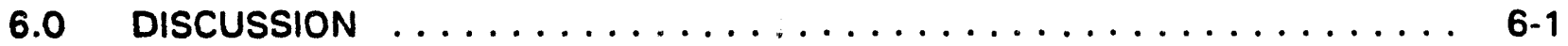

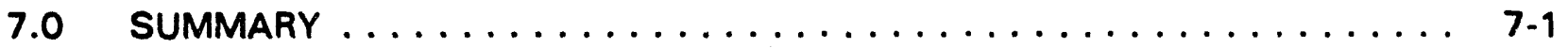

8.0 CONCLUSIONS $\ldots \ldots \ldots \ldots \ldots \ldots \ldots \ldots \ldots \ldots \ldots \ldots \ldots \ldots \ldots$

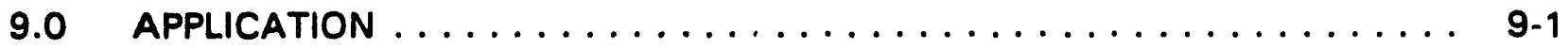

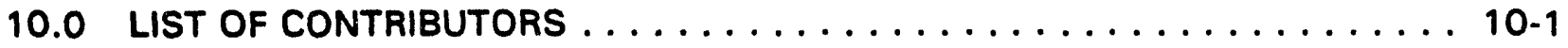

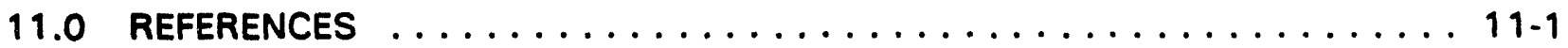

ATTACHMENT A LITHOLOGIC LOGS OF TEST PITS 19, 20, 21, 22 AND 23

ATTACHMENT B SOIL ALKALINITY AND ACIDITY MEASUREMENTS

ATTACHMENT C COLUMN CONSTRUCTION AND EXPERIMENTAL PROCEDURE 


\section{LIST OF FIGURES}

Fiqure

Page

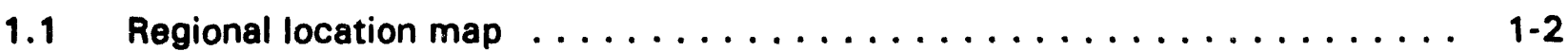

1.2 Location of the processing site at Gunnison, Colorado . . . . . . . . . . . 1-3

1.3 Approximate extent of uranium contamination, Gunnison processing site, Gunnison, Colorado .......................... 1-5

3.1 TAC test pit locations map, Gunnison processing site, Colorado . . . . . . 3-2

5.1 Method 3050 metals concentrations and total dissolution thorium-230 activity versus sample depth below tailings/alluvium interface $\ldots \ldots \ldots \ldots .5-5$

5.2 Sample depth versus final pH of batch test solutions for the on-site test pits . 5-12

5.3 Subpile sediment batch test metals concentrations versus final pH of batch test solutions ............................. 5-13

5.4 Alkalinity of background ground water influent solution used in the Gunnison subpile column experiment . . . . . . . . . . . . . . 5-17

5.5 $\mathrm{pH}$ of background ground water influent solution used in the Gunnison subpile column experiment .................... 5-18

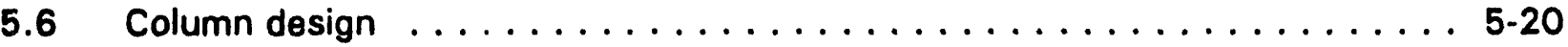

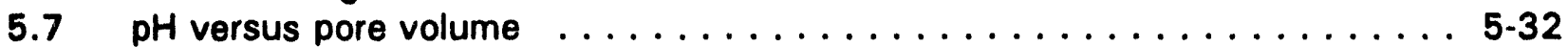

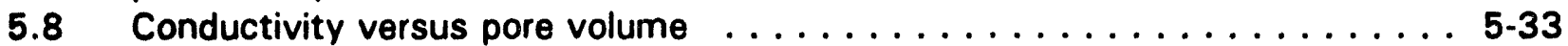

5.9 Calcite and gypsum saturation relationships for column test solutions, Gunnison subpile study . . . . . . . . . . . . . . . . . . 5-34

5.10 Background alkalinity versus pore volume $\ldots \ldots \ldots \ldots \ldots \ldots \ldots \ldots$

5.11 Alkalinity versus pore volume . . . . . . . . . . . . . . . 5 5-37

5.12 Concentrations of major and minor constituents versus pore volume . . . . 5 5-39

5.13 Concentrations of trace constituents versus depth $\ldots \ldots \ldots \ldots \ldots \ldots \ldots$ 5-42

5.14 Column 4 (subpile pit 19) cadmium and zinc concentrations versus pore volume ........................... 5-44

9.1 Subpile test pit locations $\ldots \ldots \ldots \ldots \ldots \ldots \ldots \ldots \ldots \ldots \ldots \ldots \ldots$ 


\section{LIST OF TABLES}

Table

Page

4.1 Gunnison subpile sample sieve analyses by $\%$ weight . . . . . . . . . . . . . 4-2

4.2 Selected chemical and grain size analysis of sediments from test pits $19-23 \ldots \ldots \ldots \ldots \ldots \ldots \ldots \ldots \ldots \ldots \ldots \ldots \ldots \ldots \ldots$ 4.3

4.3 XRD analysis of subpile and background sediments in approximate wt $\% \ldots$. . 4-4

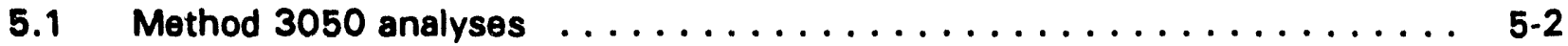

5.2 Soil total dissolution radionuclide lab results $(<\# 4$ material $) \ldots \ldots \ldots \ldots$

5.3 Parameters and analytical values for the master solution used in the column tests and acidified solution used in the batch tests for the Gunnison subpile study . . . . . . . . . . . . . . . . . . . 5-8

5.4 Batch test data for < \#4 mesh sample material, acid leach $(=2.4 \mathrm{pH}) \ldots 5-9$

5.5 Acid leach batch test data of iron-hydroxide-coated pebbles . . . . . . . 5-15

5.6 Gunnison subpile column 1-5 test results . . . . . . . . . . . . . . . 5-21

5.7 Column test-composite thorium-230 results for subpile test pits $\ldots \ldots \ldots \ldots$. . . 51

B.1 Relative soil alkalinity or acidity $\ldots \ldots \ldots \ldots \ldots \ldots \ldots \ldots \ldots \ldots$ B-2

C.1 Packing sequence, material type, and other information pertinent to the column experiment Gunnison subpile study, Gunnison, Colorado . . . . . . . C.2 


\section{LIST OF ACRONYMS AND ABBREVIATIONS}

\section{Acrenym Definition}

$\begin{array}{ll}\text { ALARA } & \text { as low as is reasonably achievable } \\ \text { ASTM } & \text { American Society for Testing and Materials } \\ \mathrm{CaCO}_{3} & \text { calcium carbonate } \\ \mathrm{CdCO}_{3} & \text { octavite (cadmium carbonite) } \\ \mathrm{CDH} & \text { Colorado Department of Health } \\ \mathrm{cm} & \text { centimeter } \\ \mathrm{DOE} & \text { U.S. Department of Energy } \\ \text { EHPA } & \text { di(2-ethylhexyl) phosphoric acid } \\ \mathrm{ft} & \text { foot } \\ \mathrm{H}_{2} \mathrm{SO}_{4} & \text { sulfuric acid } \\ \mathrm{ICP}-\mathrm{MS} & \text { inductively coupled plasma-mass spectrometer } \\ \mathrm{m} & \text { meter } \\ \mu \mathrm{m} & \text { micrometer } \\ \mu \mathrm{S} / \mathrm{cm} & \text { microsiemins/centimeter } \\ \mathrm{MK}-\mathrm{F} & \text { Morrison Knudsen-Ferguson } \\ \mathrm{mL} & \text { millititer } \\ \mathrm{NaHCO} & \text { sodium bicarbonate } \\ \mathrm{NaOH} & \text { sodium hydroxide } \\ \text { pCi/g } & \text { picocuries per gram } \\ \mathrm{Ra}-226 & \text { radium-226 } \\ \mathrm{RAC} & \text { Remedial Action Contractor } \\ \mathrm{TAC} & \text { Technical Assistance Contractor } \\ \mathrm{Th}-230 & \text { thorium-230 } \\ \mathrm{U}_{3} \mathrm{O}_{8} & \text { uranium oxide } \\ \mathrm{UMTRA} & \text { Uranium Mill Tailings Remedial Action } \\ \text { Wt\% } & \text { percent by weight } \\ \text { XRD } & \text { x-ray diffraction } \\ & \end{array}$




\subsection{INTRODUCTION}

To protect human health and the environment, the U.S. Department of Energy (DOE) Uranium Mill Tailings Remedial Action (UMTRA) Project is planning to remove uranium mill tailings and contaminated soils from the Gunnison, Colorado processing site and relocate them to a secure location. Explicit requirements exist (40 CFR Part 192 (1993)) for the surface remediation of radiologically contaminated soils on UMTRA Project sites. These requirements include limits of 5 picocuries per gram (pCi/g) radium-226 (Ra-226) above background for the initial 15-centimeters $(\mathrm{cm})$ deep soil layer and $15 \mathrm{pCi} / \mathrm{g} \mathrm{Ra-226}$ above background for the underlying $15-\mathrm{cm}$ deep soil layer. These activities are averaged over an area of 100 square meters $\left(\mathrm{m}^{2}\right)$. If elevated levels of other radionuclides (e.g. thorium-230 [Th-230]) are encountered at soil depths greater than that of elevated Ra-226, the supplemental standards provisions of 40 CFR \$192.21 and 40 CFR \$192.22 apply. These provisions provide guidance for the remediation of radionuclides other than Ra-226 to levels that meet the Ra-226 standard, or to levels that are as low as reasonably achievable (ALARA). Although this is a valid approach for removing the radiological hazards at this and other UMTRA sites, the DOE and Colorado Department of Health (CDH) have questioned whether this approach would leave in place foundation soil that is below the depth of cleanup required by 40 CFR Part 192, yet remains contaminated with uranium and nonradiological hazardous constituents. If this occurs, the contaminated soil could act as a source of continuing ground water contamination after surface remediation has been completed. To evaluate the potential of the subpile sediments to act as a continuing source of ground water contamination, the Gunnison Subpile Study was initiated. This report summarizes the methods, results, and conclusions of the study.

\subsection{GEOLOGIC SETTING}

The Gunnison processing site is located in south-central Colorado (Figure 1.1), in the Southern Rocky Mountain Province of the Rocky Mountains (Hunt, 1967). Topography in this region is characterized by mountain peaks above 14,000 feet (ft) ( 4000 meters $[\mathrm{m}]$ ) and steep valleys, some of which were impacted by Pleistocene glaciation.

The bedrock geology of the surrounding hills consists of Precambrian igneous and metamorphic rocks overlain unconformably by a relatively thin sequence of sedimentary rocks. The sedimenting strata consist of the Morrison Formation, the Dakota Sandstone, and the Mancos Shale. The sedimentary stratigraphic sequence is overlain by volcanic sequences of Cenozoic age. During Pleistocene time, the Gunnison River and Tomichi Creek carved deep valleys into the bedrock hills and then filled the valleys with 100 to $200 \mathrm{ft}(30$ to $60 \mathrm{~m})$ of alluvial sand, gravel, and cobbles.

The processing site is located near the Gunnison airport, on the floodplain alluvium of the Gunnison River and Tomichi Creek (Figure 1.2). The alluvium consists of poorly sorted material ranging from clay-sized particles to cobbles and boulders. Underlying the alluvium is the Morrison Formation, which in the vicinity of the processing site is discontinuous and of unknown extent. 


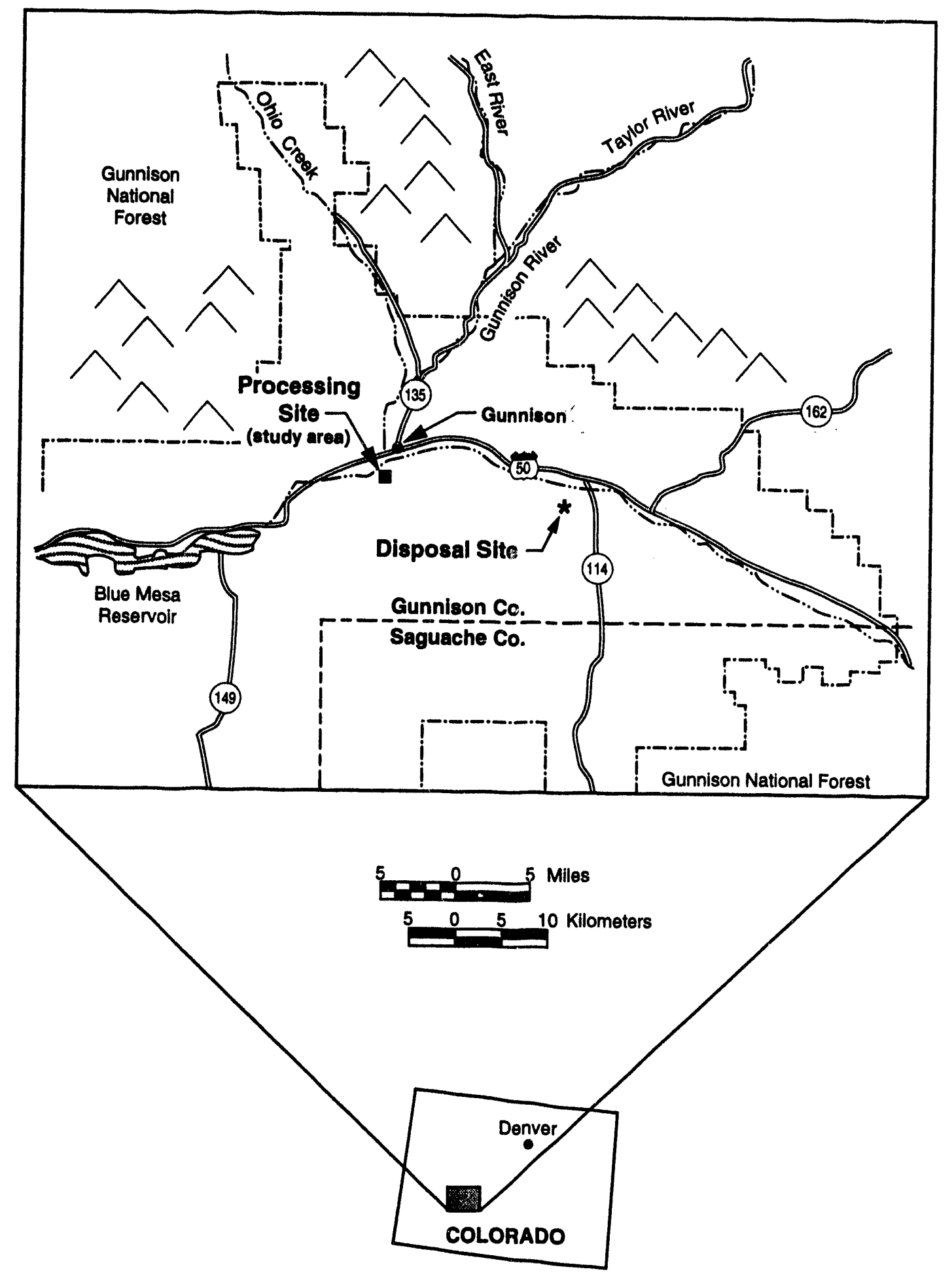

FIGURE 1.1

REGIONAL LOCATION MAP 

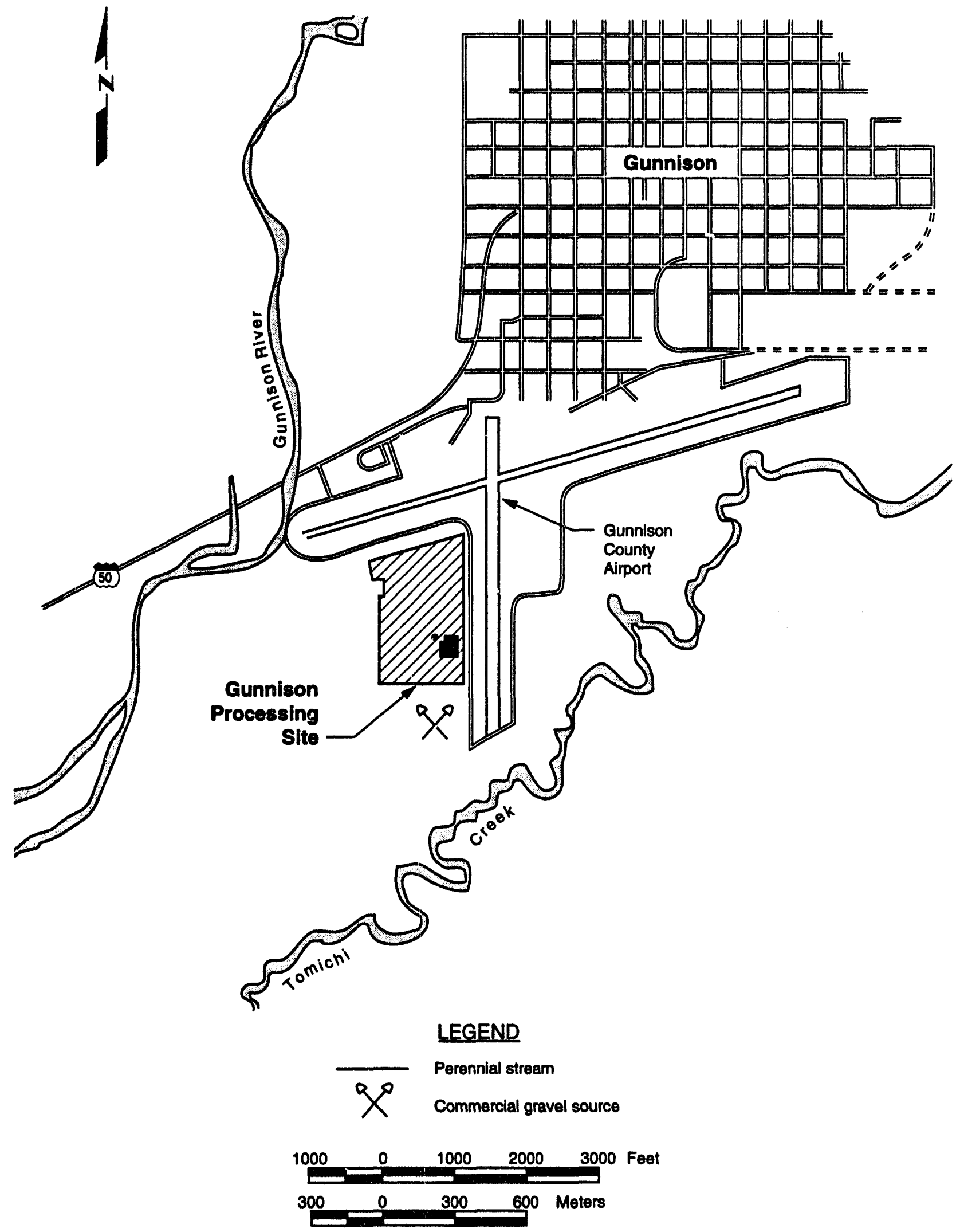

FIGURE 1.2

LOCATION OF THE PROCESSING SITE AT GUNNISON, COLORADO 


\subsection{MILLING HISTORY AND PROCESSES}

The mill at Gunnison operated from 1958 until 1962. During this time, approximately 540,000 dry tons (490,000 metric tons) of ore, averaging 0.15 percent uranium oxide $\left(\mathrm{U}_{3} \mathrm{O}_{8}\right)$, was processed. Ground ore was oxidized and acid leached using sodium chlorate and sulfuric acid. After leaching, the pregnant solution was washed repeatedly and the solids were slurried into the tailings pile. Pregnant solution was then treated with di (2-ethylhexyl) phosphoric acid (EHPA) solvent to extract the uranium. Sodium carbonate was then used to strip the uranium from the solvent. Precipitation of uranium was accomplished by acidifying to decompose the carbonate and then raising the $\mathrm{pH}$ to precipitate yellow cake.

\subsection{TAILINGS}

As a result of this process, tailings pore fluids are acidic and contain elevated concentrations of residual metals (including uranium), metalloids, and sulfate. The resulting tailings solids and pore fluids were slurried onto the outcrop of the alluvial material, forming a pile that is approximately $1180 \mathrm{ft}(360 \mathrm{~m})$ wide, $1440 \mathrm{ft}(440 \mathrm{~m})$ long, with an average depth of $13 \mathrm{ft}(4 \mathrm{~m})$. Within the pile, the tailings materials consist of interlayered and intermixed sands and slimes that directly overlie cobbly alluvial material. The slime layers are generally thicker and more extensive around the perimeter of the pile.

\subsection{HYDROGEOLOGY AND HYDROCHEMISTRY OF THE ALLUVIAL AQUIFER}

The upper-most aquifer at the site and the surrounding area occurs in recent alluvial floodplain and terrace deposits associated with the Gunnison River and Tomichi Creek (DOE, 1992). This alluvial aquifer is generally unconfined although silt and clay layers may create semiconfined conditions with increasing depth in the alluvium. The average linear ground water velocity in the alluvial aquifer is estimated to be 270 feet/year $\left(4.3 \times 10^{-4} \mathrm{~cm} / \mathrm{s}\right)$ (DOE, 1992).

Contaminants such as sulfate, uranium, manganese, and iron are present at elevated concentrations in the alluvial aquifer underneath and adjacent to the tailings pile. However, elevated levels of the transition metal contaminants do not extend for significant distances downgradient of the tailings pile. Once introduced into the alkaline ground water typical of the alluvial aquifer at the Gunnison processing site, sulfate and uranium behave as relatively conservative (mobile) constituents. Uranium is the primary constituent of environmental concern at this site and is present at concentrations above background in ground water $8000 \mathrm{ft}(2400 \mathrm{~m})$ downgradient from the tailings pile (Figure 1.3). 


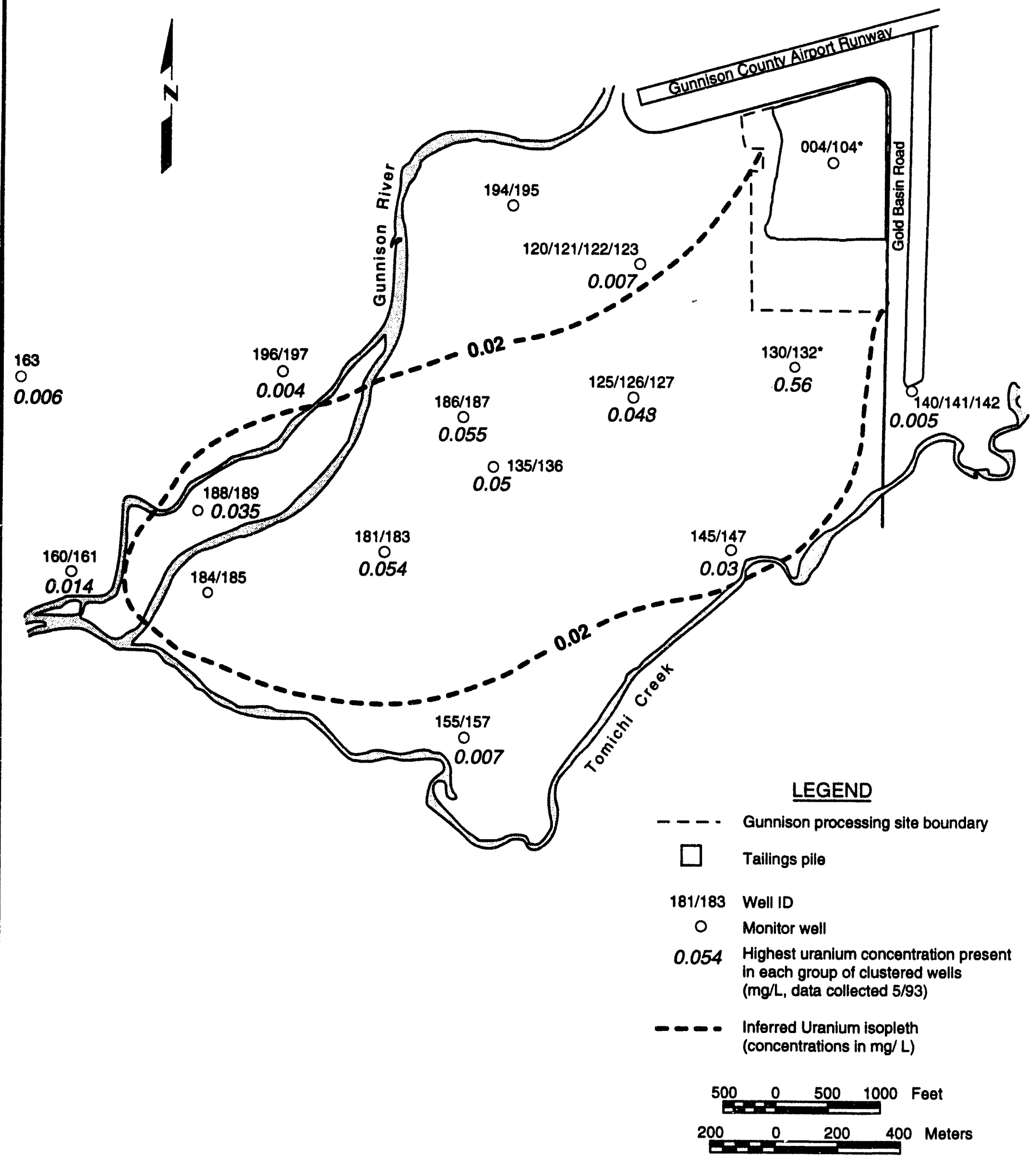

FIGURE 1.3

APPROXIMATE EXTENT OF URANIUM CONTAMINATION, GUNNISON PROCESSING SITE, GUNNISON, COLORADO 


\subsection{OBJECTIVES AND APPROACH}

The primary objective of this study was to evaluate the potential of the Gunnison subtailings sediments to act as a secondary source of ground water contamination after removal of the tailings of Ra-226 and Th-230 contaminated subpile sediment.

The following assumptions were used in designing the experimental part of this study: 1) only the tailings and none of the subpile sediments are removed during surface remediation; and 2) the water table at this site rises 3 to $6 \mathrm{ft}(1$ to $1.8 \mathrm{~m})$ and saturates the entire subpile section for an extended period of time. Although neither of these assumed events are likely to occur, their use allows us to evaluate the worst case potential for the subpile sediments to behave as a future source of groundwater contamination.

In November 1992, the technical assistance contractor (TAC) sampled sediment from three test pits installed through the tailings into the subpile sediments and from two test pits installed through off-site background sediments. The physical and chemical characteristics of the contaminated sediments collected from the three on-site test pits were compared to each other and to the vackground sediments collected using several laboratory and analytical procedures (for example, batch tests and column tests). These comparisons allowed us to answer the following questions:

- What are the concentrations and relative vertical distributions of the contaminants in the subpile sediments compared to background sediments?

- What are the hazardous const: :uents that may be mobilized from the subpile sediments, potentially producing a secondary source of ground water contamination once the surface is cleaned up?

- What are the chemical conditions that induce mobility or immobility of the contaminants in the subpile sediments?

- What remediation steps can be taken to reduce any future impact of the subpile sediments as a source of ground water contamination? 


\subsection{SAMPLE COLLECTION AND PREPARATION PROCEDURES}

\subsection{SAMPLING LOCATIONS}

Three test pits were excavated through the tailings pile (numbers 19, 20, and 22, Figure 3.1) and two background test pits (numbers 21 and 23, Figure 3.1) were excavated into the alluvial aquifer at the Gunnison, Colorado, UMTRA Project site. Descriptive lithologic logs for these 5 test pits are provided in Attachment A. The other test pit locations shown were part of the cobbles-tofines evaluation program.

The on-site test pit locations for this study were selected based on the assumption that the most highly contaminated foundation soils would generally underlie thick sections of tailings or sections of tailings with highly contaminated pore water. This determination was made by reviewing a tailings isopachous map and tailings pore water contaminant isopleth maps. The contaminant isopleth maps were generated with chemical data from 15 lysimeters completed into the lower part of the tailings and distributed throughout the tailings pile. Specific reasons for selecting on-site test pit locations were as follows:

- Test pits 20 and 22 were selected to sample foundation soils where tailings were thickest or where the highest concentrations of soluble metals had been measured in the tailings pore fluid.

- Test pit 19 was selected to test the area with the highest radionuclide content, based on radium activities measured in lysimeter tailings pore fluid samples.

The two background test pit locations (21 and 23 in Figure 3.1 ) were selected in areas uncontaminated by tailings leachate. Background sediments were collected to constrain the premilling chemistry of the subpile sediments. Once the background chemistry was established, the extent of contamination from the downward migration of low-pH tailings leachate into the subpile sediments taken from pits 19,20 , and 22 could be defined.

The location for background test pit 21 selected, in part, on the basis of its proximity to shallow background monitor well 002. Ground water from this monitor well was used as the stock leachate solution in the batch and column tests that were performed.

\subsection{SEDIMENT SAMPLING AND PROCESSING PROCEDURES}

Background sediments from pits 21 and 23 were sampled at $1-$ to 2-ft $10.3-$ to 0.6-m) intervals from a depth of $2 \mathrm{ft}(0.6 \mathrm{~m})$ to a depth of $6 \mathrm{fo} 7 \mathrm{ft}(1.8$ to $2.0 \mathrm{~m}$ ) below land surface. Although a sample of the overlying tailings was collected from each of the three pits located on the tailings pile, the remaining samples were typically collected at $1-\mathrm{ft}(0.3-\mathrm{m})$ intervals below the 

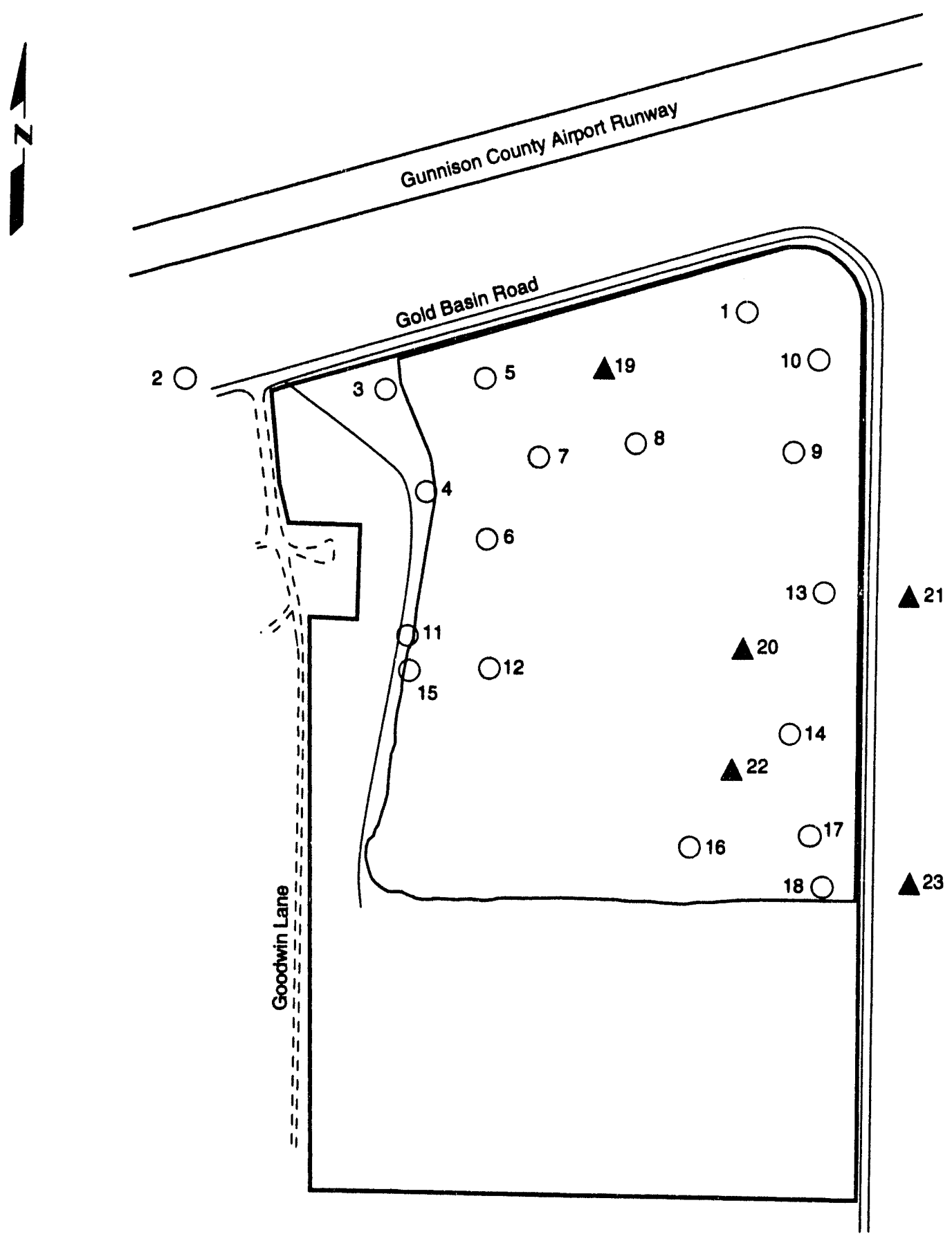

\section{LEGEND}

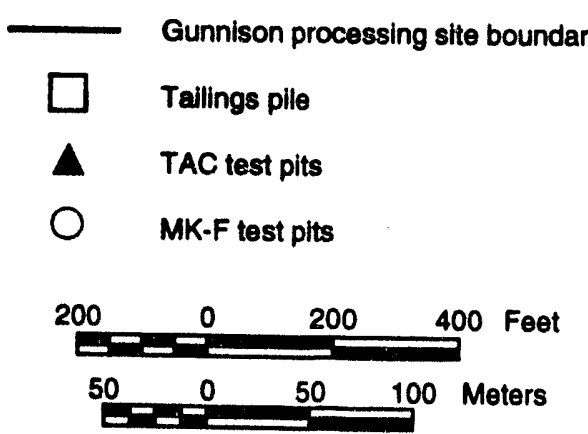

\section{FIGURE 3.1 \\ TAC TEST PIT LOCATIONS MAP GUNNISON PROCESSING SITE, COLORADO}


tailings/subsoil interface (specifically, at average depths of 0.5 to $2.5 \mathrm{ft} 10.15$ to $0.75 \mathrm{~m})$ in pit 20; of 1.5 to $5.5 \mathrm{ft}(0.5$ to $1.7 \mathrm{~m})$ in pit 19 ; and of 0.5 to $6.5 \mathrm{ft}$ $(0.15$ to $2.0 \mathrm{~m})$ in pit 22$)$.

All samples were double bagged in clean plastic bags and sealed in 5-gallon (19-liter) aluminum cans for transport to the TAC hydrochemistry facility in Albuquerque. Because of the abundance of large cobbles in the alluvial sediment at Gunnison, samples collected for laboratory analysis were unavoidably biased toward pebble-sized and finer materials. At the hydrochemistry sample preparation facility, all samples were air-dried and screened with a \#4 $(4.76 \mathrm{~mm})$ screen. The coarse- and fine-grained fractions of this sediment were bagged separately, weighed, and stored for future use in analytical or experimental procedures. 


\subsection{PHYSICAL AND MINERALOGICAL CHARACTERIZATION}

Despite the effects of the sampling bias discussed above, screening of all the sediment samples with a $\# 4(4.76 \mathrm{~mm})$ screen demonstrated that approximately 60 percent by weight $(w t \%)$ of the sediment collected :vas coarser than a \#4 screen (Table 4.1). Without the sampling bias, coarser material would have made up significantly more than 60 percent of the bulk sediment.

One sample of the finer-grained sediment (< \#4 mesh) from each test pit was selected for more extensive grain-size, mineralogical, and selected geochemical analysis by a subcontracting laboratory. A summary of these data is shown in Table 4.2.

The results of the grain size analysis (Tables 4.1 and 4.2$)$ indicate that the bulk $(-85$ to $95 \mathrm{wt} \%)$ of these finer-grained sediments is coarser than medium-grained sand $(0.042 \mathrm{~mm}$ ). An X-ray diffraction (XRD) analysis of these samples indicates that the mineralogy of the selected sediments from all five test pits is dominated by quartz and feldspar (62 to $77 \mathrm{wt} \%$ ) (Table 4.3). Gypsum is a significant component of the sediment from two (19 and 22) of the three on-site test pits dug through thie tailings (Table 4.3). The sediments from the two background test pits and subpile pit 20 had insufficient gypsum to be detected by XRD. 


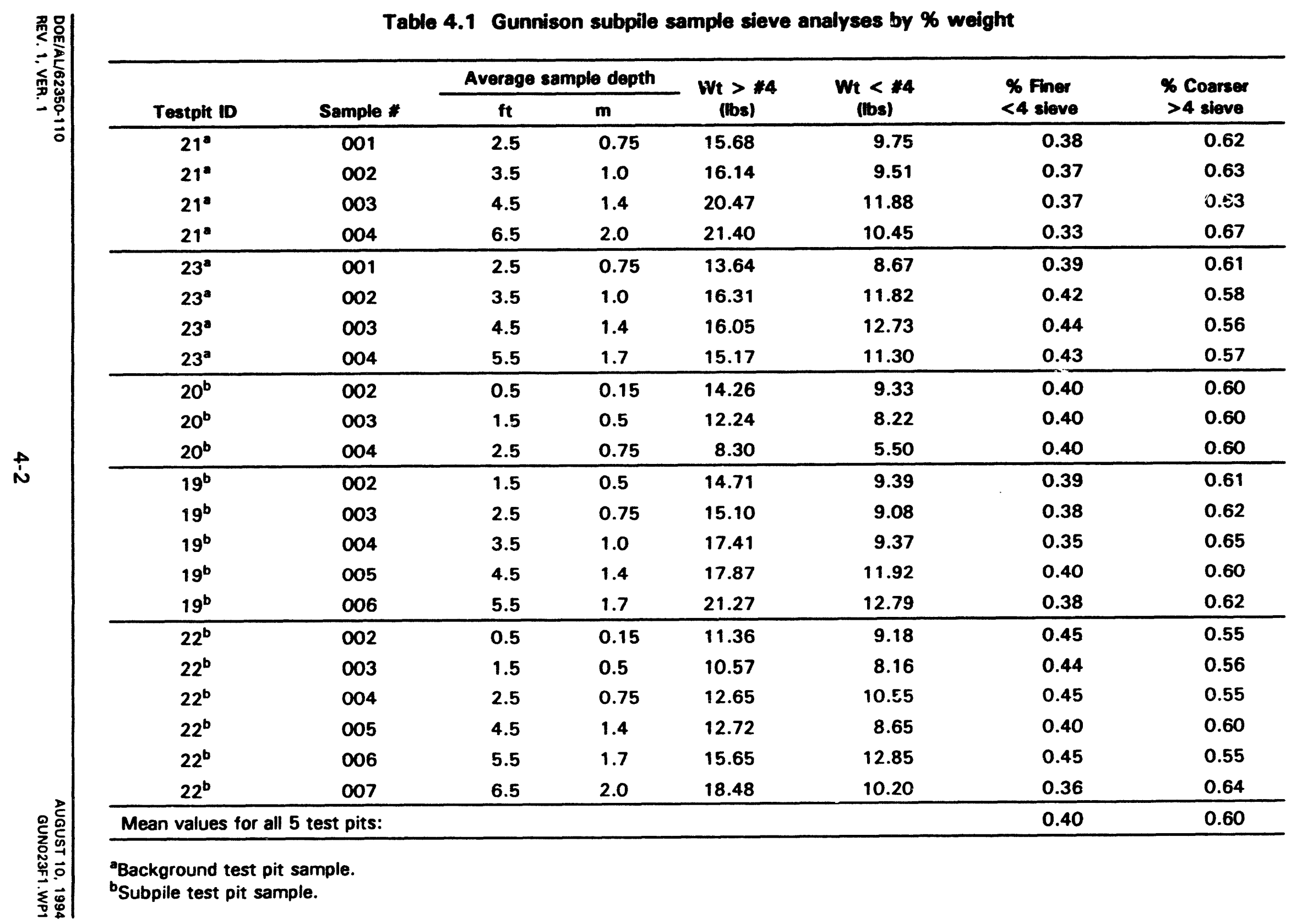




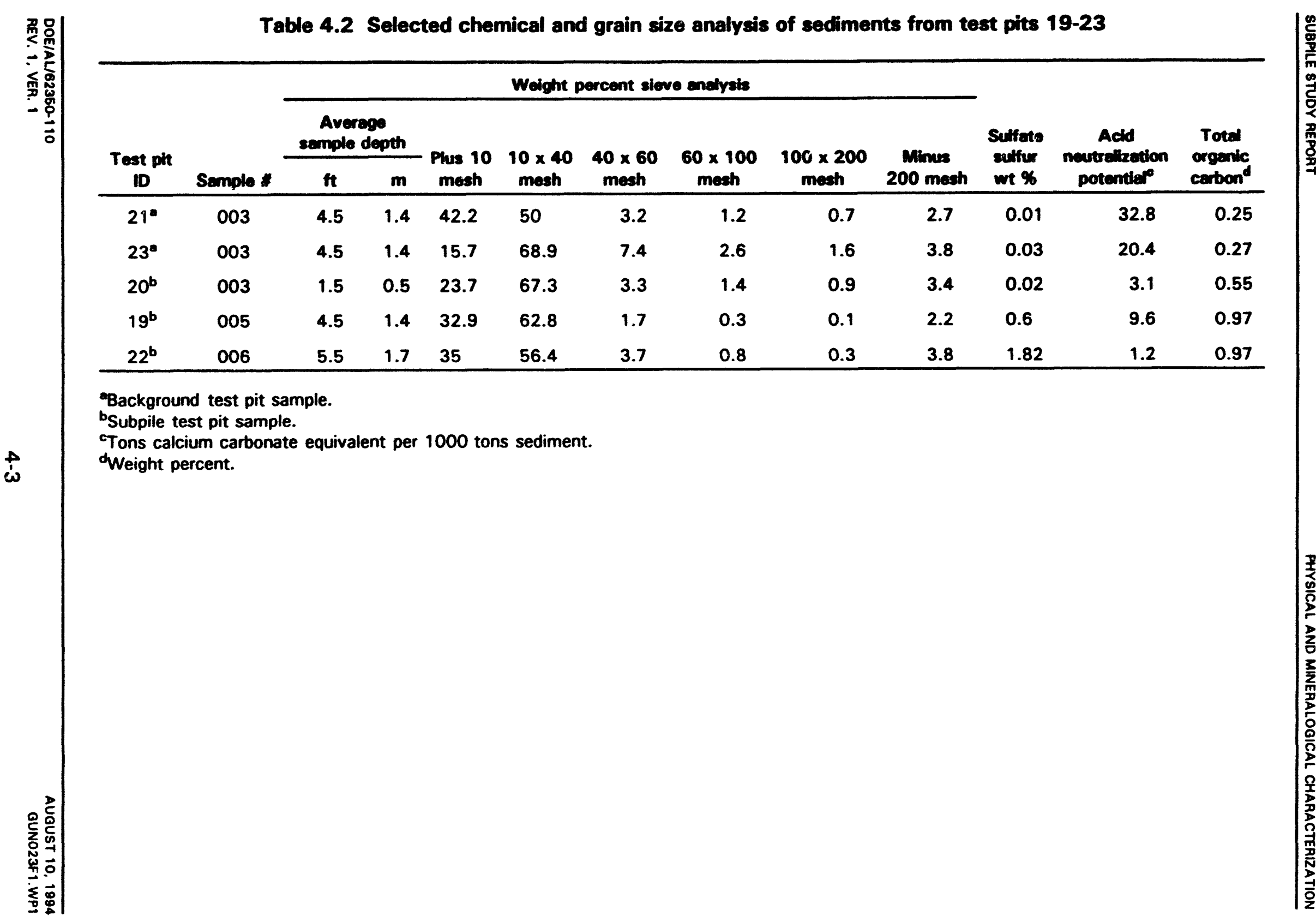


Table 4.3 XRD analysis of subpile and background sediments in approximate wt\%

\begin{tabular}{|c|c|c|c|c|c|}
\hline Bulk mineralogy & $\begin{array}{l}\text { Pit 21" } \\
\text { (wt\%) }\end{array}$ & $\begin{array}{l}\text { Pit 23* } \\
\text { (wt\%) }\end{array}$ & $\begin{array}{l}\text { Pit 20b } \\
\text { (wt\%) }\end{array}$ & $\begin{array}{l}\text { Pit 19b } \\
(w+\%)\end{array}$ & $\begin{array}{l}\text { Pit } 22^{b} \\
\text { (wt\%) }\end{array}$ \\
\hline Quartz & 34 & 35 & 36 & 35 & 30 \\
\hline Plagioclase feldspar & 28 & 30 & 25 & 24 & 17 \\
\hline K-feldspar & 13 & 12 & 12 & 13 & 15 \\
\hline Mica/illite & 10 & 10 & 10 & 12 & $<10$ \\
\hline Chlorite & $<5$ & $<5$ & 5 & $<5$ & $<5$ \\
\hline Clinoamphibole & $<5$ & $<5$ & $<5$ & $<3$ & $<5$ \\
\hline Calcite & $<3$ & -- & -- &.- & -. \\
\hline Dolomite & $<3$ & $<3$ & .. & -- & -. \\
\hline Gypsum & -. & -. & -. & 6 & 18 \\
\hline Smectite & .. & -- & $<5 ?$ & $-\cdot$ & .. \\
\hline Unidentified & $<5$ & $<5$ & $<5$ & $<5$ & $<5$ \\
\hline
\end{tabular}

Background test pits.

bSubpile test pits. 


\subsection{SOIL CHEMISTRY}

\subsection{RELATIVE SOIL ALKALINITY AND ACIDITY}

The abundant gypsum in the sediments of subpiles 19 and 22 was most likely generated during the neutralization of infiltrating sulfate-rich, acidic tailings pore water by calcium carbonate $\left(\mathrm{CaCO}_{3}\right)$ originally present in the sediments. Some of the subpile sediments from all three on-site test pits have much lower acidneutralization potentials than do the background sediments (see Table 4.2). Soil acidity measurements indicate that many of the shallow sediments from the onsite test pits would acidify typical background ground water (Attachment B). These data further support the assumption that relatively large volumes of acidic leachate have migrated into the subpile sediments from the overlying tailings. Therefore, despite the scarcity of gypsum in the sediment from pit 20 , significant amounts of $\mathrm{CaCO}_{3}$ were dissolved by infiltrating acidic tailings pore water in the sediment of all three subpile test pits.

Although only a minor amount of gypsum is present in the sediments of pit 20 , it may have previously been much more abundant in these sediments than is currently the case. The gypsum generated by the acid-neutralization reactions may have subsequently been flushed from these sediments (in the vicinity of pit $20)$ by the influx of relatively large volumes of gypsum-undersaturated water. Conversely, the abundant gypsum retained in the sediment of pits 19 and 22 suggests that large volumes of nonacidic, gypsum-undersaturated water has not passed through these subpile sediments.

\subsection{EPA METHOD 3050 AND TOTAL SOIL DIGESTION RESULTS}

Two to four sediment samples from each test pit were submitted to a subcontract analytical laboratory for a strong mineral acid digestion procedure (EPA method 3050). This procedure dissolves almost all non-silicate phases in sediment. The resulting method 3050 solutions were analyzed for a select group of indicator and contaminant elements (Table 5.1). In addition, total soil dissolution concentrations of Th-230, Ra-226, and Ra-228 were determined for aliquots of all of the samples collected from these pits (Table 5.2).

Some of the subpile sediments are significantly enriched in many constituents relative to sediments from the background pits (Figure 5.1). Manganese concentrations, however, appear to be generally lower in the subpile sediments than in the background sediments. The concentrations of vanadium and cadmium are comparable in the background and on-site test plots (Table 5.1); however, this comparison is based on only one analysis per test pit.

Scatter plots of concentrations found for selected constituents, versus sample depth, indicate that there are significant variations in some contaminant concentrations between the three subpile test pits (Figure 5.1). For example, test pit 22 has significantly higher levels of arsenic, molybdenum, and Th-230 


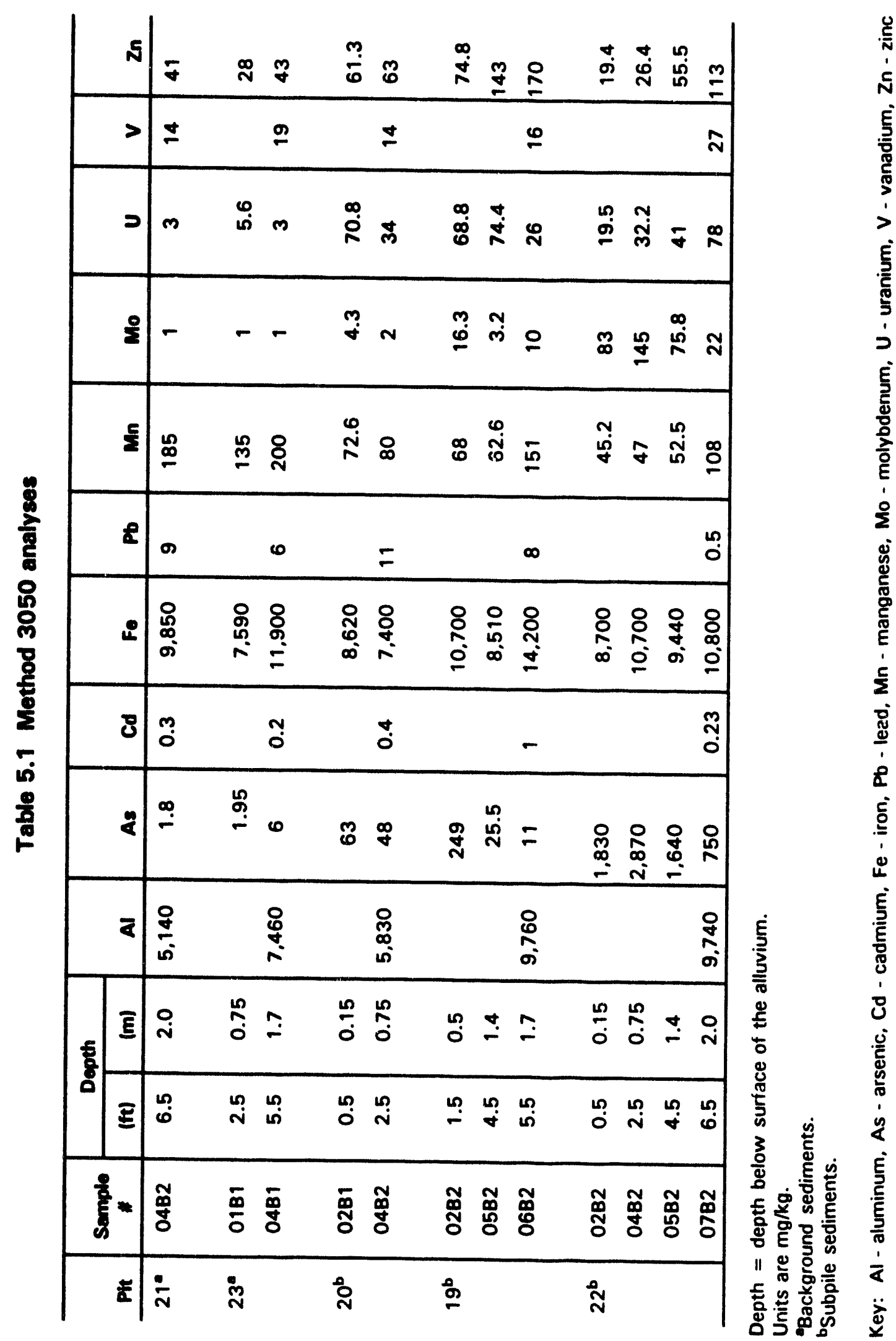




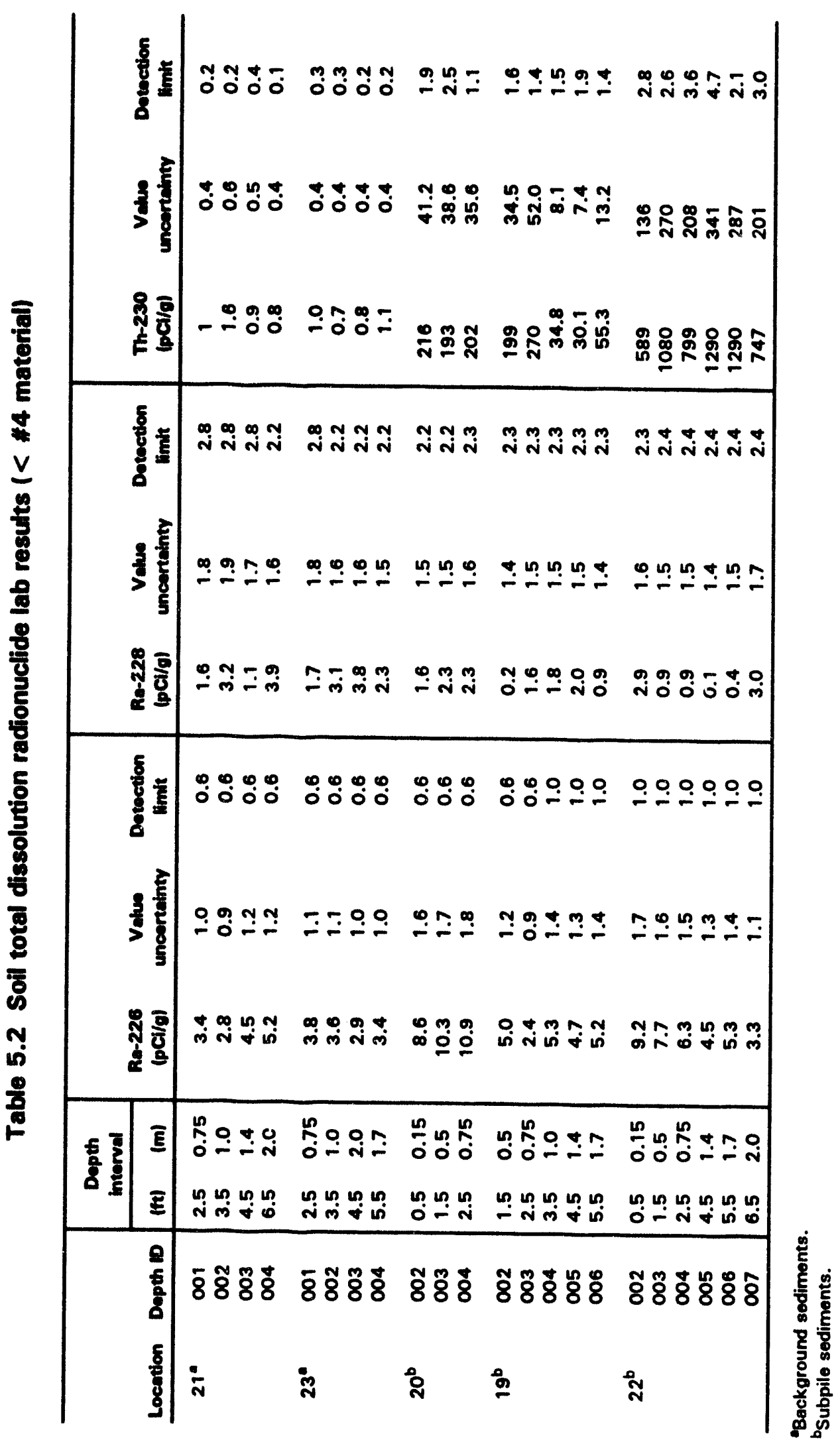



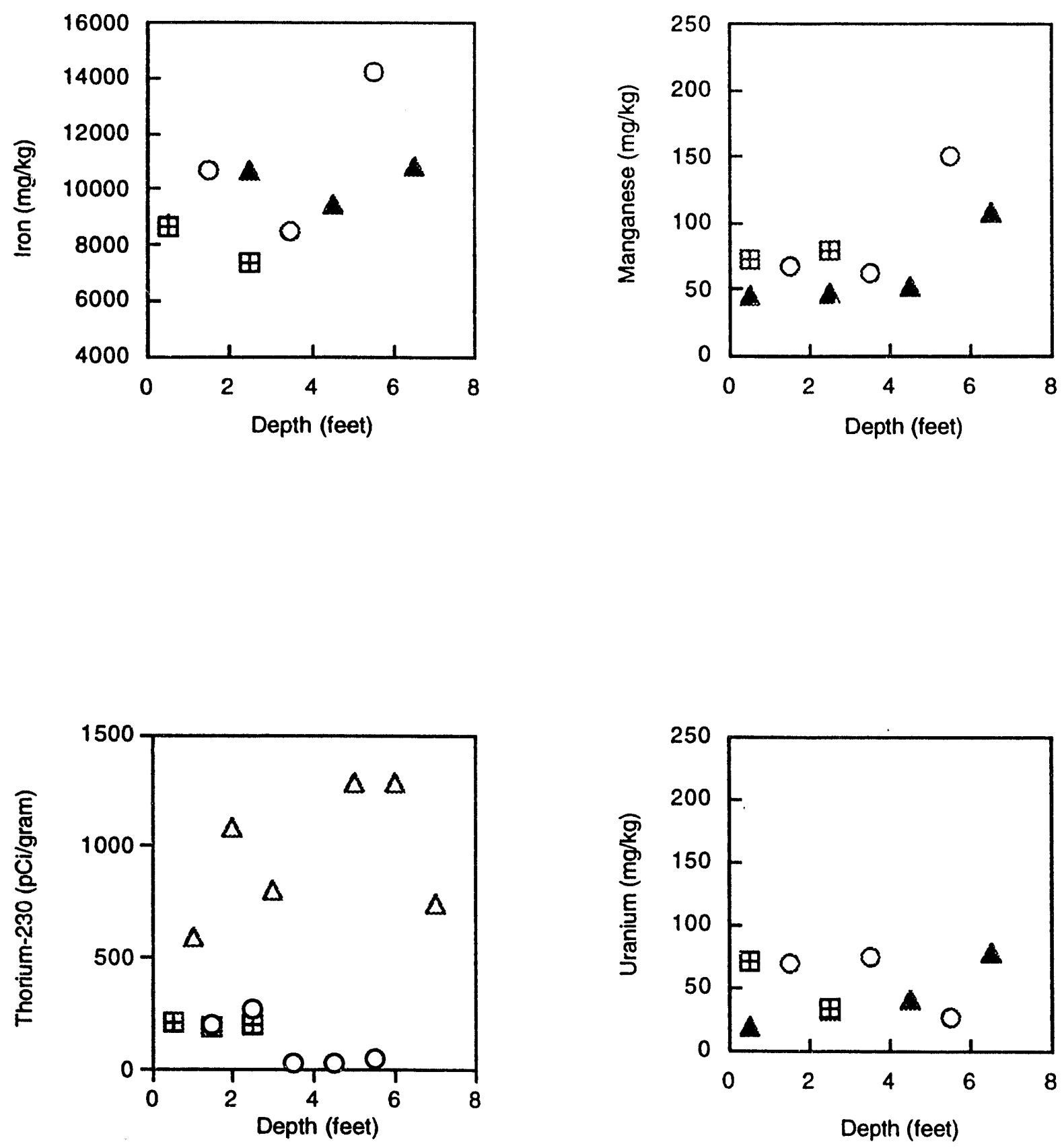

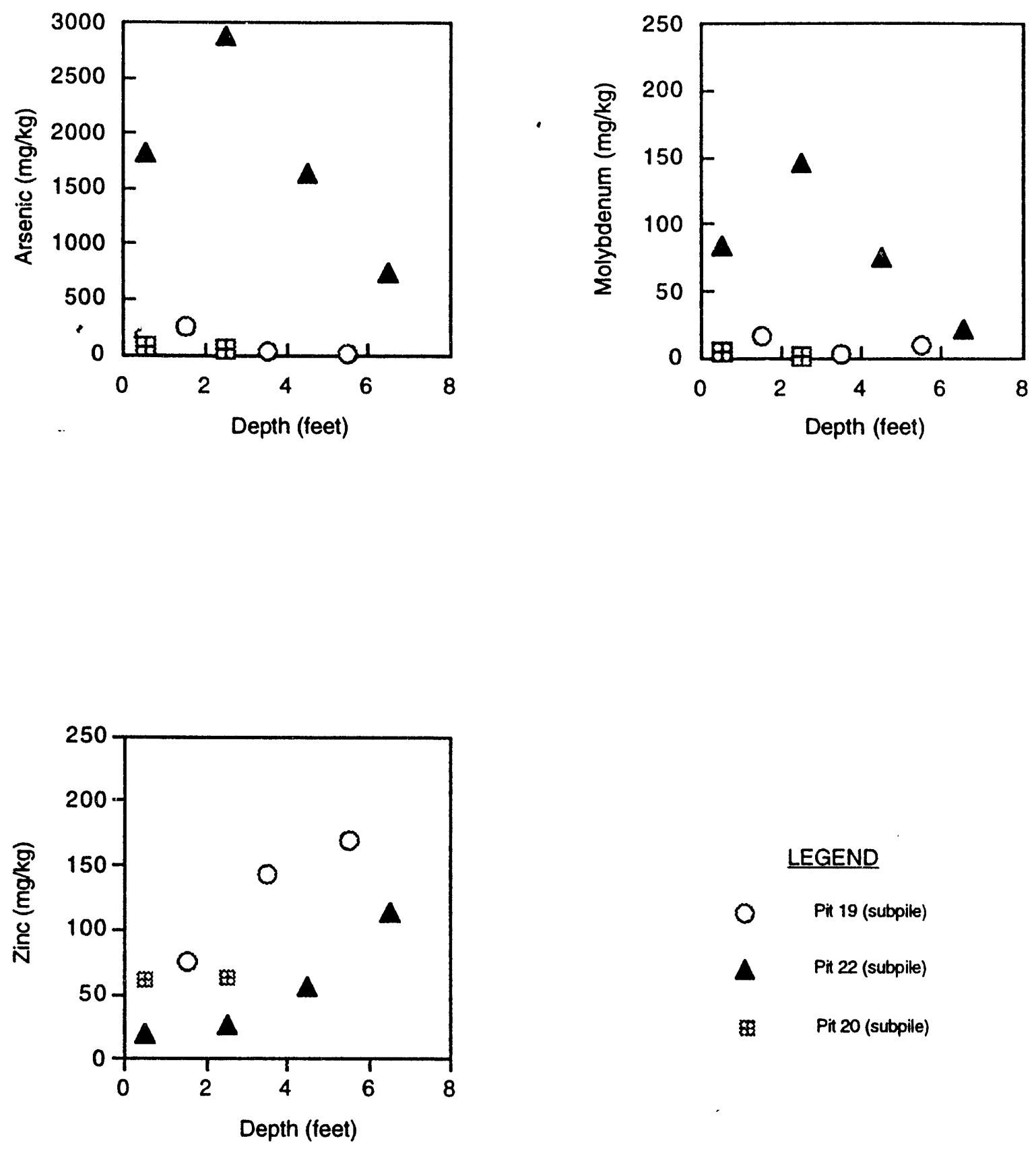

FIGURE 5.1

METHOD 3050 METALS CONCENTRATIONS AND TOTAL DISSOLUTION THORIUM-230 ACTIVITY VERSUS SAMPLE DEPTH BELOW TAILINGS/ALLUVIUM INTERFACE 
than do the other on-site test pits (19 and 20) (Figure 5.1). Zinc concentrations are much higher in test pit 19, while uranium concentrations are comparable in all three subpile test pits.

The method 3050 and total dissolution data alone do not allow us to evaluate the potential mobility of these constituents under current or future environmental conditions. Due to the extreme intensity of the digestion techniques used, essentially all of the hazardous constituents present in these soils were solubilized, irrespective of their origin and current mobility under in situ conditions. Less chemically intensive tests are needed to determine the concentrations of these constituents that are likely to be remobilized under the less acidic-to-alkaline conditions that will occur in the subpile sediments once the tailings are removed. More realistic estimates of future contaminant solubility and mobility at Gunnison can be determined from the batch test and column test data presented below.

\subsection{BATCH TESTS}

One sample of tailings from each of the three on-site test pits, as well as all the fine fractions (< \#4 mesh) of the subpile samples collected from all five test pits, were subjected to a batch test procedure.

The batch tests were performed using a modification of the American Society for Testing and Materials (ASTM) method 4319 (ASTM, 1984). Each batch test consisted of placing $\mathbf{2 0 0}$ grams of tailings or sediment in a plastic Erlenmeyer flask, along with 800 grams of Gunnison background water (acidified with sulfuric acid $\left[\mathrm{H}_{2} \mathrm{SO}_{4}\right]$ to a pH of approximately 2.4 to simulate a ground water/tailings pore fluid mixture). The ground water used as the leachate in these tests was collected from background monitor well 002 . The composition of this ground water before and after acidification is given in Table 5.3.

The batch test mixtures described above were agitated for 1 hour twice a day for 3 days with a wrist-action shaker equipped to accommodate four 1000-milliliter $(\mathrm{mL})$ Erlenmeyer flasks. After a 72-hour reaction time elapsed, the solution was decanted, filtered with a 0.45 -micrometer $(u \mathrm{~m})$ filter, and preserved according to the Albuquerque Standard Operations Manual (JEG, n.d.). Conductivity and $\mathrm{pH}$ were measured on unfiltered aliquots of each of these leachate solutions (Table 5.4). Filtered and preserved samples were then submitted to a subcontracting laboratory for chemical analysis. The constituents selected for analysis included aluminum, arsenic, cadmium, iron, lead, manganese, molybdenum, vanadium, zinc, and uranium (Table 5.4). The data for the first samples $(001)$ listed in Table 5.4 for on-site pits 19, 20, and 22 represent batch test results for actual tailings materials from these pits. Sample numbers 002 or greater from the test pits through the tailings represent samples of the subpile sediments.

The concentrations of most metals are significantly higher, and the equilibrium $\mathrm{pH}$ much lower, in the tailings batch test solutions than in any of the subpile 
Table 5.3 Parameters and analytical values for the master solution used in the column tests and acidified solution used in the batch tests for the Gunnison subpile study

\begin{tabular}{|c|c|c|c|}
\hline Parameter & $\begin{array}{c}\text { Master groundwater solution } \\
(\mathrm{mg} / \mathrm{L})\end{array}$ & $\begin{array}{c}\text { Acidified botch solution } \\
\text { (mg/L) }\end{array}$ & $\begin{array}{l}\text { Detection limits } \\
\text { (mg/L) }\end{array}$ \\
\hline Aluminum & $<0.05$ & $<0.05$ & 0.05 \\
\hline Alkalinity & 233 & NA & 1 \\
\hline Arsenic & $<0.005$ & $<0.005$ & 0.005 \\
\hline Barium & 0.12 & 0.13 & 0.01 \\
\hline Calcium & 78.8 & 86 & 0.5 \\
\hline Cadmium & $<0.001$ & NA & 0.001 \\
\hline Chlorine & 6.9 & 6.4 & 0.5 \\
\hline Chromium & $<0.01$ & NA & 0.01 \\
\hline Iron & $<0.03$ & $<0.03$ & 0.03 \\
\hline pH & 7.81 & 2.42 & \\
\hline Potassium & 1.97 & 2.09 & 0.01 \\
\hline Magnesium & 14.3 & 14.8 & 10.1 \\
\hline Manganese & $<0.01$ & $<0.01$ & 0.01 \\
\hline Molybdenum & $<0.01$ & $<0.09$ & 0.01 \\
\hline Sodium & 8.3 & 8.63 & 0.01 \\
\hline Nitrate & 2.6 & NA & 1.0 \\
\hline Lead & $<0.003$ & NA & 0.003 \\
\hline Antimony & $<0.003$ & $<0.003$ & 0.003 \\
\hline Selenium & $<0.005$ & NA & 0.005 \\
\hline Silica & 16.3 & 16.5 & 0.1 \\
\hline Sulfate & 33 & 573 & 10 \\
\hline Strontium & 0.24 & 1.76 & 0.01 \\
\hline TDS & 274 & 1296 & 10 \\
\hline Vanadium & $<0.01$ & $<0.01$ & 0.01 \\
\hline Lead-210 & 5.6 & NA & 0.3 \\
\hline$R a-226^{b}$ & 1.0 & NA & 0.6 \\
\hline$R a-228^{b}$ & 4.7 & NA & 2.0 \\
\hline Uranium & 0.003 & NA & 0.001 \\
\hline
\end{tabular}

"Background ground water from Gunnison monitor well 002.

bunits are in pCi/l.

NA - not analyzed. 
Table 5.4 Batch test data for

\begin{tabular}{|c|c|c|c|c|c|c|c|}
\hline \multirow[b]{2}{*}{ Test pit } & \multirow{2}{*}{$\begin{array}{l}\text { Depth } \\
\text { ID }\end{array}$} & \multicolumn{2}{|c|}{ Depth } & \multirow{2}{*}{$\begin{array}{c}\text { Sample } \\
\text { ID }\end{array}$} & \multirow{2}{*}{$\begin{array}{c}A 1 \\
m g n\end{array}$} & \multirow{2}{*}{$\begin{array}{c}\text { As } \\
\mathrm{mg} / \mathrm{L}\end{array}$} & \multirow{2}{*}{$\begin{array}{c}\mathrm{Cd} \\
\mathrm{mg} / \mathrm{L}\end{array}$} \\
\hline & & (ft) & $|m|$ & & & & \\
\hline \multirow[t]{4}{*}{$21^{\circ}$} & 001 & 2.5 & 0.75 & 0182 & $<0.05$ & $<0.005$ & $<0.001$ \\
\hline & 002 & 3.5 & 1.0 & O2B2 & $<0.05$ & $<0.005$ & $<0.001$ \\
\hline & 003 & 4.5 & 1.4 & O3B2 & $<0.05$ & $<0.005$ & $<0.001$ \\
\hline & 004 & 6.5 & 2.0 & 0482 & $<0.05$ & $<0.005$ & $<0.001$ \\
\hline \multirow[t]{4}{*}{$23^{\circ}$} & 001 & 2.5 & 0.75 & 0181 & $<0.05$ & $<0.005$ & $<0.001$ \\
\hline & 002 & 3.5 & 1.0 & $02 B 1$ & $<0.05$ & $<0.005$ & $<0.001$ \\
\hline & 003 & 4.5 & 1.4 & O3B1 & $<0.05$ & $<0.005$ & $<0.001$ \\
\hline & 004 & 5.5 & 1.7 & $04 B 1$ & $<0.05$ & $<0.005$ & $<0.001$ \\
\hline \multirow[t]{7}{*}{$20^{b}$} & 001 & Tailings & & $01 B 2$ & 468 & 1.6 & 0.23 \\
\hline & 002 & 0.5 & 0.15 & 0281 & 45.8 & $<0.05$ & 0.03 \\
\hline & 002 & 0.5 & 0.15 & $02 C_{2}$ & 49.8 & $<0.005$ & 0.03 \\
\hline & 002 & 0.5 & 0.15 & $02 \mathrm{D} 2$ & 51.5 & $<0.005$ & 0.03 \\
\hline & 003 & 1.5 & 0.5 & O3B1 & 39.9 & $<0.005$ & $<0.05$ \\
\hline & 003 & 1.5 & 0.5 & 0302 & 44.8 & $<0.03$ & $<0.05$ \\
\hline & 004 & 2.5 & 0.75 & $04 B 2$ & 53.0 & $<0.03$ & 0.03 \\
\hline \multirow[t]{8}{*}{$19^{b}$} & 001 & Tailings & & $01 B 2$ & 442 & 2.0 & 0.23 \\
\hline & 002 & 1.5 & 0.5 & 0282 & 96.0 & 0.9 & 0.1 \\
\hline & 002 & 1.5 & 0.5 & $02 C_{2}$ & 90.5 & 0.9 & 0.2 \\
\hline & 002 & 1.5 & 0.5 & O2D2 & 107 & 1.1 & 0.2 \\
\hline & 003 & 2.5 & 0.75 & 0382 & 68.0 & 0.14 & $<0.1$ \\
\hline & 004 & 3.5 & 1.0 & $04 B 2$ & 3.73 & 0.023 & $<0.05$ \\
\hline & 005 & 4.5 & 1.4 & $05 B 2$ & $<0.05$ & $<0.005$ & 0.01 \\
\hline & 006 & 5.5 & 1.7 & O6B2 & $<0.05$ & $<0.005$ & $<0.01$ \\
\hline \multirow[t]{7}{*}{$22^{b}$} & 001 & Tailings & & $01 B 2$ & 58.6 & 1.3 & $<0.01$ \\
\hline & 002 & 0.5 & 0.15 & $02 \mathrm{~B} 2$ & 109 & 1.20 & 0.040 \\
\hline & 003 & 1.5 & 0.5 & O3B2 & 79.5 & 0.91 & 0.029 \\
\hline & 004 & 2.5 & 0.75 & 0482 & 77.0 & 0.69 & 0.035 \\
\hline & 005 & 4.5 & 1.4 & 0582 & 7.38 & 0.26 & 0.044 \\
\hline & 006 & 5.5 & 1.7 & 0682 & 2.05 & 0.19 & 0.05 \\
\hline & 007 & 6.5 & 2.0 & $07 B 2$ & 0.06 & 0.04 & 0.02 \\
\hline
\end{tabular}

Samples $02 B 1-02 D 2$ from test pit 20 and $02 B 2-02 D 2$ from test pit 19 are triplicate samples.

Sample 01B2 for test pits 20,19 , and 22 is of tailings material.

Background sediments.

bSubpile sediments.

Key: Al - aluminum, As - arsenic, Cd-cadmium, $\mathrm{Fe}$ - iron, $\mathrm{Pb}$ - lead, $\mathrm{Mn}$ - manganese, Mo - molybden 
\#4 mesh sample material, acid leach $(=2.4 \mathrm{pH})$

\begin{tabular}{|c|c|c|c|c|c|c|c|c|}
\hline $\begin{array}{c}\mathrm{Fe} \\
\mathrm{mg} n\end{array}$ & $\begin{array}{c}\mathrm{Pb} \\
\mathrm{mg} / \mathrm{L}\end{array}$ & $\operatorname{Mn}_{m g n}$ & $\begin{array}{c}\mathrm{Mo} \\
\mathrm{mg} / \mathrm{L}\end{array}$ & $\underset{m g n}{V}$ & $\begin{array}{c}2 n \\
m g n\end{array}$ & $\underset{m g h}{U}$ & pH & $\underset{\mu \mathrm{sc} / \mathrm{cm}}{E c}$ \\
\hline$<0.03$ & $<0.003$ & 0.28 & $<0.01$ & $<0.01$ & 0.03 & 0.007 & 6.79 & 1630 \\
\hline$<0.03$ & $<0.003$ & 0.20 & $<0.01$ & $<0.01$ & 0.041 & 0.005 & 6.69 & 1680 \\
\hline$<0.03$ & $<0.003$ & 0.22 & $<0.01$ & $<0.01$ & 0.012 & 0.003 & 6.71 & 1510 \\
\hline$<0.03$ & $<0.003$ & 0.22 & $<0.01$ & $<0.01$ & $<0.005$ & 0.011 & 6.61 & 1320 \\
\hline$<0.03$ & $<0.003$ & 0.44 & $<0.01$ & $<0.01$ & 0.020 & 0.023 & 6.48 & 1630 \\
\hline$<0.03$ & $<0.003$ & 0.62 & $<0.01$ & $<0.01$ & 0.008 & 0.004 & 6.43 & 1450 \\
\hline$<0.03$ & $<0.003$ & 0.41 & $<0.01$ & $<0.01$ & 0.017 & 0.010 & 6.62 & 1510 \\
\hline$<0.03$ & $<0.003$ & 0.56 & $<0.01$ & $<0.01$ & 0.008 & 0.003 & 6.50 & 1470 \\
\hline 795 & $\quad 0.004$ & 5.75 & 0.25 & 0.70 & 20.1 & 12.9 & 2.45 & 6230 \\
\hline 3.92 & 0.009 & 0.35 & $<0.01$ & $<0.05$ & 0.742 & 2.22 & 3.86 & 1390 \\
\hline 2.91 & 0.012 & 0.31 & $<0.01$ & $<0.05$ & 0.635 & 2.57 & 3.85 & 1350 \\
\hline 3.41 & 0.015 & 0.36 & $<0.01$ & $<0.05$ & 0.689 & 2.67 & 3.91 & 1440 \\
\hline 6.49 & 0.006 & 0.55 & $<0.01$ & $<0.05$ & 1.76 & 1.60 & 3.92 & 1180 \\
\hline 5.08 & 0.004 & 0.50 & $<0.01$ & $<0.05$ & 1.51 & 1.79 & 3.96 & 1230 \\
\hline 3.89 & 0.007 & 0.26 & $<0.01$ & $<0.05$ & 0.821 & 2.62 & 4.09 & 1270 \\
\hline 735 & 0.010 & 14.6 & 0.70 & 0.60 & 23.4 & 11.70 & 2.34 & 6660 \\
\hline 19.4 & $<0.003$ & 1.44 & $<0.01$ & $<0.1$ & 2.43 & 2.78 & 4.06 & 2910 \\
\hline 15.2 & $<0.003$ & 1.32 & 0.01 & $<0.05$ & 2.19 & 2.45 & 3.93 & 2750 \\
\hline 15.3 & $<0.003$ & 1.28 & $<0.01$ & $<0.01$ & 2.13 & 2.59 & 3.99 & 2730 \\
\hline 4.98 & $<0.003$ & 0.82 & $<0.01$ & $<0.05$ & 1.36 & 2.07 & 4.18 & 2760 \\
\hline 0.86 & $<0.003$ & 0.78 & $<0.01$ & $<0.01$ & 0.399 & 0.398 & 4.20 & 2710 \\
\hline$<0.03$ & $<0.03$ & 0.42 & 0.02 & $<0.01$ & 0.065 & 0.063 & 6.18 & 2420 \\
\hline$<0.03$ & $<0.003$ & 0.33 & 0.08 & 0.01 & 0.018 & 0.157 & 6.57 & 1700 \\
\hline 119 & 0.8 & 0.30 & 0.33 & 0.24 & 2.49 & 1.48 & 2.31 & 6660 \\
\hline 48.0 & 0.005 & 0.68 & 0.09 & 0.10 & 0.926 & 0.985 & 3.43 & 3040 \\
\hline 21.1 & 0.012 & 0.67 & 0.08 & 0.04 & 0.952 & 0.647 & 3.28 & 2770 \\
\hline 11.9 & 0.004 & 0.58 & 0.10 & 0.02 & 1.08 & 0.525 & 3.49 & 2720 \\
\hline 3.43 & $<0.003$ & 0.69 & 0.04 & $<0.01$ & 1.59 & 0.223 & 4.26 & 2400 \\
\hline 2.14 & $<0.003$ & 0.82 & 0.04 & $<0.01$ & 2.06 & 0.100 & 4.58 & 2390 \\
\hline 0.28 & $<0.003$ & 0.49 & 0.07 & $<0.01$ & 0.171 & 0.048 & 5.43 & 2560 \\
\hline
\end{tabular}

$m, U$ - uranium, $V$ - vanadium, $Z n$ - zinc, Ec - conductivity, $\mu \mathrm{S} / \mathrm{cm}$ - millisiemens per centimeter. 
sediment batch test solutions (Table 5.4). Although the method 3050 analyses demonstrated that the "total" concentrations of some constituents remained high or even increased with depth in some subpile test pits (for example, zinc, uranium, and Th-230), the concentrations of most contaminants in the batch test solutions tended to decrease with increased sampling depth (Table 5.4). Conversely, the $\mathrm{pH}$ of the batch test solutions typically increased with depth (Figure 5.2).

The concentrations of many of the metals, particularly iron, in the solution had a well-defined inverse relationship with the increasing $\mathrm{pH}$ of the batch test solutions (Figure 5.3). Molybdenum, however, did not systematically follow this trend. In test pits 19 and 22, the concentration of molybdenum was higher in batch test solutions equilibrated with the deepest, highest $\mathrm{pH}$ sediments than in those equilibrated with some of the shallower, more acidic sediments (Figure 5.3).

Two samples of iron-hydroxide-coated pebbles from each test pit were also leached following the same procedure. An effort was made to remove silt, sand, and clay material that had loosely adhered to the pebbles. Complete removal of material other than iron and manganese hydroxides was, however, impossible.

The pebbles consisted primarily of igneous rock fragments that were insoluble under batch test conditions. Only the iron, manganese hydroxide, and the small amounts of clay coating the pebbles were soluble. Consequently, the batch test analyses of these heavily iron-stained pebbles allowed us to evaluate the importance of iron and manganese hydroxides as a source of trace constituents in the subpile sediments. The results are presented in Table 5.5.

As can be seen from Table 5.5, significant amounts of many metal constituents were solubilized from the coated pebbles during batch tests. These results indicate that iron and manganese hydroxides are significant sources of trace metals in these sediments.

\subsection{COLUMN TESTS}

Column tests using typical Gunnison alluvial background water (see Table 5.3) as a leaching agent were performed on the sediment from all five test pits. These column tests were designed to bound the potential effects on Gunnison ground water chemistry if alkaline background ground water with a $\mathrm{pH}$ above 7 were to interact with contaminated subpile sediments under saturated conditions (Figures 5.4 and 5.5). We hoped that this experiment would allow us to determine the contaminants that would be mobilized from these sediments if the water table of the alluvial system were to rise into the subpile sediments after the tailings had been removed. The two columns with background sediment were used to establish baseline conditions. 


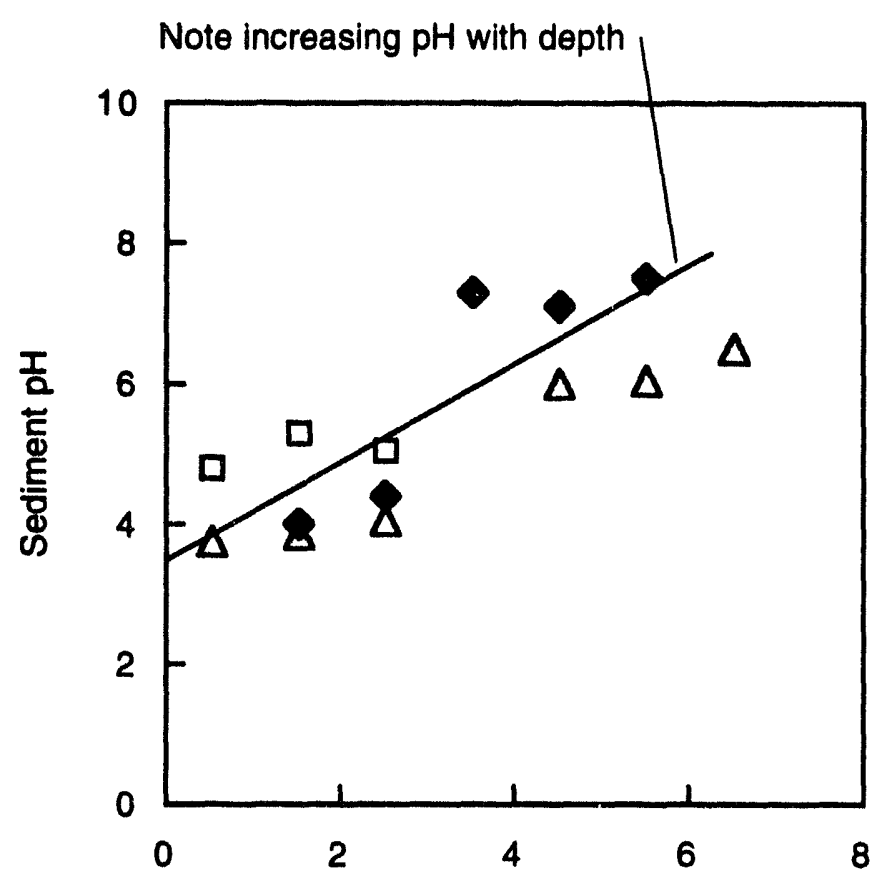

Average Sample Depth Below Tailings/Alluvium Interface

(Feet)

\section{LEGEND}

口 Pit 20 (subpile)

- Pit 19 (subpile)

$\Delta \quad$ Pit 22 (subpile)

FIGURE 5.2

SAMPLE DEPTH VERSUS FINAL PH OF BATCH TEST SOLUTIONS FOR THE ON-SITE TEST PITS 

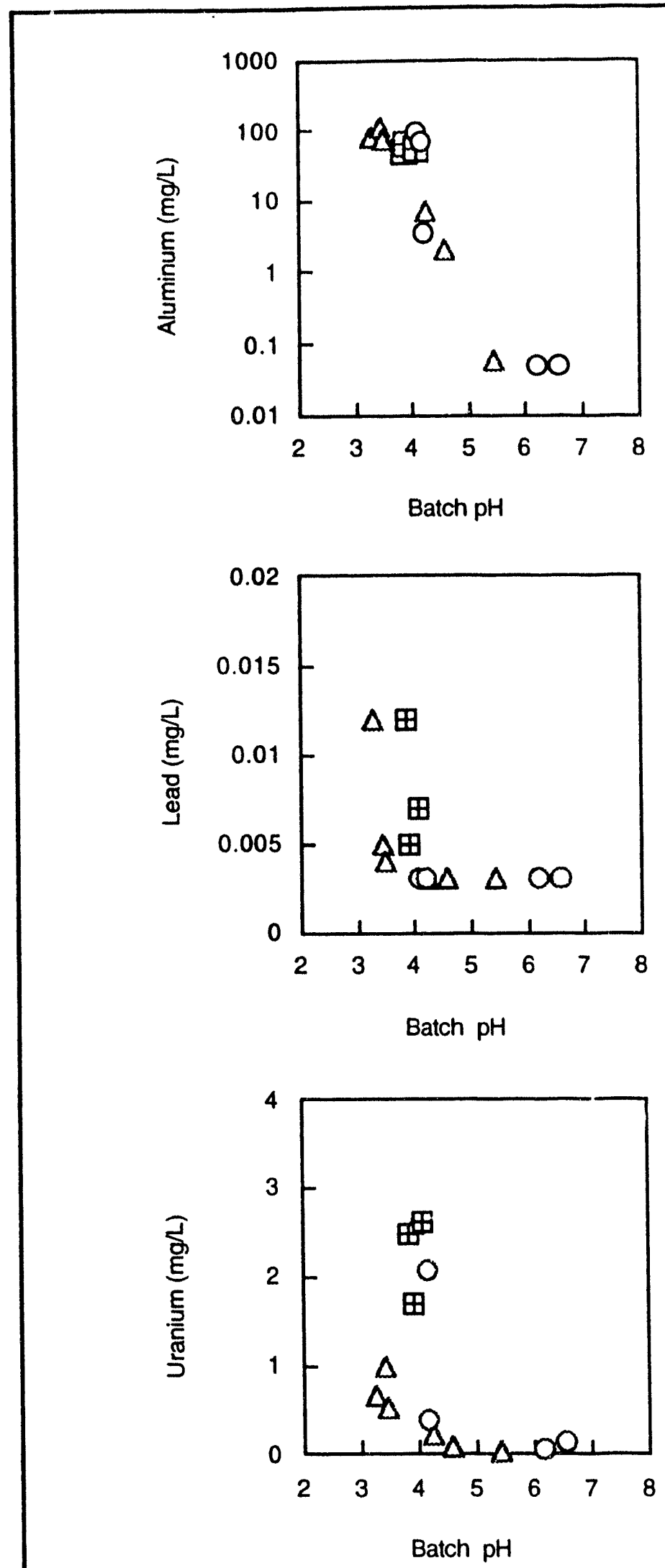
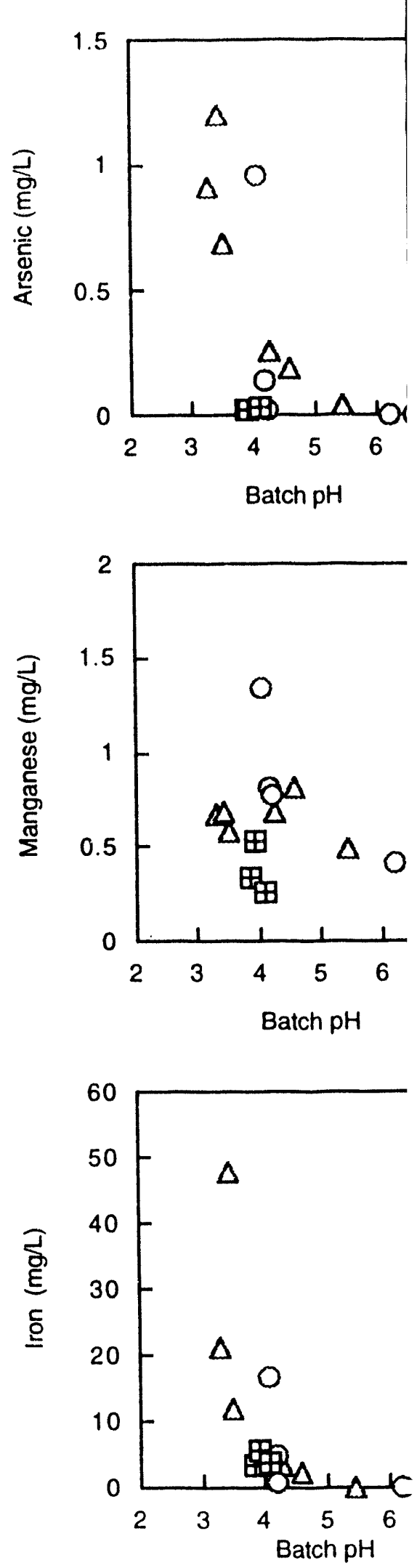

MAC: NON-SITE/SPECIAL STUDIES/SUBPILE/FIGURES.3 

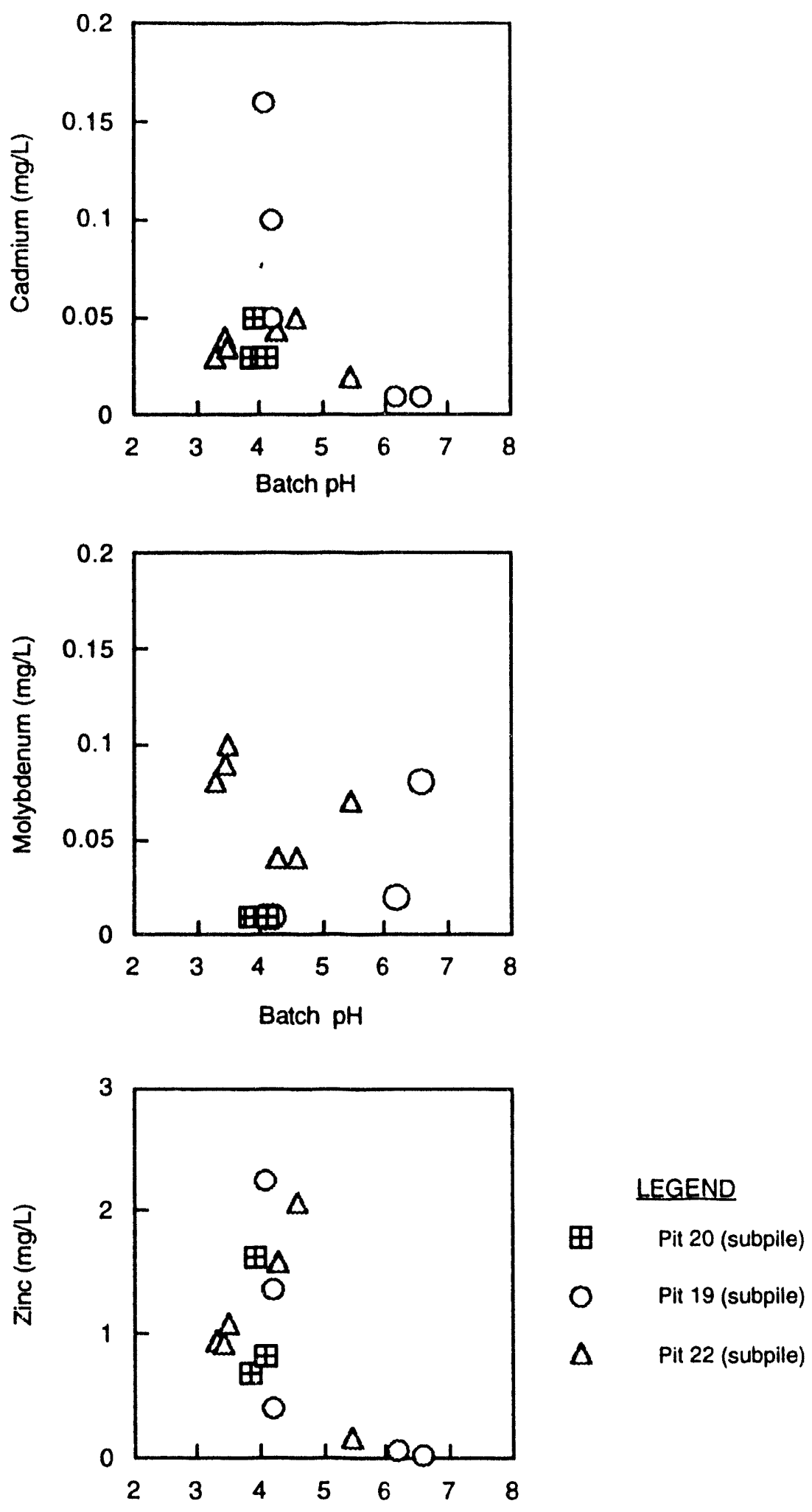

Batch pH

FIGURE 5.3

SUBPILE SEDIMENT BATCH TEST METALS

CONCENTRATIONS VERSUS FINAL $\mathrm{pH}$

OF BATCH TEST SOLUTIONS 
Table 5.5 Acid leach batch te:

\begin{tabular}{|c|c|c|c|c|c|c|c|c|}
\hline \multirow[b]{2}{*}{ Location } & \multirow[b]{2}{*}{ Depth ID } & \multicolumn{2}{|c|}{ Depth } & \multirow[b]{2}{*}{ Sample 1D } & \multirow[b]{2}{*}{ PH } & \multirow{2}{*}{$\begin{array}{c}\text { Ec } \\
\mu s / \mathrm{cm}\end{array}$} & \multirow{2}{*}{$\begin{array}{c}\text { Al } \\
\mathrm{mg} /\end{array}$} & \multirow{2}{*}{$\begin{array}{c}\text { As } \\
\mathrm{mgn}\end{array}$} \\
\hline & & (tt) & $(m)$ & & & & & \\
\hline $\begin{array}{l}21^{\circ} \\
21\end{array}$ & $\begin{array}{l}001 \\
004\end{array}$ & $\begin{array}{l}2.5 \\
6.5\end{array}$ & $\begin{array}{l}0.75 \\
2.0\end{array}$ & $\begin{array}{l}\text { 01P1 } \\
\text { 04P1 }\end{array}$ & $\begin{array}{l}6.47 \\
6.28\end{array}$ & $\begin{array}{l}1460 \\
1530\end{array}$ & $\begin{array}{l}<0.05 \\
<0.05\end{array}$ & $\begin{array}{l}<0 . c \\
<0 . C\end{array}$ \\
\hline $\begin{array}{l}23^{\circ} \\
23\end{array}$ & $\begin{array}{l}002 \\
004\end{array}$ & $\begin{array}{l}2.5 \\
5.5\end{array}$ & $\begin{array}{l}0.75 \\
1.7\end{array}$ & $\begin{array}{l}02 P 1 \\
04 P 1\end{array}$ & $\begin{array}{l}6.59 \\
6.67\end{array}$ & $\begin{array}{l}1530 \\
1570\end{array}$ & $\begin{array}{l}<0.05 \\
<0.05\end{array}$ & $\begin{array}{r}<0 . C \\
0 . C\end{array}$ \\
\hline $\begin{array}{c}20^{b} \\
20\end{array}$ & $\begin{array}{l}002 \\
004\end{array}$ & $\begin{array}{l}0.5 \\
2.5\end{array}$ & $\begin{array}{l}0.15 \\
0.75\end{array}$ & $\begin{array}{l}02 P 1 \\
04 P 1\end{array}$ & $\begin{array}{l}5.88 \\
6.36\end{array}$ & $\begin{array}{l}1540 \\
1770\end{array}$ & $\begin{array}{l}<0.05 \\
<0.05\end{array}$ & $\begin{array}{r}<0 . C \\
0 . C\end{array}$ \\
\hline $\begin{array}{l}19^{b} \\
19\end{array}$ & $\begin{array}{l}002 \\
006\end{array}$ & $\begin{array}{l}1.5 \\
5.5\end{array}$ & $\begin{array}{l}0.5 \\
1.7\end{array}$ & $\begin{array}{l}02 P 1 \\
06 P 1\end{array}$ & $\begin{array}{l}4.30 \\
6.44\end{array}$ & $\begin{array}{l}2470 \\
1450\end{array}$ & $\begin{array}{c}60.0 \\
0.06\end{array}$ & $\begin{array}{r}0.5 \\
<0 . C\end{array}$ \\
\hline $\begin{array}{l}22^{b} \\
22\end{array}$ & $\begin{array}{l}002 \\
006\end{array}$ & $\begin{array}{l}0.5 \\
5.5\end{array}$ & $\begin{array}{l}0.15 \\
1.7\end{array}$ & $\begin{array}{l}\text { 02P1 } \\
\text { 06P1 }\end{array}$ & $\begin{array}{l}3.61 \\
4.13\end{array}$ & $\begin{array}{l}2680 \\
2310\end{array}$ & $\begin{array}{l}71.5 \\
44.7\end{array}$ & $\begin{array}{l}1 . \approx \\
0 . t\end{array}$ \\
\hline
\end{tabular}

Background test pits.

bSubpile test pits.

Key: Al - aluminum, As - arsenic, Cd - cadmium, Fe - iron, Pb - lead, Mn - manganese, Mo - molybdenum, U 
tata of iron-hydroxide-coated pebbles

\begin{tabular}{|c|c|c|c|c|c|c|c|c|}
\hline & $\begin{array}{c}\text { Cd } \\
\text { mgh }\end{array}$ & $\begin{array}{c}F \bullet \\
m g h\end{array}$ & $\begin{array}{c}\mathrm{Pb} \\
\mathrm{mg} / \mathrm{h}\end{array}$ & $\underset{m g n}{M n}$ & $\begin{array}{c}\text { Mo } \\
\mathrm{mg} \Omega\end{array}$ & $\begin{array}{c}V \\
m g h\end{array}$ & $\begin{array}{c}2 n \\
m g / L\end{array}$ & $\underset{m g n}{u}$ \\
\hline b5 & $\begin{array}{l}<0.005 \\
<0.005\end{array}$ & $\begin{array}{l}<0.03 \\
<0.03\end{array}$ & $\begin{array}{l}<0.003 \\
<0.003\end{array}$ & $\begin{array}{l}0.33 \\
0.76\end{array}$ & $\begin{array}{l}<0.01 \\
<0.01\end{array}$ & $\begin{array}{l}<0.01 \\
<0.01\end{array}$ & $\begin{array}{l}0.042 \\
0.141\end{array}$ & $\begin{array}{l}0.001 \\
0.001\end{array}$ \\
\hline p5 & $\begin{array}{l}<0.005 \\
<0.005\end{array}$ & $\begin{array}{r}<0.03 \\
<0.03\end{array}$ & $\begin{array}{l}<0.003 \\
<0.003\end{array}$ & $\begin{array}{l}0.95 \\
1.01\end{array}$ & $\begin{array}{l}<0.01 \\
<0.01\end{array}$ & $\begin{array}{l}<0.01 \\
<0.01\end{array}$ & $\begin{array}{r}0.009 \\
<0.005\end{array}$ & $\begin{array}{l}0.002 \\
0.001\end{array}$ \\
\hline $\begin{array}{l}b_{5} \\
p_{7}\end{array}$ & $\begin{array}{l}<0.02 \\
<0.02\end{array}$ & $\begin{array}{r}0.86 \\
<0.03\end{array}$ & $\begin{array}{l}<0.003 \\
<0.003\end{array}$ & $\begin{array}{l}0.47 \\
0.27\end{array}$ & $\begin{array}{r}<0.01 \\
0.03\end{array}$ & $\begin{array}{l}<0.01 \\
<0.01\end{array}$ & $\begin{array}{l}0.074 \\
0.023\end{array}$ & $\begin{array}{l}0.092 \\
0.193\end{array}$ \\
\hline p5 & $\begin{array}{l}0.043 \\
<0.02\end{array}$ & $\begin{array}{l}10.3 \\
<0.03\end{array}$ & $\begin{array}{l}<0.003 \\
<0.003\end{array}$ & $\begin{array}{l}0.59 \\
0.35\end{array}$ & $\begin{array}{r}<0.01 \\
0.03\end{array}$ & $\begin{array}{l}<0.01 \\
<0.01\end{array}$ & $\begin{array}{l}0.861 \\
0.092\end{array}$ & $\begin{array}{l}1.02 \\
0.058\end{array}$ \\
\hline 6 & $\begin{array}{l}0.027 \\
0.043\end{array}$ & $\begin{array}{c}27.4 \\
4.79\end{array}$ & $\begin{array}{l}<0.003 \\
<0.003\end{array}$ & $\begin{array}{l}0.44 \\
0.27\end{array}$ & $\begin{array}{l}0.08 \\
0.04\end{array}$ & $\begin{array}{l}0.07 \\
0.01\end{array}$ & $\begin{array}{l}0.488 \\
1.01\end{array}$ & $\begin{array}{l}0.588 \\
1.00\end{array}$ \\
\hline
\end{tabular}

uranium, $\mathrm{V}$ - vanadium, $\mathrm{Zn}$ - zinc, Ec - conductivity, $\mu \mathrm{S} / \mathrm{cm}$ - millisiemens por contimeter. 


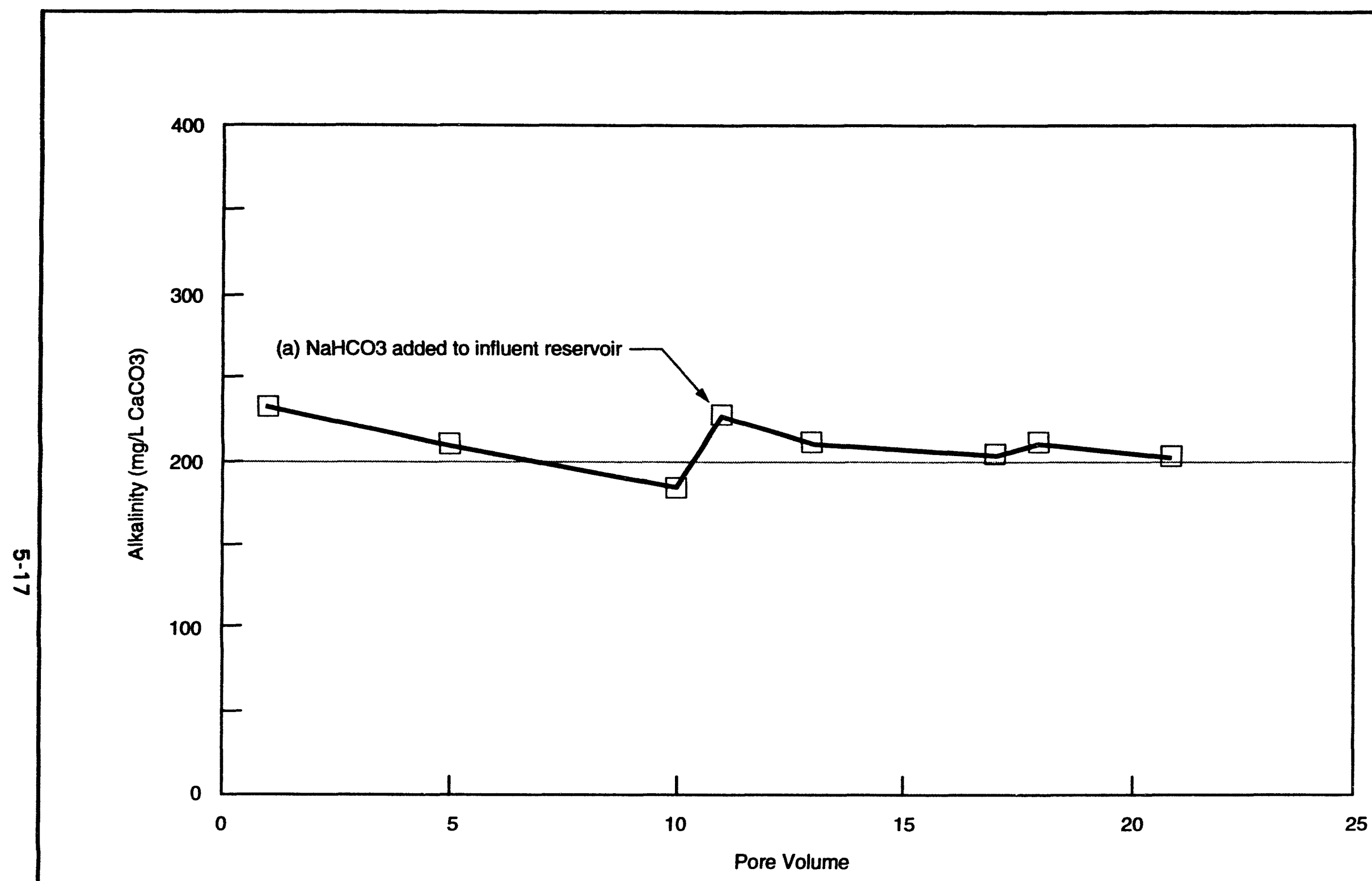

(a) Sodium bicarbonate ( $\mathrm{NaHCO}$ )

added to keep the alkalinity of the

influent solution above $200 \mathrm{mg} / \mathrm{CaCO}$.

\author{
FIGURE 5.4
}

ALKALINITY OF BACKGROUND GROUND WATER INFLUENT SOLUTION

USED IN THE GUNNISON SUBPILE COLUMN EXPERIMENT 


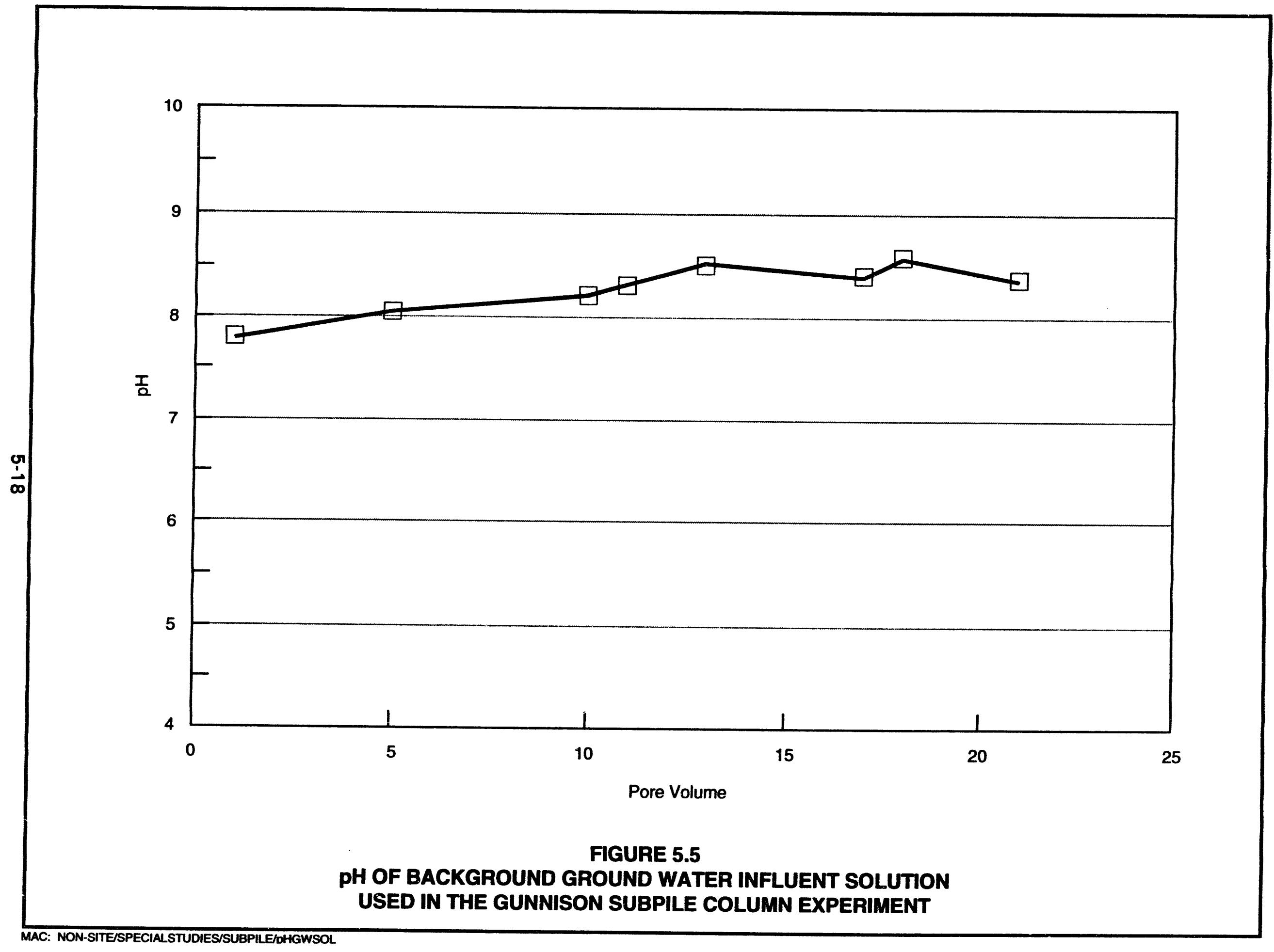


The column test experiment consisted of five columns, each packed with sediment from one test pit. Column 1 was packed with sediment from background test pit 21; column 2 with sediment from background test pit 23; column 3 with sediment from subpile test pit 20; column 4 with sediment from subpile test pit 19; and column 5 with sediment from subpile test pit 22 . The columns were packed with discrete layers or "lifts" of sediment of approximately equal mass. Each layer was composed of sediment taken from a different depth in the test pits (Figure 5.6). With this column configuration, as the influent ground water traveled through the column, it interacted with less acidic sediments sampled from progressively deeper levels in the pits. This allowed us to simulate ground water movement either laterally or vertically from highly contaminated subpile sediment into progressively cleaner parts of the subpile or near-pile environment.

The flow rate through the $1.5-\mathrm{ft}(0.5-\mathrm{m})$ long columins was maintained at one pore volume per 48 hours, which approximates our current best estimate of the average linear horizontal ground water velocity 10.75 foot/day [0.23 meter/dayl) at Gunnison. The empirically determined pore volumes for the five columns ranged between 550 and $625 \mathrm{~mL}$. Temperature, $\mathrm{pH}$, electrical conductivity, and alkalinity were measured from unfiltered samples from each pore volume. Samples were then filtered $(0.45$ micrometer) and preserved, where appropriate, for analysis of selected cations and anions. The number of pore volumes collected from the columns ranged between 15 and 22 . Details of column construction and the experimental procedure are given in Attachment $C$.

During the column experiment, samples were screened periodically for the presence of trace metals using inductively coupled plasma-mass spectrometry (ICP-MS) semiquantitative monitoring techniques. This approach provided realtime data acquisition and allowed us to better monitor the progress of the experiment in each column. Using $\mathrm{pH}$, alkalinity, conductivity, and the ICP-MS semiquantitative trace element data, we were able to determine that during the experiment the chemistry of the ground water passing out of the two background columns ( 1 and 2) was very similar. Consequently, pore volume samples from only one background column (column 2/pit 23) were selected for quantitative major cation and trace element analysis. This approach also indicated that the chemistry of pore volume solutions from columns 3 (subpile pit 20), 4 (subpile pit 19), and 5 (subpile pit 22) were not similar. Several pore volume solutions from each of these 3 columns were also selected for quantitative analysis. The chemical data obtained for each column are summarized in Table 5.6.

\subsection{1 pH, conductivity, and alkalinity}

\section{pH}

Almost all of the column test solutions from columns 1 through 4 maintained a pH above 7.0 (Table 5.6). The background columns (1 and 2) typically produced effluent with $\mathrm{pH}$ levels that ranged from 7.7 to 8.2. A subtle, 


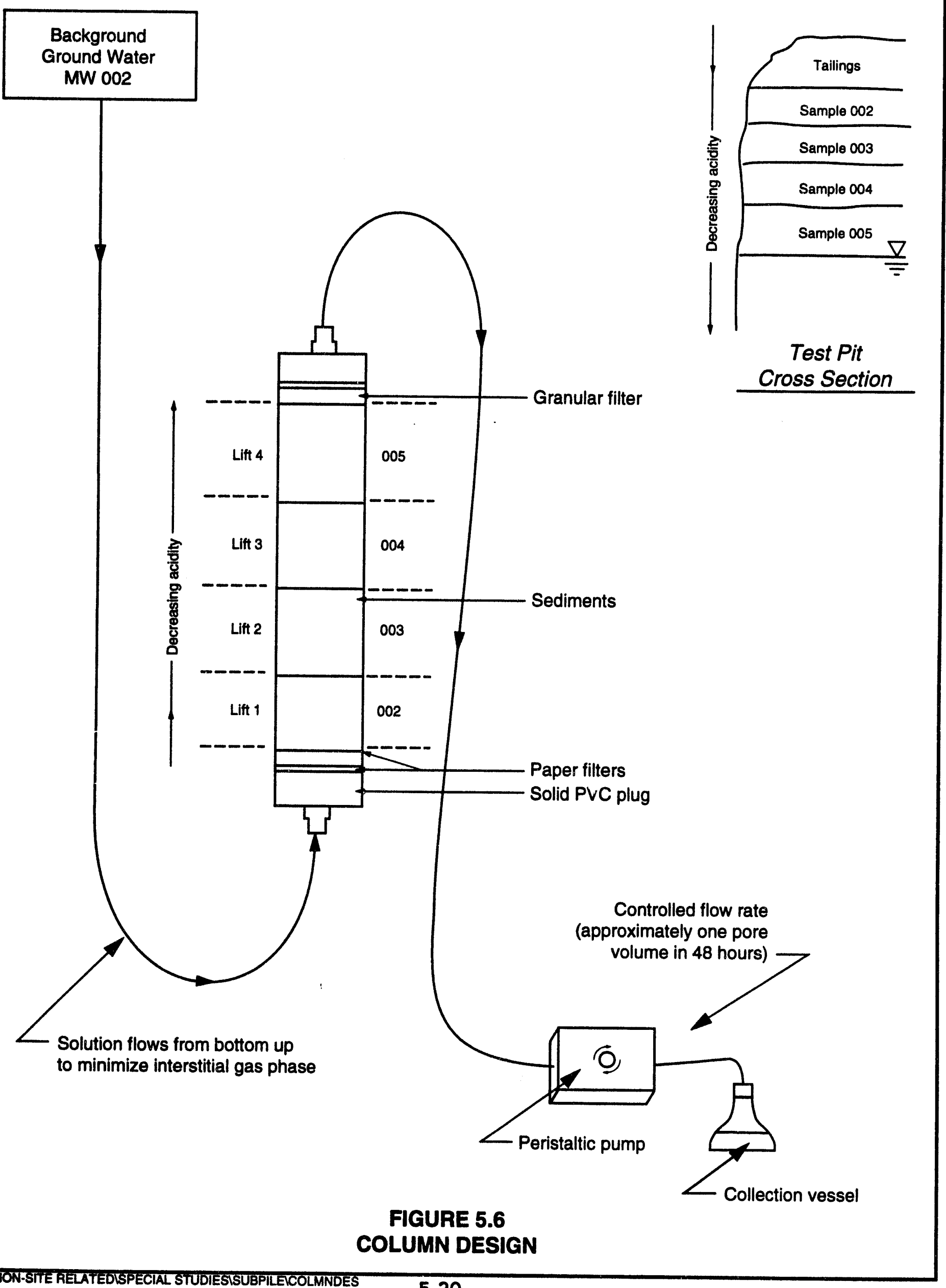


Table 5.6 Gunnison s

Column 1 (Pit 21

\begin{tabular}{|c|c|c|c|c|c|c|c|c|c|c|}
\hline Pore volume & $\mathbf{p H}$ & $\begin{array}{c}\text { Ec } \\
\mathrm{ma} / \mathrm{cm}\end{array}$ & $\begin{array}{c}\text { Alkalinity } \\
\mathrm{mg} / \mathrm{CaCO} \\
\end{array}$ & Al & As & Ca & Cd & Chloride & $\mathrm{Fe}$ & $\mathbf{K}$ \\
\hline 1 & 7.76 & 627 & 262 & & & & & 20.5 & & \\
\hline 2 & 8.12 & 480 & 273 & & & & & 7.5 & & \\
\hline 3 & 7.95 & 460 & 249 & & & & & 6.5 & & \\
\hline 4 & 8.16 & 446 & 238 & & & & & 6.7 & & \\
\hline 5 & 8.23 & 440 & 244 & & & & & 6.7 & & \\
\hline 6 & 8.18 & 457 & 258 & & & & & 6.9 & & \\
\hline 7 & 8.06 & 460 & 230 & & & & & 6.7 & & \\
\hline 8 & 8.09 & 447 & 226 & & & & & & & \\
\hline 9 & 8.17 & 436 & 222 & & & & & & & \\
\hline 10 & 7.99 & 436 & 221 & & & & & 6.4 & & \\
\hline 11 & 7.87 & 435 & 214 & & & & & & & \\
\hline 12 & 7.8 & 437 & 214 & & & & & & & \\
\hline 13 & 7.92 & 432 & 220 & & & & & & & \\
\hline 14 & 7.78 & 453 & 219 & & & & & 7.6 & & \\
\hline 15 & 7.86 & 480 & 221 & & & & & & & \\
\hline \multicolumn{11}{|l|}{16} \\
\hline \multicolumn{11}{|l|}{17} \\
\hline \multicolumn{11}{|l|}{18} \\
\hline \multicolumn{11}{|l|}{19} \\
\hline \multicolumn{11}{|l|}{20} \\
\hline \multicolumn{11}{|l|}{21} \\
\hline \multicolumn{11}{|l|}{22} \\
\hline Detect limit & & & & 0.05 & 0.005 & 0.5 & 0.001 & 0.5 & 0.03 & 0.1 \\
\hline
\end{tabular}

Units of all constituents except $\mathrm{pH}$, conductiviry $(E c)$, and alkalinity are in $\mathrm{mg} / \mathrm{L}$. 
Ibpile column 1-5 test results

background sediments)

\begin{tabular}{|c|c|c|c|c|c|c|c|c|c|c|}
\hline $\mathbf{M g}$ & Mn & Mo & $\mathrm{Na}$ & $\mathbf{P b}$ & $\mathrm{SiO}_{2}$ & $\mathrm{SO}_{4}{ }^{2}$ & TDS & $\mathbf{u}$ & v & $2 n$ \\
\hline & \multirow{5}{*}{$r$} & & & & & 95 & 410 & & & \\
\hline & & & & & & 60 & 300 & & & \\
\hline & & & & & & 45 & 300 & & & \\
\hline & & & & & & 39 & 310 & & & \\
\hline & & & & & & 47 & 310 & & & \\
\hline & & & & & & 64 & 280 & & & \\
\hline & & & & & & 29 & 270 & & & \\
\hline
\end{tabular}

10

16

0.1

0.1

1

10

0.001

$0.01 \quad 0.01-0.05$ 
Table 5.6 Gunnison subp

Column 2 (Pit

\begin{tabular}{|c|c|c|c|c|c|c|c|c|c|}
\hline Pore volume & pH & $\underset{\mathrm{ma} / \mathrm{cm}}{\mathrm{Ec}}$ & 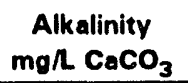 & Al & As & Ca & Cd & Chloride & $\mathbf{F e}$ \\
\hline 1 & 7.93 & 690 & 268 & $<0.05$ & $<0.005$ & 104 & $<0.001$ & 24.2 & $<0.03$ \\
\hline 2 & 8.12 & 496 & 282 & $<0.05$ & $<0.005$ & 76.1 & $<0.001$ & 8.6 & $<0.03$ \\
\hline 3 & 8.18 & 490 & 262 & $<0.05$ & $<0.005$ & & $<0.001$ & 6.7 & $<0.03$ \\
\hline 4 & 8.1 & 474 & 284 & & & & & 6.7 & \\
\hline 5 & 8.19 & 490 & 259 & & & & & 6.9 & \\
\hline 6 & 8.11 & 495 & 267 & & & & & 6.8 & \\
\hline 7 & 8.06 & 465 & 245 & $<0.05$ & $<0.005$ & 50.3 & $<0.001$ & 6.7 & 0.13 \\
\hline 8 & 8.13 & 465 & 240 & & & & & & \\
\hline 9 & 7.95 & 455 & 232 & & & & & & \\
\hline 10 & 7.99 & 451 & 231 & $<0.05$ & $<0.005$ & 42.7 & $<0.001$ & 7.2 & 0.1 \\
\hline 11 & 7.83 & 446 & 223 & & & & & & \\
\hline 12 & 7.82 & 438 & 218 & $<0.05$ & $<0.005$ & & $<0.001$ & & 0.12 \\
\hline 13 & 7.97 & 433 & 219 & & & & & & \\
\hline 14 & 7.95 & 444 & 223 & $<0.05$ & $<0.005$ & & $<0.001$ & 7.3 & 0.11 \\
\hline 15 & 8.06 & 440 & 221 & $<0.05$ & $<0.005$ & 36.5 & $<0.001$ & & 0.16 \\
\hline 16 & 7.98 & 445 & 226 & & & & & & \\
\hline \multicolumn{10}{|l|}{17} \\
\hline \multicolumn{10}{|l|}{18} \\
\hline \multicolumn{10}{|l|}{19} \\
\hline \multicolumn{10}{|l|}{20} \\
\hline \multicolumn{10}{|l|}{21} \\
\hline \multicolumn{10}{|l|}{22} \\
\hline Detect limit & & & & 0.05 & 0.005 & 0.5 & 0.001 & 0.5 & 0.03 \\
\hline
\end{tabular}

Units of all constituents except $\mathrm{pH}$, conductivity (Ec), and alkalinity are in $\mathrm{mg} / \mathrm{L}$. 
ie column 1-5 test results (continued)

\section{:3 background sediments)}

\begin{tabular}{|c|c|c|c|c|c|c|c|c|c|c|c|}
\hline & $\mathbf{M g}$ & Mn & Mo & Na & $\mathbf{P b}$ & $\mathrm{SiO}_{2}$ & $\mathrm{SO}_{4}{ }^{2-}$ & TDS & $\mathbf{U}$ & $\mathbf{v}$ & $\mathrm{Zn}$ \\
\hline 3.6 & 19.4 & 0.02 & $<0.01$ & 29.7 & $<0.003$ & 20.1 & 111 & 460 & 0.015 & $<0.01$ & 0.02 \\
\hline \multirow[t]{5}{*}{3} & 14.6 & 0.37 & 0.02 & 37.7 & $<0.003$ & 19.7 & 56 & 360 & 0.012 & $<0.01$ & 0.02 \\
\hline & & 0.54 & 0.01 & & $<0.003$ & & 45 & 310 & 0.011 & $<0.01$ & 0.02 \\
\hline & & & & & & & 45 & 310 & & & \\
\hline & & & & & & & 45 & 300 & & & \\
\hline & $\cdot$ & & & & & & 45 & 300 & & & \\
\hline 3.3 & 9.3 & 0.66 & $<0.01$ & 55.8 & $<0.003$ & 22 & 39 & 310 & 0.004 & $<0.01$ & $<0.01$ \\
\hline \multirow[t]{3}{*}{3.4} & 7.8 & 0.55 & $<0.01$ & 56.5 & $<0.003$ & 22.6 & 29 & & 0.002 & $<0.01$ & 0.01 \\
\hline & & 0.51 & $<0.01$ & & $<0.003$ & & & & $<0.001$ & $<0.01$ & $<0.01$ \\
\hline & & 0.54 & $<0.01$ & & $<0.003$ & & 16 & & $<0.001$ & $<0.01$ & $<0.01$ \\
\hline 3.2 & 6.6 & 0.49 & $<0.01$ & 63.2 & $<0.003$ & 22 & & & $<0.001$ & $<0.01$ & $<0.01$ \\
\hline
\end{tabular}

0.1

0.1

$0.01 \quad 0.001-0.01$

0.01

0.003

0.1

1

10

0.001

$0.01 \quad 0.01-0.05$ 
Table 5.6 Gunnison sut

Column 3

\begin{tabular}{|c|c|c|c|c|c|c|c|c|c|}
\hline Pore volume & $\mathrm{pH}$ & $\begin{array}{c}\text { Ec } \\
\mu s / c m\end{array}$ & $\begin{array}{c}\text { Alkalinity } \\
\mathrm{mg} \Omega \mathrm{CaCO}_{3} \\
\end{array}$ & Al & As & Ca & Cd & Chloride & Fo \\
\hline 1 & 7.12 & 2200 & 24 & $<0.05$ & 0.005 & 480 & 0.025 & 17.3 & $<0.03$ \\
\hline 2 & 7.16 & 1550 & 30 & 0.06 & $<0.005$ & 332 & 0.022 & 8.6 & $<0.03$ \\
\hline 3 & 7.04 & 1260 & 32 & $<0.05$ & $<0.005$ & 236 & 0.013 & 7.1 & $<0.03$ \\
\hline 4 & 6.98 & 918 & 50 & $<0.05$ & $<0.005$ & 168 & 0.009 & 6.8 & $<0.03$ \\
\hline 5 & 7.05 & 825 & 54 & & & & & 6.8 & \\
\hline 6 & 7.07 & 685 & 49 & & & & & 6.7 & \\
\hline 7 & 7.75 & 605 & 120 & $<0.05$ & $<0.005$ & 71.4 & 0.004 & 6.7 & $<0.03$ \\
\hline 8 & 7.05 & 551 & 56 & & & & & & \\
\hline 9 & 7.39 & 487 & 62 & & & & & 6.8 & \\
\hline 10 & 7.33 & 462 & 68 & $<0.05$ & $<0.005$ & 37.3 & 0.002 & 6.8 & $<0.03$ \\
\hline 11 & 7.13 & 428 & 74 & & & & & & \\
\hline 12 & 7.1 & 416 & 80 & $<0.05$ & $<0.005$ & & 0.001 & 6.9 & $<0.03$ \\
\hline 13 & 7.13 & 394 & 77 & & & & & & \\
\hline 14 & 7.48 & 395 & 94 & $<0.05$ & $<0.005$ & 23.1 & $<0.001$ & 7 & $<0.03$ \\
\hline 15 & 7.5 & 400 & 104 & & & & & & \\
\hline 16 & 7.65 & 396 & 110 & $<0.05$ & $<0.005$ & 19.8 & $<0.001$ & 6.2 & $<0.03$ \\
\hline 17 & 7.35 & 396 & 111 & & & & & & \\
\hline 18 & 7.17 & 394 & 117 & $<0.05$ & $<0.005$ & & $<0.001$ & & $<0.03$ \\
\hline 19 & 7.01 & 393 & 114 & & & & & & \\
\hline 20 & 7.19 & 385 & 118 & $<0.05$ & $<0.005$ & & $<0.001$ & & $<0.03$ \\
\hline \multicolumn{10}{|l|}{21} \\
\hline \multicolumn{10}{|l|}{22} \\
\hline Detect limit & & & & 0.05 & 0.005 & 0.5 & 0.001 & 0.5 & 0.03 \\
\hline
\end{tabular}

Units of all constituents except $\mathrm{pH}$, conductivity (Ec), and alkalinity are in $\mathrm{mg} / \mathrm{L}$. 
pile column 1-5 test results (continued)

[Pit 20 subpile sediments)

\begin{tabular}{|c|c|c|c|c|c|c|c|c|c|c|c|}
\hline$K$ & $\mathbf{M g}$ & $M n$ & Mo & Na & $\mathrm{Pb}$ & $\mathrm{SiO}_{2}$ & $\mathrm{SO}_{4}^{2}$ & TDS & $\mathbf{u}$ & $v$ & $\mathrm{Zn}$ \\
\hline 8.3 & 47.8 & 1.89 & $<0.01$ & 55.5 & $<0.003$ & 19.1 & 1520 & 2220 & 0.042 & $<0.01$ & 0.21 \\
\hline 6.5 & 32.2 & 1.26 & $<0.01$ & 49.4 & $<0.003$ & 16.9 & 1080 & 1570 & 0.092 & $<0.01$ & 0.17 \\
\hline 5.6 & 22.2 & 0.85 & $<0.01$ & 48.7 & $<0.003$ & 15.5 & 774 & 1120 & 0.091 & $<0.01$ & 0.12 \\
\hline \multirow[t]{3}{*}{4.9} & 17.1 & 0.56 & $<0.01$ & 49.4 & $<0.003$ & 14.2 & 560 & 840 & 0.076 & $<0.01$ & 0.07 \\
\hline & & & & & & & 438 & 660 & & & \\
\hline & & & & & & & 354 & 510 & & & \\
\hline \multirow[t]{2}{*}{3.5} & 9.7 & 0.21 & $<0.01$ & 51.9 & $<0.003$ & 11 & 290 & 410 & 0.041 & $<0.01$ & 0.03 \\
\hline & & & & & & & 171 & & & & \\
\hline \multirow[t]{2}{*}{2.6} & 6.5 & 0.1 & 0.01 & 54.2 & $<0.003$ & 8.4 & 156 & & 0.023 & $<0.01$ & 0.01 \\
\hline & & 0.08 & 0.01 & & $<0.003$ & & 119 & & 0.016 & $<0.01$ & 0.01 \\
\hline 2.3 & 4.7 & 0.05 & 0.01 & 63.4 & $<0.003$ & 6.8 & 99 & & 0.012 & $<0.01$ & $<0.01$ \\
\hline \multirow[t]{3}{*}{2.1} & 4.4 & 0.04 & 0.01 & 70.5 & $<0.003$ & 6.5 & 114 & & 0.01 & $<0.01$ & $<0.01$ \\
\hline & & 0.04 & 0.01 & & $<0.003$ & & & & 0.008 & $<0.01$ & $<0.01$ \\
\hline & & 0.04 & 0.02 & & $<0.003$ & & & & 0.007 & $<0.01$ & $<0.01$ \\
\hline 0.1 & 0.1 & 0.01 & $0.001-0.01$ & 0.01 & 0.003 & 0.1 & 1 & 10 & 0.001 & 0.01 & $0.01-0.05$ \\
\hline
\end{tabular}


Table 5.6 Gunnison sul

Column 4

\begin{tabular}{|c|c|c|c|c|c|c|c|c|c|}
\hline $\begin{array}{c}\text { Pore } \\
\text { volume }\end{array}$ & $\mathrm{pH}$ & $\begin{array}{c}\text { Ec } \\
\mathrm{me} / \mathrm{cm}\end{array}$ & $\begin{array}{c}\text { Alkalinity } \\
\mathrm{mg} \Omega \mathrm{CaCO}_{3}\end{array}$ & Al & As & Ca & Cd & Chloride & $F_{0}$ \\
\hline 1 & 7.75 & 2690 & 48 & $<0.05$ & $<0.005$ & 622 & $<0.001$ & 15.6 & $<0.03$ \\
\hline 2 & 7.58 & 2490 & 58 & $<0.05$ & $<0.005$ & 575 & $<0.001$ & 10.2 & $<0.03$ \\
\hline 3 & 7.96 & 2440 & 129 & $<0.05$ & $<0.005$ & 592 & $<0.001$ & 7.6 & $<0.03$ \\
\hline 4 & 8.02 & 2390 & 158 & $<0.05$ & $<0.005$ & & $<0.001$ & 7 & $<0.03$ \\
\hline 5 & 7.93 & 2410 & 146 & $<0.05$ & $<0.005$ & 646 & $<0.001$ & 6.7 & $<0.03$ \\
\hline 6 & 7.94 & 2350 & 167 & & & & & 6.7 & \\
\hline 7 & 7.71 & 2480 & 171 & $<0.05$ & $<0.005$ & 629 & $<0.001$ & 6.7 & $<0.03$ \\
\hline 8 & 7.83 & 2490 & 171 & & & & & & \\
\hline 9 & 7.86 & 2500 & 171 & 0.05 & $<0.005$ & & 0.004 & 6.8 & $<0.03$ \\
\hline 10 & 7.73 & 2520 & 167 & $<0.05$ & $<0.005$ & 593 & 0.001 & 6.8 & $<0.03$ \\
\hline 11 & 7.88 & 2500 & 172 & & & & & & \\
\hline 12 & 7.75 & 2490 & 165 & $<0.05$ & $<0.005$ & 632 & 0.009 & 6.8 & $<0.03$ \\
\hline 13 & 7.83 & 2450 & 167 & & & & & & \\
\hline 14 & 7.86 & 2340 & 167 & $<0.05$ & $<0.005$ & & 0.01 & 7.1 & 0.03 \\
\hline 15 & 7.83 & 2150 & 167 & $<0.05$ & $<0.005$ & 546 & 0.01 & & $<0.03$ \\
\hline 16 & 7.78 & 2090 & 174 & $<0.05$ & $<0.005$ & 499 & 0.009 & 6.5 & $<0.03$ \\
\hline 17 & 7.77 & 1923 & 172 & & & & & & \\
\hline 18 & 7.76 & 1853 & 175 & $<0.05$ & $<0.005$ & 407 & 0.007 & 6.5 & $<0.03$ \\
\hline 19 & 7.73 & 1757 & 172 & & & & & & \\
\hline 20 & 7.82 & 1445 & 168 & $<0.05$ & $<0.005$ & 372 & 0.005 & & $<0.03$ \\
\hline \multicolumn{10}{|l|}{21} \\
\hline \multicolumn{10}{|l|}{22} \\
\hline Detect limit & & & & 0.05 & 0.005 & 0.5 & 0.001 & 0.5 & 0.03 \\
\hline
\end{tabular}

Units of all constituents except $\mathrm{pH}$, conductivity (Ec), and alkalinity are in $\mathrm{mg} / \mathrm{L}$. 
ppile column 1-5 test results (continued)

(Pit 19 subpile sediments)

\begin{tabular}{|c|c|c|c|c|c|c|c|c|c|c|c|c|}
\hline $\mathbf{k}$ & Mg & & Mn & Mo & Na & $\mathrm{Pb}$ & $\mathrm{SiO}_{2}$ & $\mathrm{so}_{4}^{2}$ & TDS & $\mathbf{u}$ & $v$ & $2 n$ \\
\hline 11.2 & 52.8 & & 0.32 & 0.27 & 73.9 & $<0.003$ & 4.2 & 2130 & 2900 & 0.311 & $<0.01$ & 0.02 \\
\hline 13 & 51 & & 0.35 & 0.25 & 66.6 & $<0.003$ & 3.6 & 1940 & 2700 & 0.428 & $<0.01$ & $<0.01$ \\
\hline \multirow[t]{2}{*}{14.7} & 42.1 & $r$ & 0.87 & 0.21 & 60.5 & $<0.003$ & 4.2 & 1690 & 2560 & 0.588 & $<0.01$ & 0.07 \\
\hline & & & 1.16 & 0.2 & & $<0.003$ & & 1810 & 2530 & 0.628 & $<0.01$ & $<0.01$ \\
\hline \multirow[t]{2}{*}{14.1} & 32.2 & & 1.11 & 0.17 & 62.6 & $<0.003$ & 5.7 & 1690 & 2600 & 0.616 & $<0.01$ & $<0.01$ \\
\hline & - & & & & & & & 1720 & 2540 & & & \\
\hline \multirow[t]{2}{*}{11} & 24.9 & & 0.97 & 0.13 & 59.3 & $<0.003$ & 6.8 & 1680 & 2560 & 0.568 & $<0.01$ & 0.02 \\
\hline & & & 0.87 & 0.12 & & $<0.003$ & & 1580 & & 0.52 & $<0.01$ & 0.03 \\
\hline 7.6 & 20.4 & & 0.72 & 0.1 & 56.8 & $<0.003$ & 7.2 & 1590 & & 0.5 & $<0.01$ & 0.03 \\
\hline \multirow[t]{2}{*}{6.8} & 19.5 & & 0.64 & 0.09 & 61.2 & $<0.003$ & 8 & 1580 & & 0.472 & $<0.01$ & 0.05 \\
\hline & & & 0.47 & 0.07 & & $<0.003$ & & 1450 & & 0.395 & $<0.01$ & 0.06 \\
\hline 5.3 & 16.5 & & 0.48 & 0.08 & 74.7 & $<0.003$ & 8.2 & & & 0.347 & $<0.01$ & 0.06 \\
\hline 4.9 & 16.1 & & 0.42 & 0.07 & 75.2 & $<0.003$ & 7.9 & 1420 & & 0.316 & $<0.01$ & 0.06 \\
\hline 4 & 13.7 & & 0.32 & 0.06 & 69.5 & $<0.003$ & 7.1 & 1180 & & 0.244 & $<0.01$ & 0.05 \\
\hline 3.6 & 13.5 & & 0.27 & 0.05 & 67.9 & $<0.003$ & 6.4 & & & 0.192 & $<0.01$ & 0.04 \\
\hline 0.1 & 0.1 & & 0.01 & $0.001-0.01$ & 0.01 & 0.003 & 0.1 & 1 & 10 & 0.001 & 0.01 & $0.01-0.05$ \\
\hline
\end{tabular}


Table 5.6 Gunnison s

Column

\begin{tabular}{|c|c|c|c|c|c|c|c|c|c|}
\hline $\begin{array}{l}\text { Pore } \\
\text { volume }\end{array}$ & pH & $\begin{array}{c}\text { Ec } \\
\mathrm{mat} / \mathrm{cm}\end{array}$ & $\begin{array}{c}\text { Alkalinity } \\
\text { mgn } \mathrm{CaCO}_{3}\end{array}$ & Al & As & Ca & Cd & Chloride & $F_{0}$ \\
\hline 1 & 7.3 & 2540 & 46 & $<0.05$ & $<0.005$ & 587 & 0.004 & 17.6 & 0.26 \\
\hline 2 & 6.83 & 2380 & 78 & $<0.05$ & $<0.005$ & & 0.017 & 9.6 & 4.12 \\
\hline 3 & 6.92 & 2430 & 73 & 0.06 & $<0.005$ & 586 & 0.032 & 9.7 & 2.21 \\
\hline 4 & 6.82 & 2450 & 84 & $<0.05$ & $<0.005$ & 569 & 0.032 & 8.7 & 1.01 \\
\hline 5 & 6.57 & 2390 & 75 & 0.15 & $<0.005$ & 558 & 0.032 & 6.7 & 1.27 \\
\hline 6 & 6.67 & 2310 & 73 & & & & & 6.7 & \\
\hline 7 & 6.75 & 2400 & 74 & $<0.05$ & $<0.005$ & 539 & 0.028 & 6.7 & 0.34 \\
\hline 8 & 6.8 & 2390 & 71 & & & & & & \\
\hline 9 & 7.04 & 2400 & 70 & 0.05 & $<0.005$ & & 0.025 & 6.3 & 0.06 \\
\hline 10 & 7.18 & 2420 & 68 & $<0.05$ & $<0.005$ & 571 & 0.027 & 7.1 & 0.03 \\
\hline 11 & 7.15 & 2410 & 70 & & & & & & \\
\hline 12 & 7.23 & 2390 & 68 & $<0.05$ & $<0.005$ & 562 & 0.024 & 7 & $<0.03$ \\
\hline 13 & 7.11 & 2410 & 66 & & & & & & \\
\hline 14 & 7.52 & 2420 & 66 & $<0.05$ & $<0.005$ & & 0.027 & 7.2 & $<0.03$ \\
\hline 15 & 7.24 & 2360 & 66 & $<0.05$ & $<0.005$ & 517 & 0.026 & & $<0.03$ \\
\hline 16 & 7.25 & 2420 & 64 & $<0.05$ & $<0.005$ & 544 & 0.025 & & $<0.03$ \\
\hline 17 & 7.28 & 2420 & 69 & & & & & & \\
\hline 18 & 7.02 & 2420 & 71 & $<0.05$ & $<0.005$ & 580 & 0.024 & 6.7 & 0.07 \\
\hline 19 & 7.15 & 2420 & 65 & & & & & & \\
\hline 20 & 7.18 & 2410 & 67 & $<0.05$ & $<0.005$ & 573 & 0.02 & 6.6 & 0.04 \\
\hline 21 & 7.14 & 2420 & 64 & & & & & & \\
\hline 22 & 6.88 & 2210 & 69 & $<0.05$ & $<0.005$ & & 0.014 & & 0.04 \\
\hline Detect limit & & & & 0.05 & 0.005 & 0.5 & 0.001 & 0.5 & 0.03 \\
\hline
\end{tabular}

Units of all constituents except $\mathrm{pH}$, conductivity $(E c)$, and alkalinity are in $\mathrm{mg} / \mathrm{L}$.

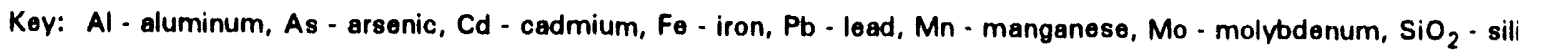




\section{ubpile column 1-5 test results (concluded)}

\section{5 (Pit 22 subpile sediments)}

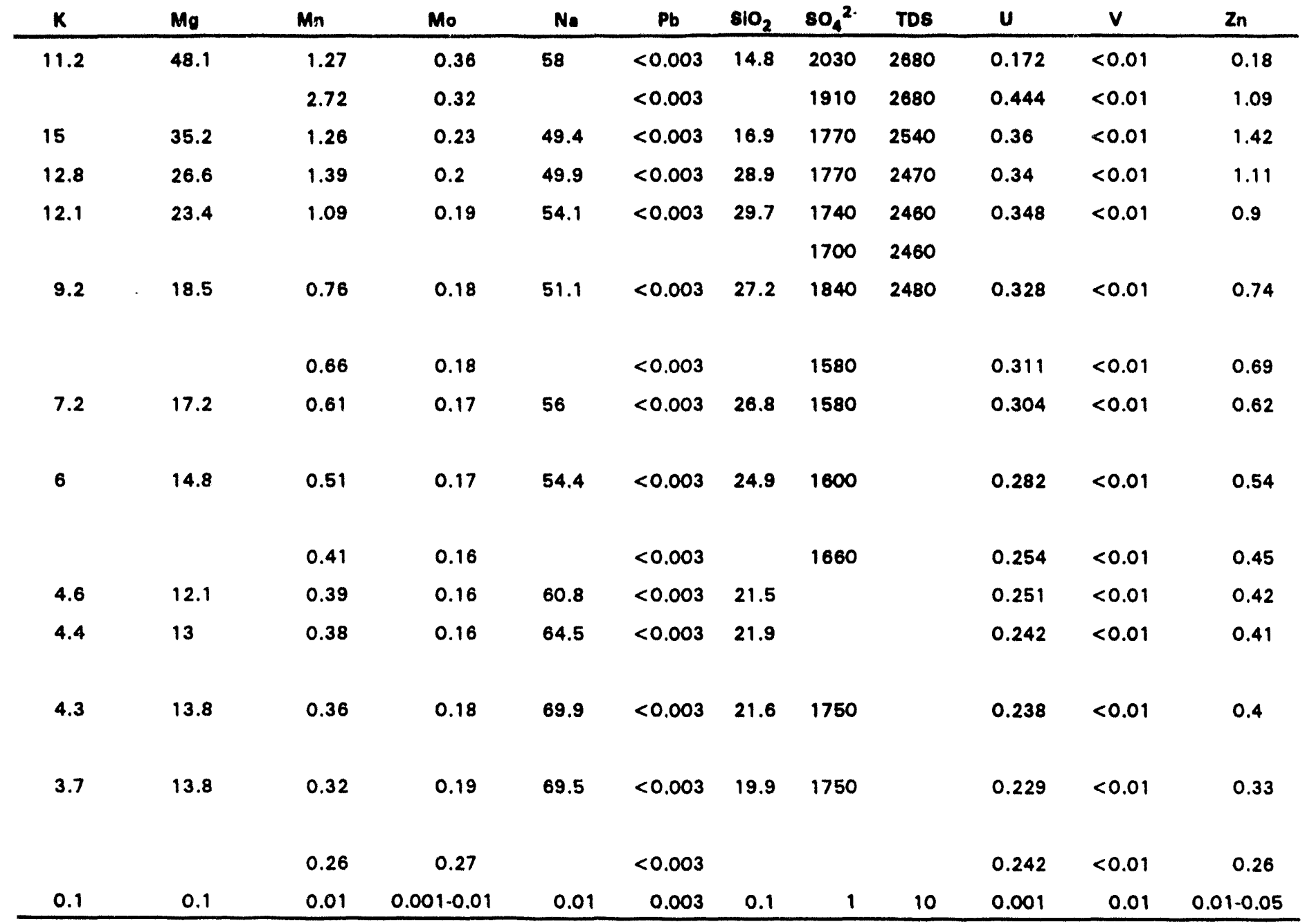

a, $\mathrm{SO}_{4}{ }^{2-}-$ sulfate, $U$ - uranium, $V$ - vanadium, $\mathrm{Zn}-\mathrm{zinc}, \mathrm{Ec}$ - conductivity, $\mu \mathrm{s} / \mathrm{cm}$ - millisiemens per centimeter, TDS - total dissolved solids. 
generally downward trend in the $\mathrm{pH}$ values was observed for the effluent of these columns as the experiment progressed.

Although there were some outliers, the pH of the column 3 (pit 20) solutions generally ranged between 7.0 and 7.3. No clear increasing or decreasing trend in the $\mathrm{pH}$ values was apparent over the 20 pore volumes tested for cot $\mathrm{dmn} 3$ (Figure 5.7).

The $\mathrm{pH}$ of column 4 pore volume solutions generally increased over the first five pore volumes and generally decreased slightly thereafter. Nearly all of the pore volumes eluted from column 4 had a pH between 7.7 and 8.0 (Figure 5.7).

Unlike the solutions from these first four columns, the $\mathrm{pH}$ of the first five pore volumes from column 5 (pit 22) generally trended downward, from a pH of 7.3 in pore volume 1 to 6.57 in pore volume 5 . An upward trend in the $\mathrm{pH}$ then began and continued until pore volume 9, where the pH stabilized at about 7.2. The effluent solutions from column 5 commonly had lower pHs than the equivalent pore volumes from the other columns (Figure 5.7).

\section{Conductivity}

The conductivities of the pore volumes eluted from the background columns generally ranged between 400 and 500 microsiemens/centimeter $(\mu \mathrm{S} / \mathrm{cm})$. The first pore volume eluted from column 3 (pit 20) had a conductivity $(2200 \mu \mathrm{S} / \mathrm{cm})$ significantly higher than that of the background columns (Figure 5.8). The conductivities of the successive pore volumes through this column rapidly dropped to background levels. The conductivities of the column test solutions for columns 4 (pit 19) and 5 (pit 22) were significantly higher than those from the background columns ( 1 and 2 ) throughout the experiment (Figure 5.8). Although the conductivity of samples from column 5 remained relatively constant, the conductivities of column 4 solutions began to drop noticeably at about pore volume 15 .

The elevated conductivities in subpile columns 3, 4, and 5 were probably produced by the steady, equilibrium-controlled dissolution of gypsum from the subpile sediment. Geochemical modeling of selected pore volume solutions from columns 2.5 support this interpretation (Figure 5.9). These data substantiate earlier observations that gypsum is abundant in the sediment from test pits 19 and 22, and far less abundant in sediment from test pits 20, 21, and 23 (see Table 4.3).

\section{Alkalinity}

Due to the slow degassing of $\mathrm{CO}_{2}$, the alkalinity of the influent background ground water drifted downward over time. In order to maintain the alkalinity of the influent water at or near $200 \mathrm{mg} / \mathrm{L} \mathrm{CaCO}_{3}$ (see Figure 5.4), a small amount of sodium bicarbonate $\left(\mathrm{NaHCO}_{3}\right)$ was added to the influent prior to pore volume 11 . 


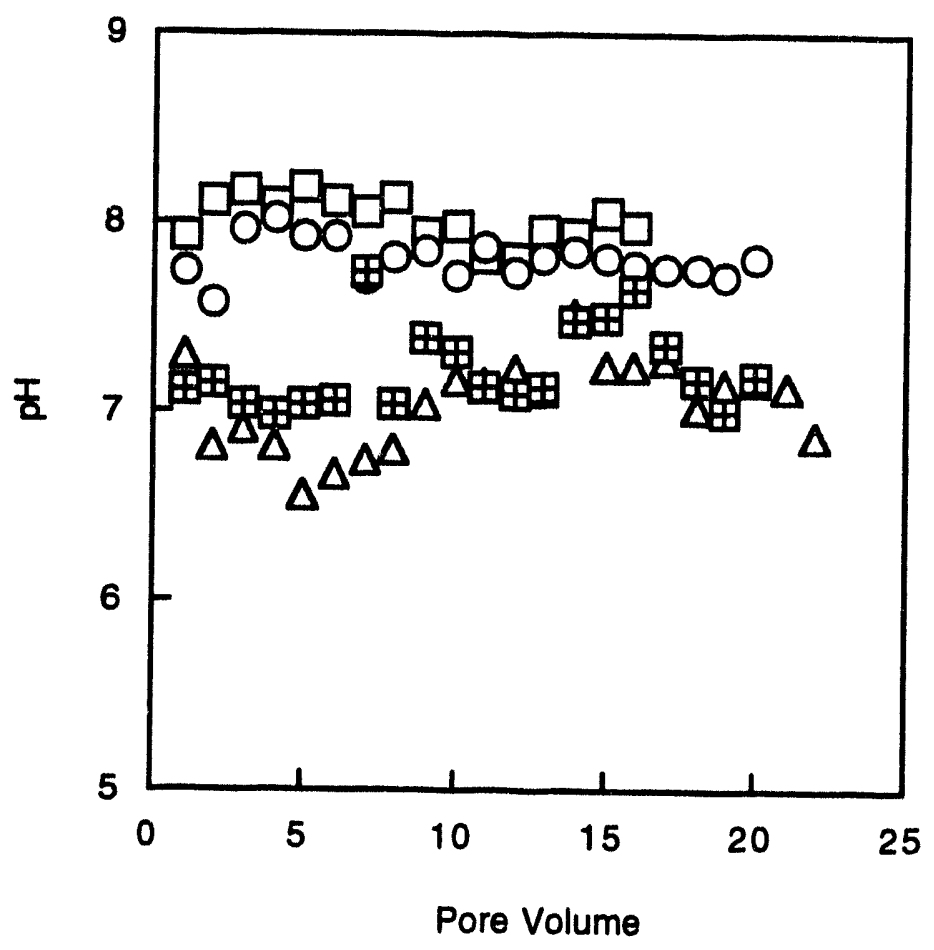

LEGEND

$\begin{array}{ll}\square & \text { (a) Column } 2 \text { (Pit 23) } \\ \text { 田 } & \text { (b) Column } 3 \text { (Pit 20) } \\ \text { O } & \text { (b) Column } 4 \text { (Pit 19) } \\ \Delta & \text { (b) Column } 5 \text { (Pit 22) }\end{array}$

(a) Background sediments

(b) Subplle sediments

FIGURE 5.7

PH VERSUS PORE VOLUME 


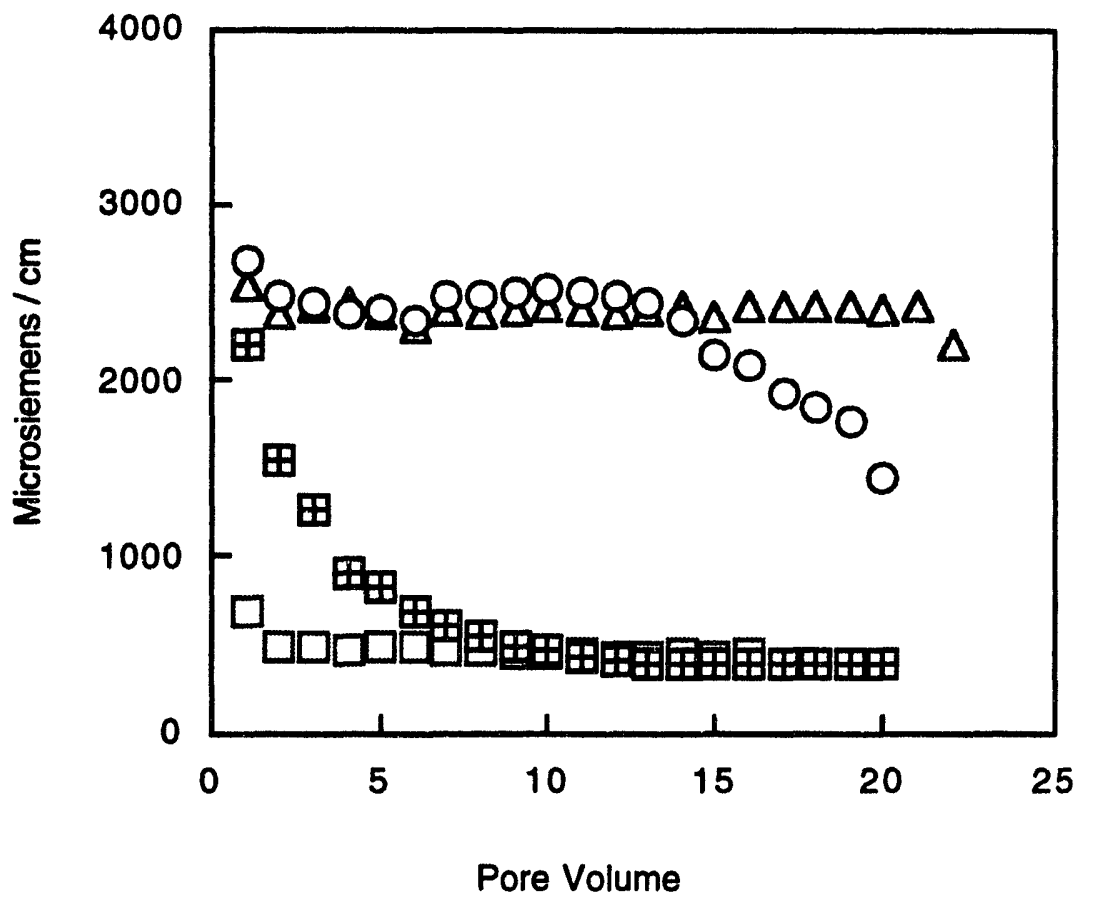

LEGEND
$\square \quad$ (a) Column 2 (Pit 23)
田 (b) Column 3 (Pit 20)
O (b) Column 4 (Pit 19)
$\Delta \quad$ (b) Column 5 (Pit 22)

(a) Background sediments

(b) Subpile sediments

FIGURE 5.8

CONDUCTIVITY VERSUS PORE VOLUME 


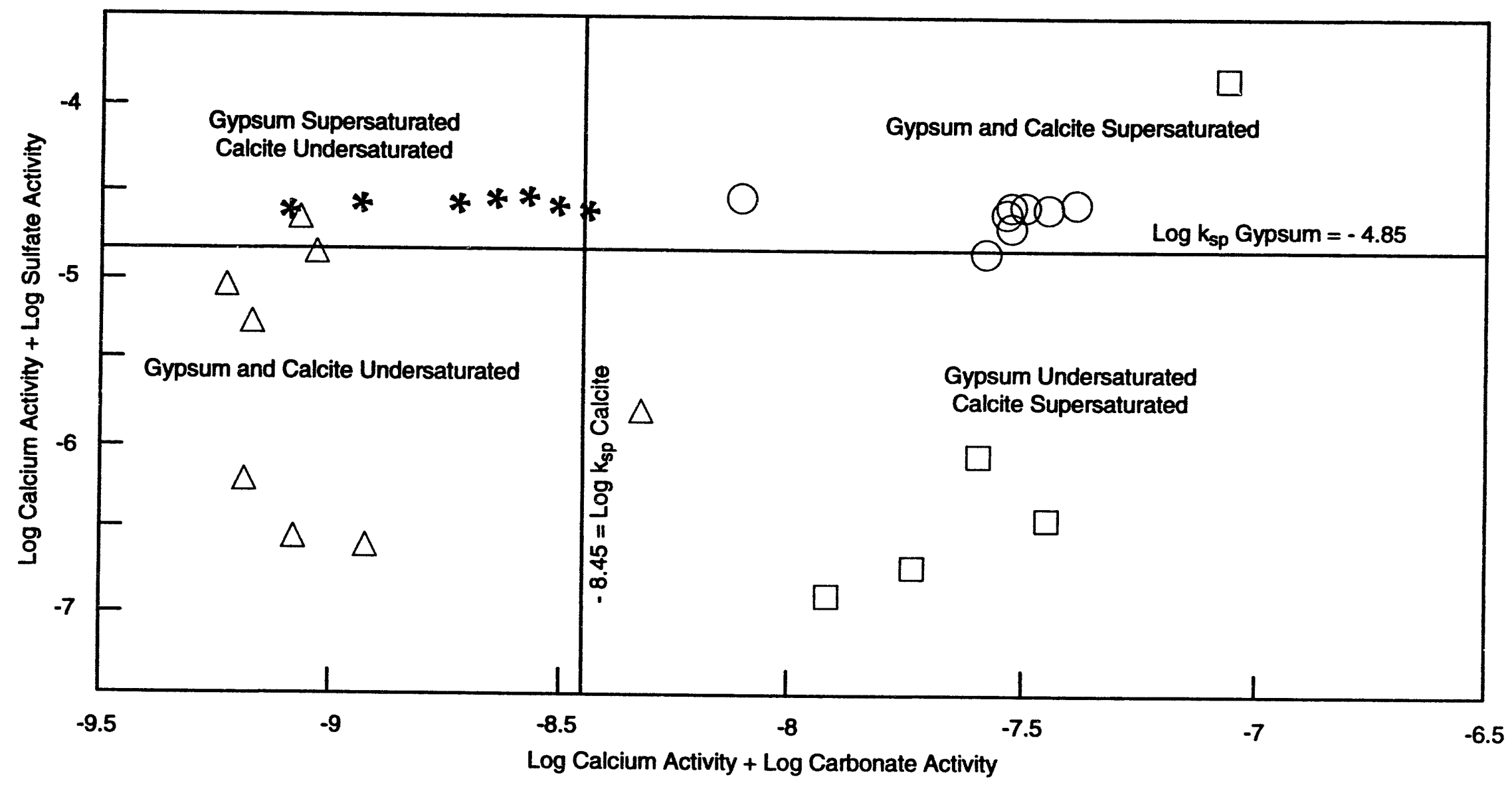

Note: The plotted symbols denote the Gypsum and Calcite ion activity products (IAP) for specific pore volume solutions. The IAP were calculated using the geochemical code PHREEQE

(Parkhurst et al. 1980). If the IAP for Gypsum or Calcite in these

solutions exceeds the solubility product $\left(k_{\mathrm{sp}}\right)$ for these minerals,

then the pore volume solutions are supersaturated with these minerals.

\section{LEGEND}

$\square \quad$ Column 2 (Pit 23, Background)

$\triangle$ Column 3 (Pit 20, Subpile)

$\bigcirc$ Column 4 (Pit 19, Subpile)

* Column 5 (Pit 22, Subpile)

FIGURE 5.9

CALCITE AND GYPSUM SATURATION RELATIONSHIPS FOR COLUMN TEST SOLUTIONS, GUNNISON SUBPILE STUDY 
The alkalinities of the pore volume solution from background columns 1 and 2 were much higher than the alkalinities obtained from the columns ( 3 through 5 ) containing subpile sediment. The alkalinity of the solutions from the background columns dropped steadily, from highs in the 260 to 270 range in the initial pore volumes to lows around 210 to 220 in the later pore volumes (Figure 5.10).

The alkalinity of the column test solutions varied significantly among columns 3 , 4, and 5 (see Table 5.6 and Figure 5.11). The alkalinity of solutions from column 3 increased steadily from a low of $24 \mathrm{mg} / \mathrm{L} \mathrm{CaCO}_{3}$ in the first pore volume to a high of $118 \mathrm{mg} / \mathrm{CaCO}_{3}$ in the last. Unlike the results for column 3 (subpile pit 20), the alkalinity of solutions from column 4 (subpile pit 19) started below $50 \mathrm{mg} / \mathrm{L} \mathrm{CaCO}_{3}$ and climbed very rapidly to the equivalent of well over $150 \mathrm{mg} / \mathrm{L} \mathrm{CaCO}_{3}$. The alkalinity of the solutions from column 5 (subpile pit 22) generally decreased from about $80 \mathrm{mg} / \mathrm{L} \mathrm{CaCO}_{3}$ in the first few pore volumes to $65 \mathrm{mg} / \mathrm{L} \mathrm{CaCO}_{3}$ at about pore volume 16. From pore volumes 16 to 22, the alkalinity remained relatively constant.

\subsubsection{Major and minor constituents}

Selected pore volumes were analyzed for major and minor constituents (see Table 5.6). Plots of concentration versus pore volume number indicate that some of these constituents (for example, magnesium, chloride, and potassium) decrease in concentration systematically, from the first pore volume to the last, in all of the columns (Figure 5.12). Although sodium concentrations have generally increased in the latter pore volumes (Figure 5.12), this may have been the result of the addition of $\mathrm{NaHCO}_{3}$ to the influent ground water.

Calcium and sulfate behaved differently in the column tests from any of the other major or minor constituents. The concentrations of both calcium and sulfate remained relatively stable for the first 15 to 20 pore volumes from columns 4 and 5 . In column 3, however, the concentrations of calcium and sulfate dropped precipitously within the first five pore volumes and rapidly approached background levels (Figure 5.12).

Iron concentrations were found to be near or below the detection limit in all of the column solutions, except some from column 5 (subpile pit 22). In column 5 , iron concentrations dropped abruptly from a high of over $4 \mathrm{mg} / \mathrm{L}$ in pore volume 2 to near the detection limit by pore volume 10 (Figure 5.12).

Manganese concentrations were elevated above detection limits in some of the pore volume solutions from all of the columns. Although column 5 produced solutions with higher concentrations than those found in columns 3 and 4 , all three columns had elevated levels of manganese in the first five pore volumes (Figure 5.12). The manganese concentrations in the column 3 (subpile pit 20) solution dropped off much more rapidly than did solutions from columns 4 (subpile pit 19) and 5 (subpile pit 22). 

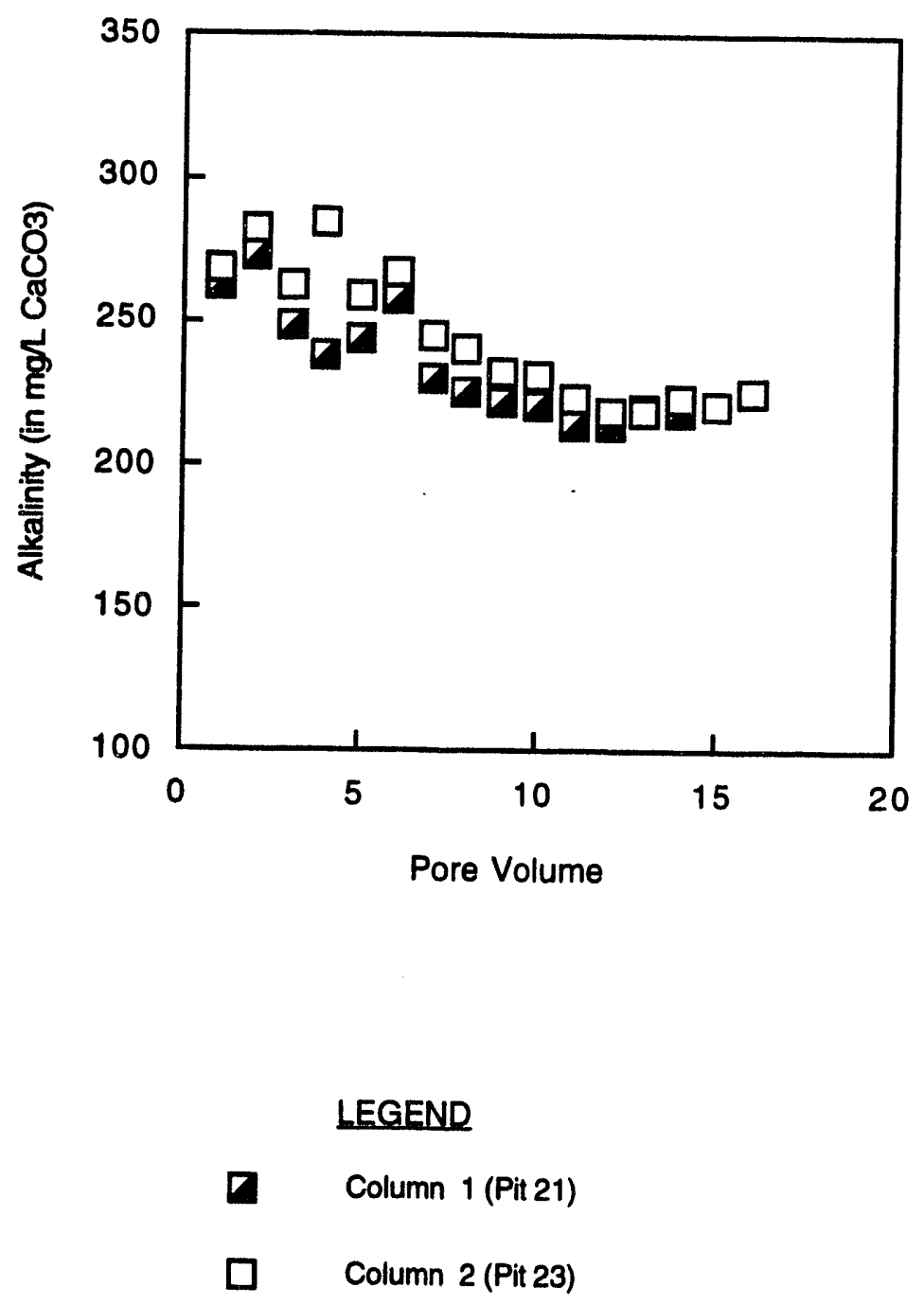

FIGURE 5.10

BACKGROUND ALKALINITY VERSUS PORE VOLUME 


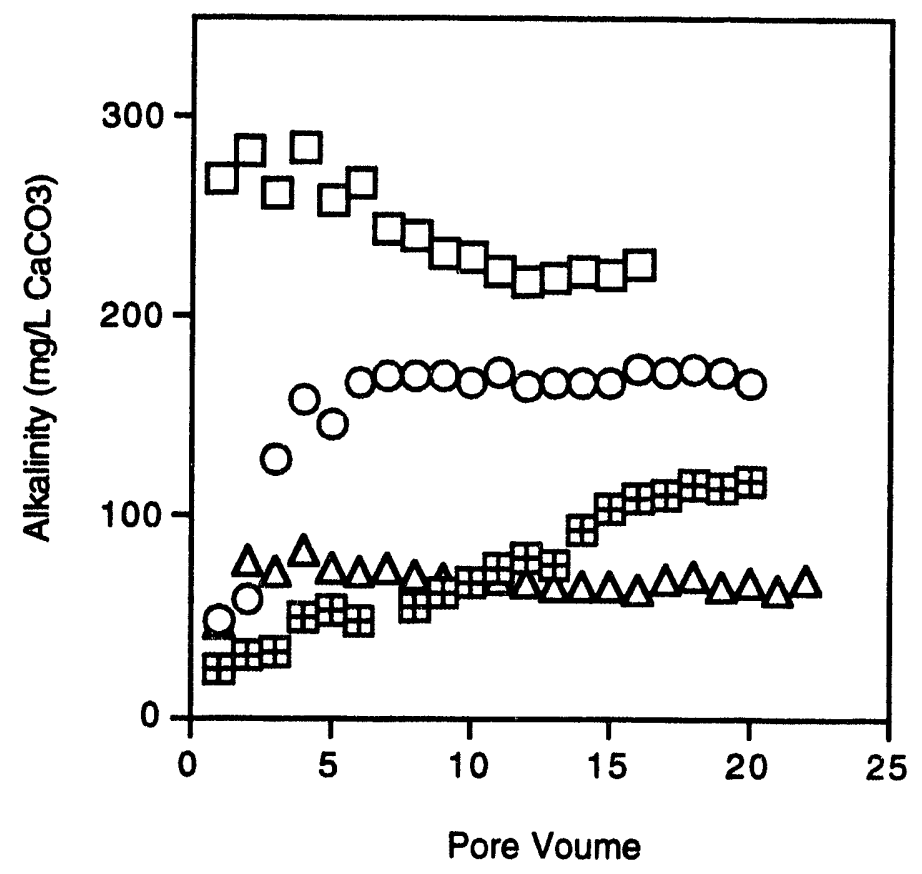

LEGEND
$\square \quad$ (a) Column 2 (Pit 23)
田 (b) Column 3 (Pit 20)
(b) Column 4 (Pit 19)
$\Delta \quad$ (b) Column 5 (Pit 22)

(a) Background sediments

(b) Subpile sediments 


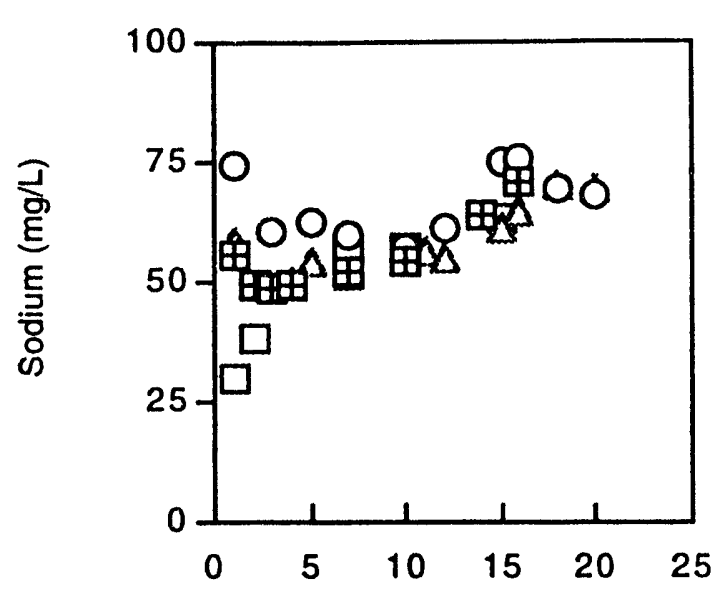

Pore Volume

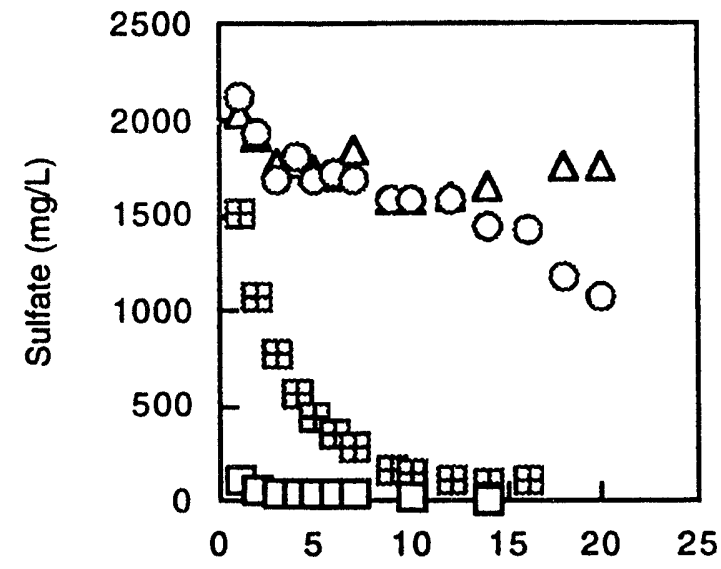

Pore Volume

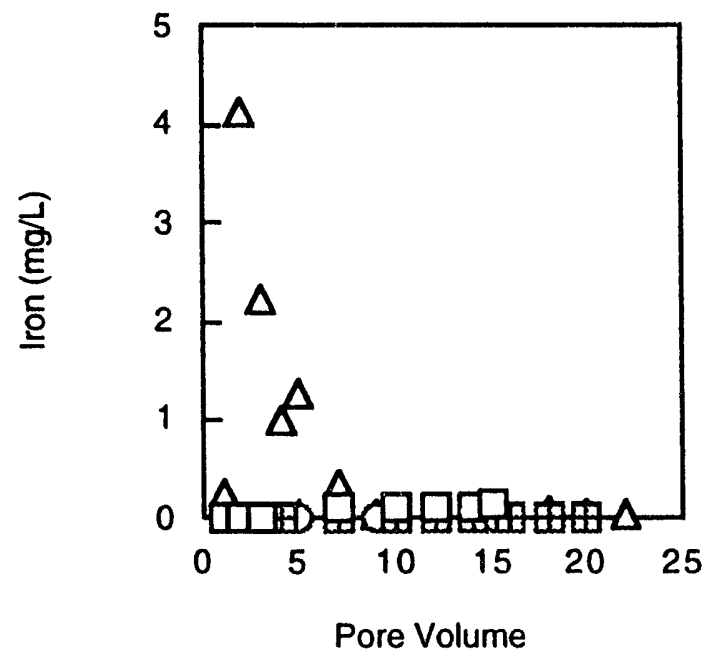

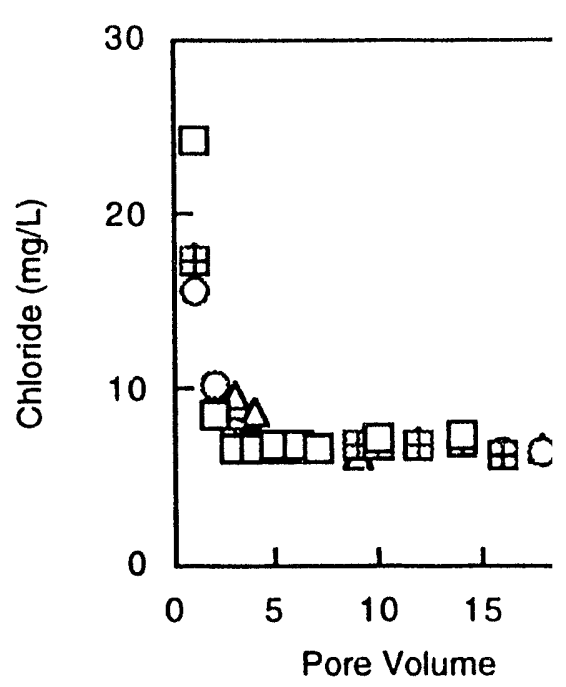
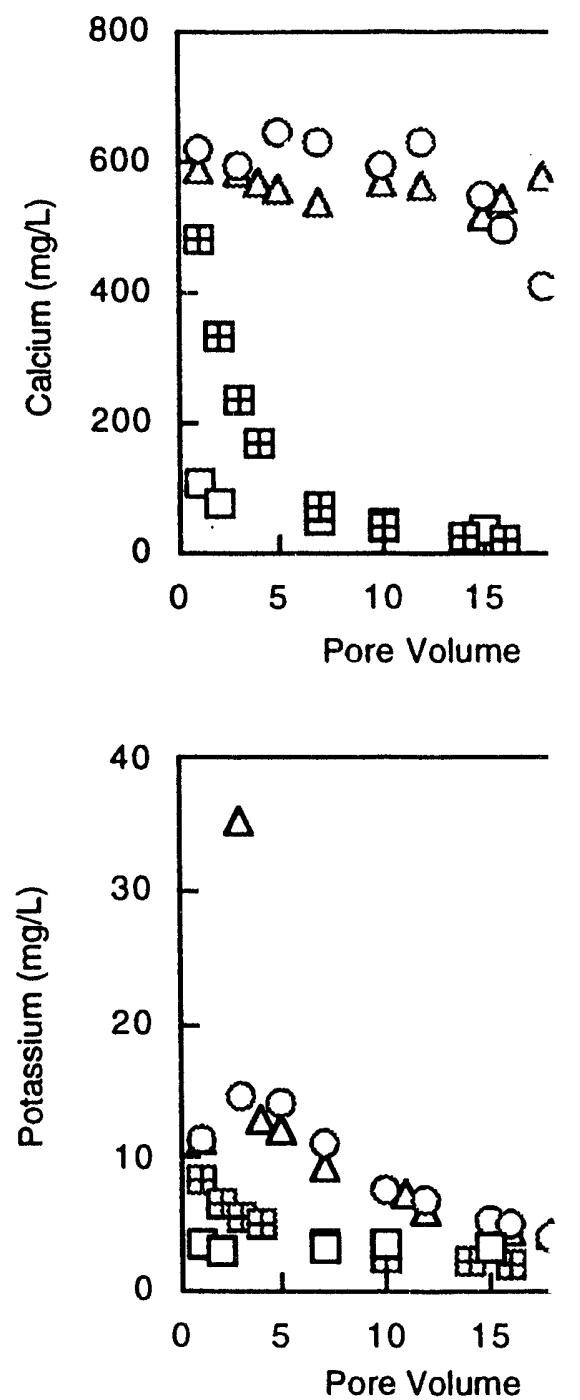


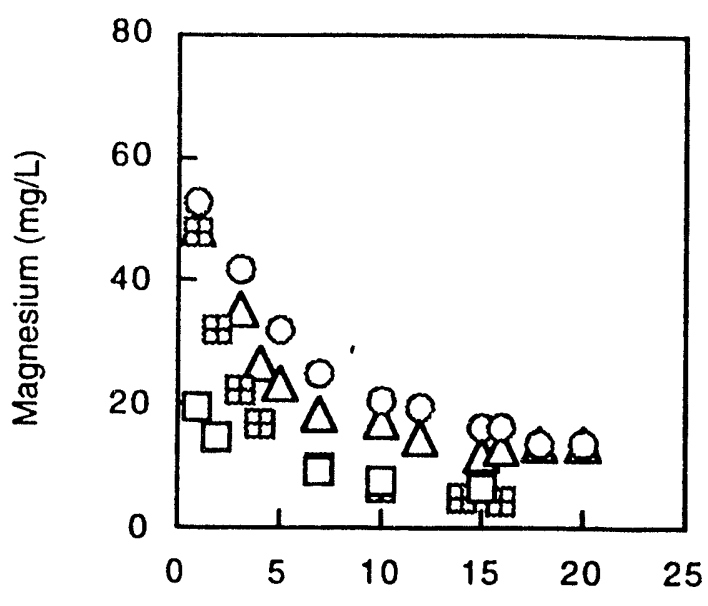

$20 \quad 25$

Pore Volume

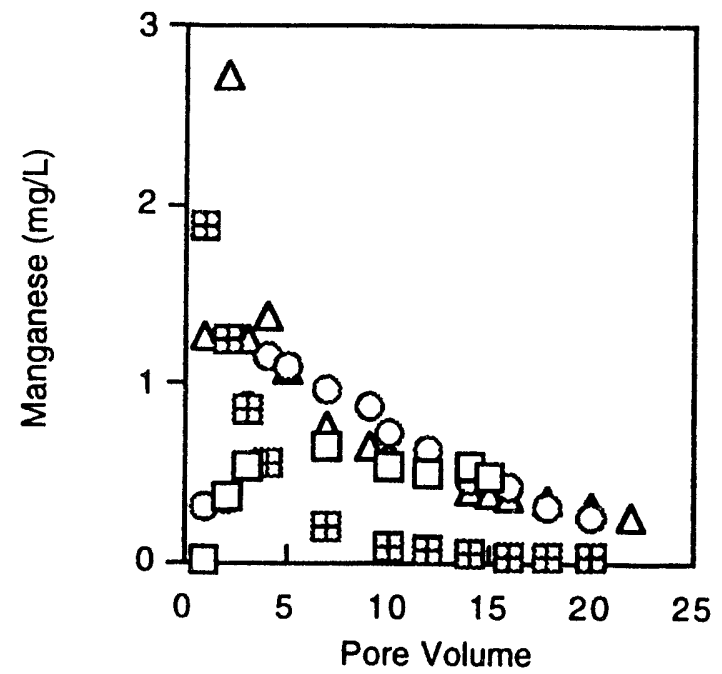

LEGEND

$\square \quad$ (a) Column 2 (Pit 23)

(8) (b) Column 3 (Pit 20)

(b) Column 4 (Pit 19)

$\Delta \quad$ (b) Column 5 (Pit 22)

(a) Background sediments

(b) Subpile sediments 


\subsubsection{Irace constituents}

Several trace constituents (arsenic, cadmium, zinc, molybdenum, uranium, and Th-230) were determined by the analysis of method 3050, total dissolution, and batch test solutions to be significantly elevated above background levels in the subpile sediments (pits 20,19,22). Consequently, column tests were used to evaluate the mobility of these constituents should the ambient pore water conditions in the subpile sediments gradually change from acidic to alkaline. Plots of concentration versus pore volume number illustrate some similarities and differences in the behavior of these trace constituents (Figure 5.13). The concentrations and relative mobility of these constituents in the column test solutions are discussed below.

Despite their elevated concentrations or activities in some of the subpile sediments (see Tables 5.1 and 5.2), arsenic and Th-230 show no evidence that they were mobilized to any significant degree by the influx of alkaline ground water (see Figure 5.13 and Table 5.7). However, the trace constituents cadmium, zinc, molybdenum, and uranium were solubilized to varying extents from the subpile sediment upon interaction with the background ground water influent (see Figure 5.13). Columns 4 and 5 generally showed greater concentrations of these constituents than did column 3 (subpile pit 20). Column 5 (subpile pit 22) desorbed higher concentrations of zinc, molybdenum, and cadmium than did column 4 (subpile pit 19), which desorbed higher concentrations of uranium. The concentrations of zinc and uranium that desorbed were significantly higher than the concentrations of the other trace constituents (see Figure 5.13).

Table 5.7 Column test-composite thorium-230 results for subpile test pits

\begin{tabular}{cccccc}
\hline Location & Column & $\begin{array}{c}\text { Compsite samples) } \\
\text { Pore volumes }\end{array}$ & $\begin{array}{c}\text { Th-230 } \\
\text { (pCi/L) }\end{array}$ & $\begin{array}{c}\text { Value } \\
\text { uncertainty }\end{array}$ & $\begin{array}{c}\text { Detection } \\
\text { limit }\end{array}$ \\
\hline Pit 20 & 3 & $1-5$ & 2.7 & 1.7 & 2.5 \\
& 3 & $6-10$ & 1.0 & 0.6 & 0.8 \\
& 3 & $11-16$ & 0.7 & 0.7 & 0.9 \\
Pit 19 & 3 & $17-20$ & 1.1 & 0.7 & 0.4 \\
& 4 & $1-6$ & 1.1 & 0.8 & 1.3 \\
& 4 & $7-12$ & 2.5 & 1.4 & 0.8 \\
Pit 22 & 4 & $13-19$ & 0.7 & 0.6 & 0.8 \\
& 5 & $1-5$ & 1.3 & 0.9 & 1.0 \\
& 5 & $6-10$ & 1.4 & 0.8 & 0.8 \\
& 5 & $11-15$ & 0.8 & 0.6 & 0.5 \\
& 5 & $16-21$ & 0.5 & 0.5 & 0.8 \\
\hline
\end{tabular}



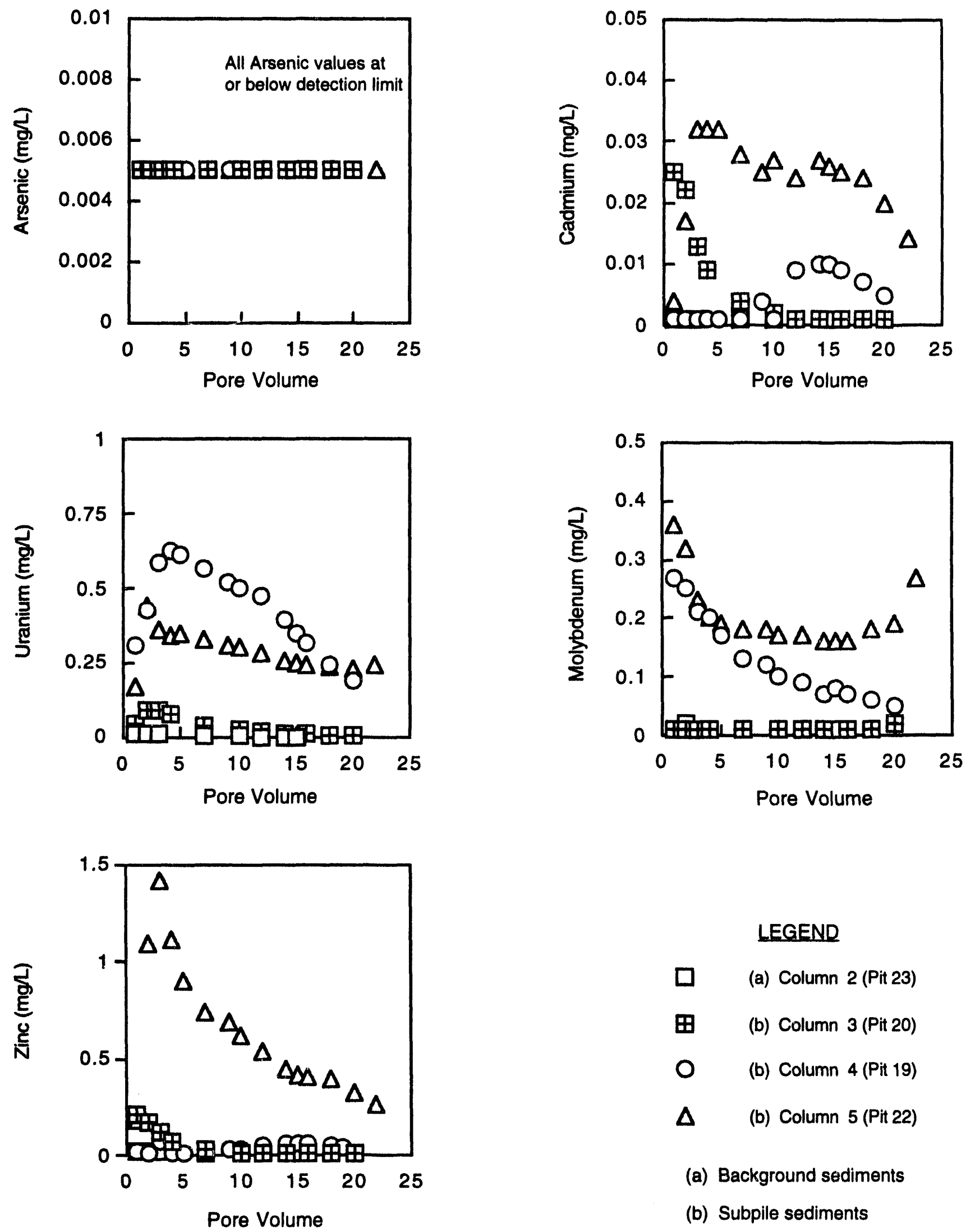

\section{LEGEND}

(a) Column 2 (Pit 23)

田 Column 3 (Pit 20)

(b) Column 4 (Pit 19)

$\Delta \quad$ (b) Column 5 (Pit 22)

(a) Background sediments

(b) Subpile sediments

FIGURE 5.13

CONCENTRATIONS OF TRACE CONSTITUENTS VERSUS PORE VOLUME 
Although concentrations of soluble trace constituents were typically highest in the first few pore volumes and gradually decreased as more pore volumes passed through, there were some exceptions to this general trend. In the effluent of column 4, the concentrations of cadmium and zinc were very low in the first five pore volumes. After about pore volume 5 , the concentrations of these two constituents eluted from column 4 climbed slightly until about pore volume 15, then decreased significantly from pore volume 16 until the experiment ended (Figure 5.14).

Molybdenum concentrations were found to be near or below the detection limit in column 3 (subpile pit 20) solutions, and significantly elevated above background in the effluent of columns 4 (subpile pit 19) and 5 (subpile pit 22). Unlike cadmium and zinc, molybdenum concentrations in column 4 decreased steadily from pore volumes 1 through 20 (see Figure 5.13). In column 5 , however, molybdenum concentrations started high and decreased until about pore volume 15. After pore volume 16, molybdenum concentrations gradually increased until the end of the experiment. 

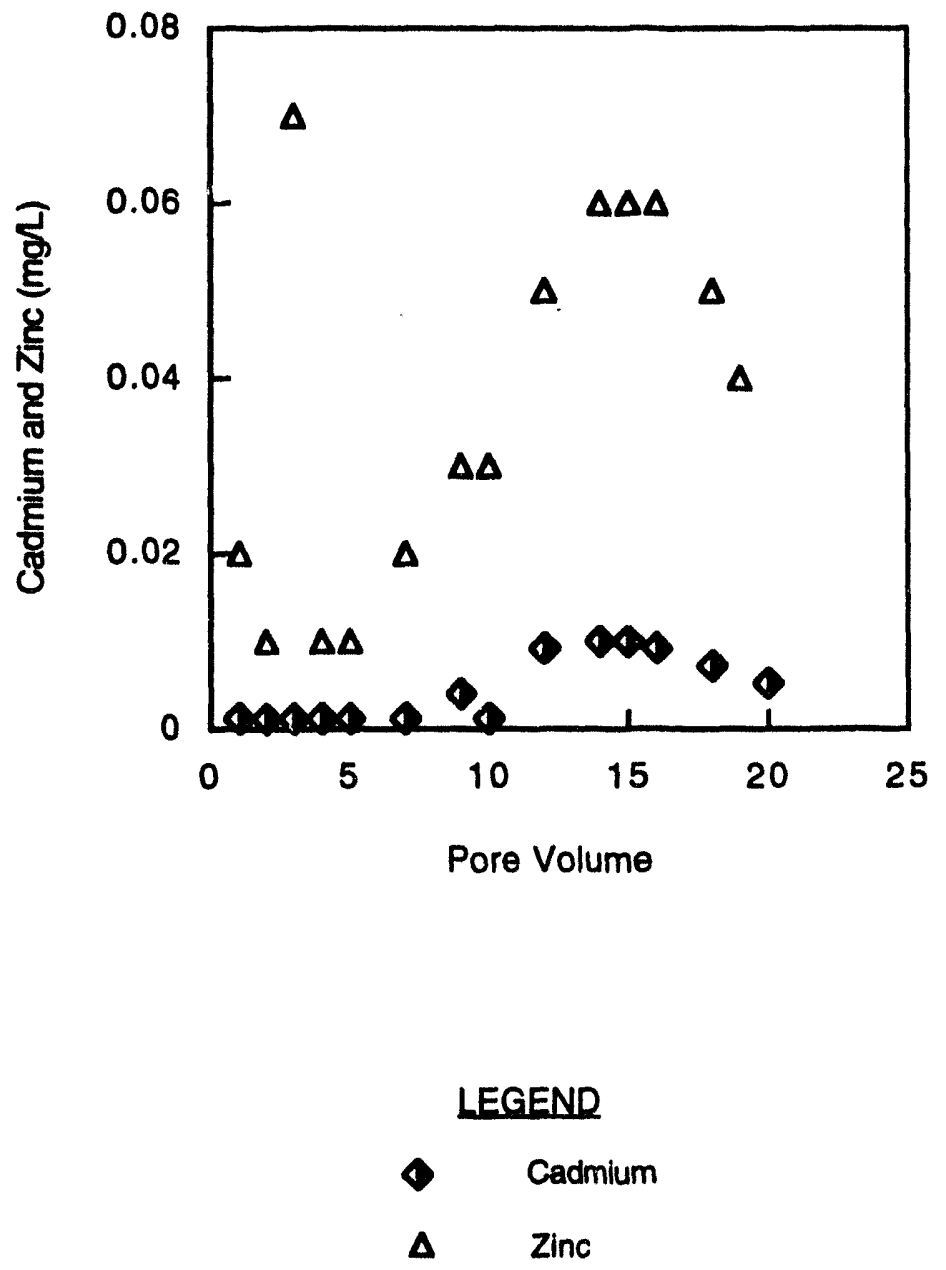

FIGURE 5.14

COLUMN 4 (SUBPILE PIT 19) CADMIUM AND ZINC CONCENTRATIONS VERSUS PORE VOLUME 


\subsection{DISCUSSION}

In the preceding sections, we have attempted to describe the chemical characteristics of the subpile sediments as determined by a series of diagnostic tests. This section integrates these data into a conceptual model that will allow us to explain the various chemical characteristics we have observed. The identification of the processes that control the distribution, solubility, and mobility of the hazardous constituents in the subpile sediments allowed us to determine whether the subpile sediments could have a significant impact on ground water quality at the Gunnison processing site. Potential reasons for the chemical differences observed in the method 3050, column, and batch test solutions for the three on-site test pits are discussed below.

A comparison of the batch test and method 3050 results for the subpile sediment from all three subpile test pits $(19,20$, and 22) indicates that as long as the final pH of the batch test solution was acidic, samples with elevated method 3050 metals concentrations would also produce batch test solutions with elevated metals concentrations. Batch test solutions with a final pH above 5.0 were found to contain much lower concentrations of metals, regardless of the method 3050 concentrations. This suggests that although the absolute concentration of a metal in the sediment is important, $\mathrm{pH}$ is the master variable that controls the solubility of many of the contaminants in the subpile sediments.

Most of the trace metals solubilized in the low-pH batch test solutions are also associated with elevated levels of iron and manganese. Given the paucity of potentially sorptive clay-sized material in the subpile sediments (Table 4.2) and the high affinity of iron and manganese hydroxides for many trace metals (Rai and Zachara, 1984), it is likely that these phases are the largest reservoirs of easily soluble trace metals in these sediments.

The mill at Gunnison operated from 1958 until 1962 and iron and manganese hydroxides have been deposited in the subpile sediments by infiltrating acidic tailings pore water for over thirty years. Consequently, the iron- and manganese-rich coatings on these sediments have built up gradually over this time. Trace metals associated with these coatings were also deposited over 30 years and are not, therefore, simply adsorbed to the present-day surface of these coatings. Trace metals should be found throughout the three dimensional framework of these solid phases. To solubilize those trace metals sequestered within the framework of the coatings, the coatings themselves must be dissolved. As our experiments and tests have demonstrated, however, iron and manganese hydroxides (and most of the associated trace metals) will only be significantly solubilized under acidic groundwater conditions.

Soil pH and acidity titration measurements have demonstrated that some of the subsoil sediments in columns 3 (subpile pit 20), 4 (subpile pit 19), and especially 5 (subpile pit 22) have been acidified by the infiltration of tailings leachate. Given the batch test results discussed above, it might be expected that acidified sediments would solubilize many constituents in the column tests as well. In fact, significant amounts of many contaminants were solubilized from the subpile sediments during the column tests (see Figures 5.12 and 5.13). Unlike the acidic $(\mathrm{pH} \sim 2.4)$ ground water used in the batch tests, however, the influent solution in the column tests was alkaline and had a pH of 
approximately 8.0 (see Figures 5.4 and 5.5). After passing through the columns the alkalinity and $\mathrm{pH}$ of the effluent solutions were generally lower, although their $\mathrm{pH}$ values never dropped below 6.5 (even column 5) and were typically above 7.0. Given the low solubility of many of the metals in batch test solutions with a final pH above 5.0, we must identify the mechanism(s) that solubilized many of these constituents in the column test solutions. Any chemical or physical model used to explain this behavior must also delineate the differences between the chemical characteristics of the column test solutions produced by subpile columns 3,4 , and 5 . By comparing the unique physical and chemical characteristics of the sediment in each column to the unique chemistry of the resulting column test solutions, we can predict the chemical behavior of the ground water subpile system after the tailings are removed.

The batch test solutions on the column 5 (subpile pit 22) sediments indicate that only the deepest sediment sample collected had enough acid neutralization potential to raise the $\mathrm{pH}$ above 5.0. By comparison, the sediment in column 4 (subpile pit 19) consisted of three parts acidic material (the three shallowest samples collected) and two parts that retained significant $\mathrm{CaCO}_{3}$ and had a relatively high acid neutralization potential (the two deepest samples). Because of these differences, the chemistry of the influent ground water would evolve differently as it passed through these two columns. The soil acidity tests (Attachment B) indicate that the shallow sediment layers in both columns would acidify the initial influent solutions (Figure 5.6). The greater acidity of the column 5 sediments would probably lower the pH of the influent solution more than the initial column 4 sediments would.

Under the low pH conditions generated in the influent solution as it passed through the acidified parts of columns 4 and 5, some of the abundant iron and manganese hydroxides in the sediment were dissolved. Iron and manganese hydroxides in the subpile sediments characteristically have a high affinity for many trace metals (see batch leach data on iron-hydroxide-coated pebbles); thus, we can surmise that elevated levels of zinc, cadmium, arsenic, and uranium would have also been solubilized.

Although the low-pH solutions generated in the initial sections of both columns would solubilize many metals, these low-pH, metals-rich solutions encountered progressively less acidic sediments as they progressed through the columns. In column 5 , the pH of the column solutions would gradually increase through interaction with small amounts of $\mathrm{CaCO}_{3}$ remaining in deeper sediments. In column 4, the high acid neutralization potential of the last two sediment layers, when encountered by the column fluids, would rapidly raise the $\mathrm{pH}$ of the solutions to values typical of equilibrium with calcite (for example, 7.7 to 8.0). Consequently, as the alkalinity and $\mathrm{pH}$ of the acidic column solutions increased, most of the solubilized iron and some of the solubilized manganese would be reprecipitated. This reprecipitation would probably take the form of amorphous oxyhydroxides. This process would also remove solution the bulk of those trace constituents that do not form stable aqueous complexes under alkaline or high pH conditions, and that have a very high affinity for iron and/or manganese hydroxides (for example, cadmium, zinc, thorium, and arsenic).

Modeling of column 4 and 5 pore volume solutions with the geochemical code PHREEQE (Parkhurst et al., 1980) indicates that column 4 effluent solutions were saturated with 
respect to calcite, while most of those of column 5 were not (see Figure 5.9). The greater acidity of the column 5 sediments and the lower final pH of the test solutions are the most reasonable explanations for the higher concentrations of iron, cadmium, and zinc in the initial pore volume solutions from this column relative to column 4 (see Figures 5.12 and 5.13). This occurred despite the comparable or higher method 3050 iron concentrations and the higher method $\mathbf{3 0 5 0}$ and batch test cadmium and zinc concentrations found in column 4 sediment (see Tables 5.1 and 5.4).

Unlike columns 4 and 5, none of the column 3 (subpile pit 20) sediments appeared to contain appreciable calcite and all were mildly acidic (Attachment B). The moderate acidity of these sediments initially consumed most of the alkalinity of the influent ground water and produced effluent solutions undersaturated with calcite (see Figure 5.9), though probably not lowering the $\mathrm{pH}$ much below 5. If the $\mathrm{pH}$ attained at any point during the passage of the pore volume solutions through column 3 did not drop below approximately 5.0, comparatively little iron, manganese, uranium, cadmium, or zinc would have been solubilized. This interpretation is supported by the detection of relatively low concentrations of iron, manganese, and the trace metals in first few pore volumes from column 3.

As all three subpile column tests proceeded, the high $\mathrm{pH}$, alkaline influent solution progressively lowered the acid-generating capacity of the acidic sediments. The rate of acid neutralization varied significantly between columns 3,4 , and 5 , depending upon the relative acidity or alkalinity of the sediments.

Unlike the trends observed in columns 3 (subpile pit 20) and 4 (subpile pit 19), the alkalinity of the pore solutions in column 5 (subpile pit 22) generally decreased over time, if only slightly. This suggests that the acid neutralization potential of the less acidic sediments in column 5 may have been nearly exhausted by the end of the experiment due to the influx of acidic solutions generated by the large mass of acidic sediments in this column. Nevertheless, with few exceptions, progressively smaller amounts of iron, manganese and associated trace constituents were solubilized as the tests proceeded. The exhaustion of the acidity in the shallowest, most acidic subpile sediment, not the exhaustion of the reservoir of contaminants in the sediment, produced the general reduction in the concentrations of most constituents in the column tests solutions.

As previously discussed, the cadmium and zinc concentrations in column 4 started low, increased slightly, then decreased again (see Figure 5.14). Although these concentrations were much lower than the levels of cadmium and zinc eluted from column 5 (see Figure 5.13), the dissimilar shape of the elution patterns between column 4 and columns 3 and 5 is puzzling.

The presence of these slightly elevated concentrations of zinc and cadmium in the middle pore volumes can be explained by two different mechanisms: 1) the solubility of these metals increased during the middle pore volumes of the column 4 test; or 2) these small pulses of cadmium and zinc were desorbed from the sediment in the first few pore volumes of the column tests and their movement out of the column was retarded by subsequent interactions with the sediment. 
There was no measurable decrease in the $\mathrm{pH}$ or alkalinity of the column 4 (subpile pit 19) pore volumes over the range in question that could explain this temporary increase in zinc and cadmium solubility. Geochemical modelling with PHREEOE (Parkhurst et al., 1980) confirms that the pore volumes with cadmium values above the detection limit are oversaturated with octavite $\left(\mathrm{CdCO}_{3}\right)$, one of the primary controls on cadmium concentrations in alkaline soils (Rai and Zachara, 1984). This suggests that the elevated levels of cadmium (and by analogy, zinc) simply represent a breakthrough of these metals after solubilization in the acidic part of the column earlier in the experiment (that is, the second explanation given above).

Two trace elements, uranium and molybdenum, behaved quite differently in the column tests than did iron, manganese, and other trace elements discussed above. The behavior of uranium and molybdenum, respectively, is discussed below.

\section{Uranium}

Despite the greater mass of acid sediments in column 5 (subpile pit 22), the effluent of column 4 (subpile pit 19) has the highest concentrations of uranium (see Figure 5.13). Furthermore, unlike its effect on iron, manganese, zinc, and cadmium, the higher $\mathrm{pH}$ of the effluent in column 4 did not rapidly reduce the concentrations of soluble uranium.

Uranium forms relatively stable carbonate complexes in high $\mathrm{pH}$, alkaline ground water (Hsi and Langmuir, 1985). Therefore, a high percentage of the uranium solubilized in the acidic part of column 4 would remain in solution if the alkalinity and pH were increased rapidly. An increase in the $\mathrm{pH}$ without a concomitant increase in the alkalinity, as occurred in column 5, would not promote the formation of relatively mobile carbonate species of uranium. Ultimately, the low alkalinity of these solutions would result in a greater degree of uranium readsorption onto iron hydroxides in column 5 . The greater solubility of uranium in column 4 is consistent with the higher alkalinity of the column 4 effluent solutions (see Figure 5.11).

\section{Molvbdenum}

The apparent increase in molybdenum concentrations in the last few pore volumes of column 5 (subpile pit 22) is not mimicked by any other trace element tested. Three possible explanations for this behavior are listed and evaluated below:

1. The upswing in molybdenum concentrations in column 5 effluent may have been due to the desorption of this constituent from iron hydroxides under elevated $\mathrm{pH}$ conditions. Although the absolute concentrations of molybdenum were considerably higher in the sediments of column 5 , the same pattern of increased molybdenum solubility should have been generated in the latter pore volumes of columns 3 and 5 , if an elevated $\mathrm{pH}$ alone were driving this process. However, there was little evidence of increased mobility of molybdenum in the latter pore volumes of columns 3 or 4 where the pH was significantly higher than in column 5.

2. The slight but steady decrease in the alkalinity of the column effluent from column 5 suggests that the acid neutralization potential of the nonacidic sediments is nearing 
exhaustion. This would allow the low-pH, metals-enriched solutions generated in the acidic parts of the column to migrate closer to the end of the column before neutralization. Although the ability of this column to retard the movement of all the pH-sensitive elements should be progressively lowered by this process, the mobility of molybdenum in solution at nonacidic pH levels should enable this constituent to be the first to break through.

3. The increase in molybdenum concentrations may represent a "breakthrough" of molybdenum that was solubilized by low-pH conditions in the acidic sediments and that had been slowly migrating down the column. In this scenario, the behavior of molybdenum is analogous to that of zinc and cadmium in column 4 , where the concentrations of these two constituents began to increase in the middle pore volumes, peaked, and then began to decrease rapidly in the last few pore volumes.

Although molybdenum is not readily adsorbed onto iron hydroxides if the solution pH rises above 7.0, once adsorbed onto an iron hydroxide (under low or high pH conditions), it is thought to form (over timo) a relatively insoluble ferric molybdate (Rai and Zachara, 1984). Molybdenum in this form is essentially immobile under neutral pH conditions, and in order to mobilize a significant amount of it from the subpile sediments, abundant iron hydroxide and ferric molybdate must be dissolved. Once the acidity in the shallow sediments is exhausted by the influx of alkaline ground water, the iron and manganese hydroxides will not solubilize and the bulk of the associated molybdenum will remain essentially immobile. 


\subsection{SUMMARY}

It is clear from the data presented that the chemistry of the subpile sediments is complex. Concentrations of many constituents vary significantly from one on-site test pit to another (for example, arsenic). These variations are probably largely due to local variations in the volume and contaminant load of the tailings pore fluid that entered the subpile sediments sampled by the on-site test pits. Furthermore, subpile sediments having similar total concentrations of certain other constituents (for example, iron and uranium) within and between these test pits commonly yield widely variable concentrations when subjected to batch and column tests under the same conditions.

The paucity of clay-sized material in these sediments (Table 4.2) suggests that the natural sorptive capacity of these sediments is dominated by iron and manganese hydroxides. The strong association of many trace metals with elevated levels of ircn and manganese in the batch tests (including the pebbles) supports the inference that the iron and manganese hydroxides are the largest single reservoir of these trace metals in the subpile sediments.

For over thirty years at this site, iron and manganese hydroxides have been deposited in the subpile sediments by infiltrating tailings pore water. The iron- and manganese-rich coatings on these sediments have built up gradually over this period of time, with the associated trace metals not simply adsorbed to the surface but distributed throughout the three-dimensional framework of the iron and manganese hydroxides. To solubilize the trace metals sequestered within the framework of the coatings, the coatings themselves must be dissolved. This is particularly true for molybdenum that, once adsorbed onto iron hydroxides, forms the stable phase ferric-molybdate (Rai and Zachara, 1984).

The fundamental variables that appear to coritrol the solubility of the various contaminants within the Gunnison subpile sediments are 1) the acidity or alkalinity of the sediments; 2) the absolute concentrations of the contaminants in the sediments; 3 ) the final $\mathrm{pH}$ and alkalinity of the ground water; and 4) the chemical properties of the contaminants. The interplay of these variables produces disparate levels of contamination emanating from the sediments of the three on-site test pits. For those metals that are insoluble at high pH levels, the relative acidity of the differing colımn sediments is more critical to producing elevated concentrations in the column test solutions than is the absolute amount of the constituent present. For those metals that stay in solution under alkaline and high pH conditions once mobilized by initially acidic conditions (molybdenum and uranium), the total concentration present on the sediment is also an important factor.

Uranium and molybdenum are the only two hazardous constituents evaluated that could potentially be transported in significant amounts from the low-pH subpile sediments into the alkaline, high-pH ground water outside the immediate area of the subpile sediments. Unlike uranium, however, molybdenum is not a significant ground water contaminant at Gunnison and has been found at concentrations consistently above background levels in only one well (completed in the shallow alluvial sediments beneath the pile). This suggests that molybdenum will not be a problem for ground water quality after surface remediation. The much larger uranium problem at Gunnison is due, in large part, to the much higher concentrations of uranium that are solubilized from the tailings and from the acidic subpile sediments. 
This study has demonstrated that the extent of groundwater contamination that should occur if all the subpile sediments were exposed to long term saturated conditions is relatively small. If (as is expected) the acidic subpile sediments left in place after surface excavation at Gunnison remain above the water table, any threat to future ground water quality should be even less. The acidity present in the remaining sediments will be slowly dissipated (as occurred in the subpile pit 20 sediments) by the long term infiltration of precipitation into and through the unsaturated zone. Metals that are solubilized during this slow process will be greatly attenuated by interactions with the less-acidic and alkaline sediments present below the acidic sediments but above the water table. The flux of uranium and other contaminants to the saturated section would certainly be much smaller than the flux under the saturated, worst case scenario conditions evaluated in this study. Dilution of this small flux of contaminated water from the unsaturated subpile sediments by the much greater flux of the Gunnison alluvial aquifer should quickly drop uranium (and any other contaminant) concentrations to background levels. 


\subsection{CONCLUSIONS}

The results of this study suggest that if, in the unlikely event, the ground water table at the Gunnison processing site were to rise and stay 3 to $6 \mathrm{ft}(1$ to $1.8 \mathrm{~m})$ above current levels (saturating the entire pre-excavation subpile section), the following processes would occur:

- Ground water equilibrating with the upper 1 to $3 \mathrm{ft}(0.3$ to $0.9 \mathrm{~m})$ of the subpile (preexcavation) sediment would be acidified and contaminated with many constituents, such as iron, manganese, arsenic, thorium, zinc, cadmium, molybdenum, and uranium.

- As the acidified ground water moves into $\mathrm{CaCO}_{3}$-bearing sediments and mixes with high-pH, alkaline ground water, the concentrations of all the trace metals discussed above (except uranium and molybdenum) would be greatly attenuated by precipitation and adsorption reactions.

- The acidity of the shallow subpile sediments would be fairly quickly neutralized by infiltrating alkaline water; the iron and manganese hydroxides, and their associated trace elements (including uranium and molybdenum), would become progressively less soluble.

The solubility and concentration of subpile uranium and molybdenum in ground water is controlled by several interrelated factors, including the following:

- The amount of uranium and molybdenum present in the sediment.

- The acidity of the sediments.

- The pH and alkalinity of the water mixed with the subpile sediment.

- The $\mathrm{pH}$ and alkalinity of the contaminated ground water after equilibration with subpile sediment.

Batch and column test data demonstrate that acidic subpile sediments solubilize tens to hundreds of times more uranium than molybdenum. The subpile sediments, therefore, will not be a significant source of molybdenum contamination of ground water.

Batch and column test data demonstrate that acidic subpile sediments solubilize tens to hundreds of times more uranium than alkaline subpile sediments with equal or higher amounts of total uranium. This suggests that nearly all the readily soluble uranium is present in the acidified (typically, the upper 1- to 3-ft [0.3- to 0.9-m]) portion of the subpile sediments.

The mass, acidity, and metals content of the tailings is far higher than that of the subpile sediments. The subpile sediments appear, therefore, to be much less important than the overlying tailings as potential sources of ground water contamination. Once the tailings and radiologically contaminated subpile sediments are removed, the low-pH solutions 
capable of dissolving the uranium-enriched iron and manganese phases would only be generated in the remaining acidified subpile sediments.

Although it would not be necessary under current water table conditions, excavation of the most acidic and uranium-rich subpile sediments would significantly reduce the amount of uranium that would become soluble if the water table were to rise for an extended amount of time to 3 to $6 \mathrm{ft}(1$ to $1.8 \mathrm{~m}$ ) above existing levels. 


\subsection{APPLICATION}

The purpose of this section is to discuss how the :esults of the analyses and evaluation, which led to the conclusions described in Section 8.0, are to be implemented. As discussed in Section 1.0, this study evaluated the potential for a secondary source of ground water contamination following compliance with surface remediation excavation criteria for radium and thorium. The bulk of this study was completed in mid-1993, and a series of meetings with the DOE, CDH, RAC, and TAC were held to discuss the results. Further, evaluation of the data since then has not significantly changed the conservative conclusions reached at that time.

Any potentially soluble secondary source term to ground water contamination would be mitigated by surface remedial action excavation, assuming excavation of subpile materials to a depth of $3 \mathrm{ft}(0.9 \mathrm{~m})$. At this depth, uranium was found to be the most mobile of the contaminants analyzed. Concerns then focused on the depth for radium and thorium contamination and how that depth related to uranium concentrations in the subpile materials. Uranium, Ra-226 and Th-230 were analyzed in the soils collected during the test pitting program for the cobbles-to-fines evaluation (November 1992). The results of these analyses were correlated and it was found that thorium is more mobile than radium at Gunnison. There was good correlation in all but 3 of the test pits (Figure 9.1), whereby excavation of thorium would remove any potential uranium contamination of ground water. The three test pit locations where uranium levels of concern extended deeper than thorium were further evaluated.

As discussed in Section 8.0, soluble (mobile) uranium is found in acidified subpile sediments. Two of the test pits ( 6 and 12) did not contain acidic sediments and significant migration of uranium will not occur. In the third test pit, 16 (see Figure 9.1), the subpile sediments were acidic (see Table B.1) and presented the most significant source of uranium. This potential secondary source of ground water contamination would be eliminated if the subpile sediments were excavated to a depth of $3 \mathrm{ft}(2 \mathrm{~m})$ or to a soil $\mathrm{pH}$ of 5, whichever is less. Consequently, in the area of test pit 16 these criteria will be applied, in addition to the excavation criteria for surface remediation standards (for radium and thorium). No other areas of the tailings pile require additional cleanup standards to remove potential secondary sources of contamination. 


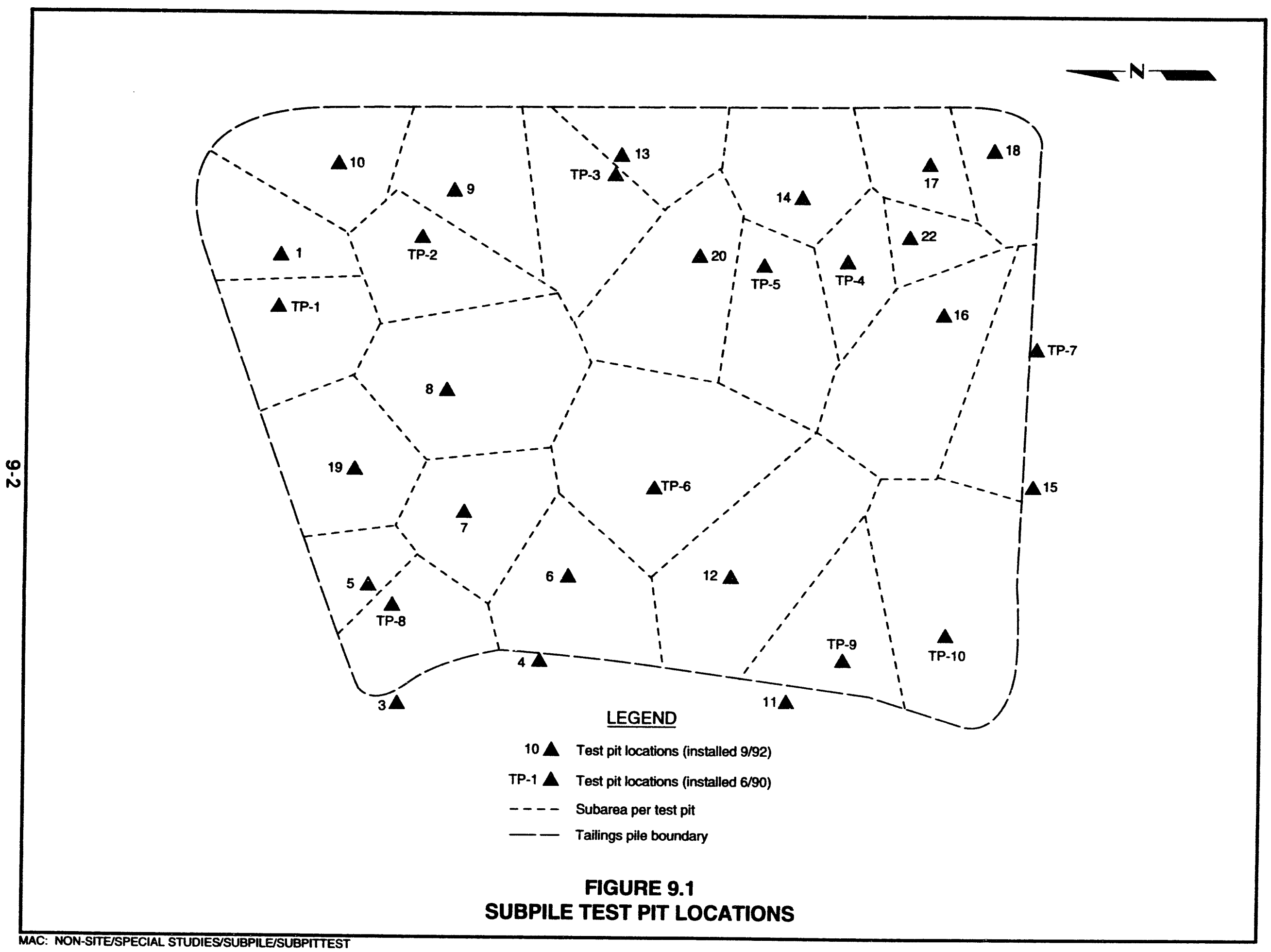




\subsection{LIST OF CONTRIBUTORS}

The following individuals contributed to the preparation of this audit report.

\begin{tabular}{ll}
\hline Name & Contribution \\
\hline J. Blount & Document responsibility and authorship \\
A. Groffman & Co-author and technical assistance \\
J. McBee & Co-euthor \\
K. Monks & Technical assistance \\
L. Keith, C. Slosberg & Text processing \\
D. Anderson & Technical editing \\
\hline
\end{tabular}




\subsection{REFERENCES}

ASTM, 1984. "Distribution Ratios by the Short-Term Batch Method," Method 4319, Soil and Rock, Building Stones; Volume 04.08, ASTM, 1916 Race St., Philadelphia.

DOE (U.S. Department of Energy). 1992. Remedial Action Plan and Site Design for Stabilization of the Inactive Uranium Mill Tailings Site at Gunnison, Colorado, UMTRA-DOE/AL-050508.0000, DOE UMTRA Project Office, Albuquerque Operations Office, Albuquerque, New Mexico.

Hsi, C. D., and D. Langmuir, 1985. "Adsorption of Uranyl Onto Ferric Oxyhydroxides: Application of the Surface Complexation Site-Binding Model," in Geochemica et Cosmochimica Acta, Vol. 49, pp. 1931-1941.

Hunt, C. B., 1967. Physiography of the United States, W. H. Freeman and Company, San Francisco, California.

JEG (Jacobs Engineering Group Inc.), n.d. Albuquerque Operations Manual, standard operating procedures, prepared by Jacobs Engineering Group Inc., Albuquerque, New Mexico, for the U.S. Department of Energy, UMTRA Project Office, Albuquerque Operations Office, Albuquerque, New Mexico.

Parkhurst et al. (D. L. Parkhurst, D. C. Thorstenson, and D. N. Plummer), 1980. PHREEQE-A Computer Program for Geochemical Calculations, U.S. Geological Survey, Water Resources Investigation 80-96, National Technical Information Services Report PB81-167-801, Springfield, Virginia.

Plummer et al. (L. N. Plummer, B. F. Jones, and A. H. Truesdell), 1976. WATEQF: A FORTRAN IV Version of WATEQ, a Computer Program for Calculating Chemical Equilibrium of Natural Waters, User's Guide, U.S. Geological Survey Water Resources Division, USGSMRI-76-13, Reston, Virginia, 61 pp.

Rai, D., and J. M. Zachara, 1984. Chemical Attenuation Rates, Coefficients, and Constants in Leachate Migration, Volume I: A Critical Review, prepared by Battelle-Pacific Northwest Laboratories for EPRI, Palo Alto, California.

\section{CODE OF FEDERAL REGULATIONS}

40 CFR Part 192, Health and Environmental Protection Standards for Uranium and Thorium Mill Tailings, U.S. Environmental Protection Agency, 1993. 


\section{ATTACHMENT A}

LITHOLOGIC LOGS OF TEST PITS 19, 20, 21, 22 AND 23 
ATTACHMENT A

GUNNISON SUBPILE STUDY

LOG OF TEST PIT NO.

DATE 11-10-92

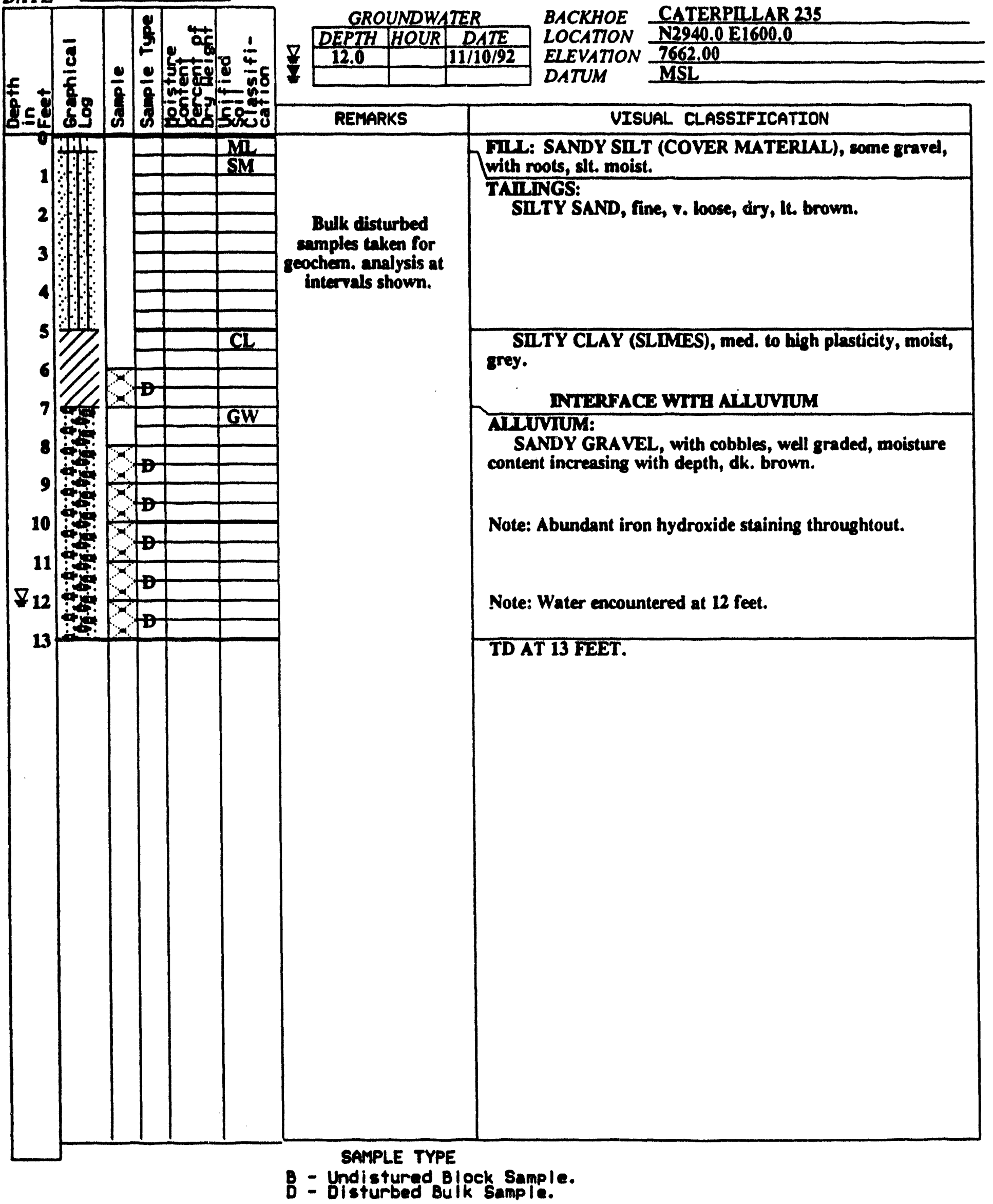




\section{DATE 11-10-92}
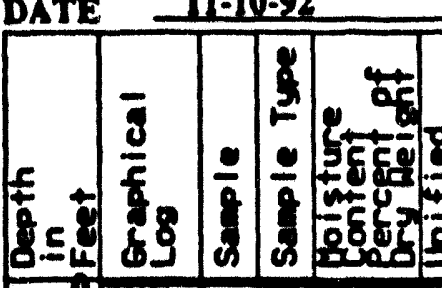

2

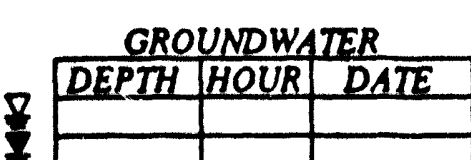

BACKHOE CATERPDLAR 235

LOCATION N2280.0 E2000.0

ELEVATION 7662.00

DATUM MSL

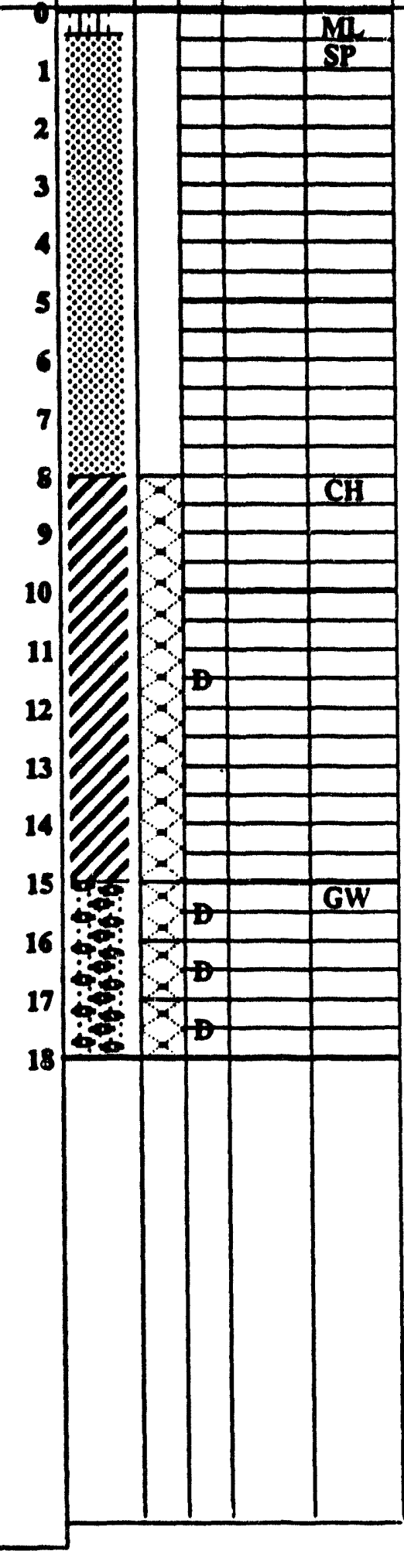

Bulk disturbed enmples taken for geochem. analysis at intervals shown.

- Undistured Block Sample.

- Disturbed Buik Sample.
SILTY CLAY, (SLIMES), high plasticity, moist, greyish green.

\section{NTIERTACE WITH ALCUVIUM}

ALUVIM:

GRA VEL AND COBBLES, some sand, well graded, moist, It. brown to lt. grey.

Note: Moderate iron hydroxide staining throughout.

TD AT 18 FEET. 


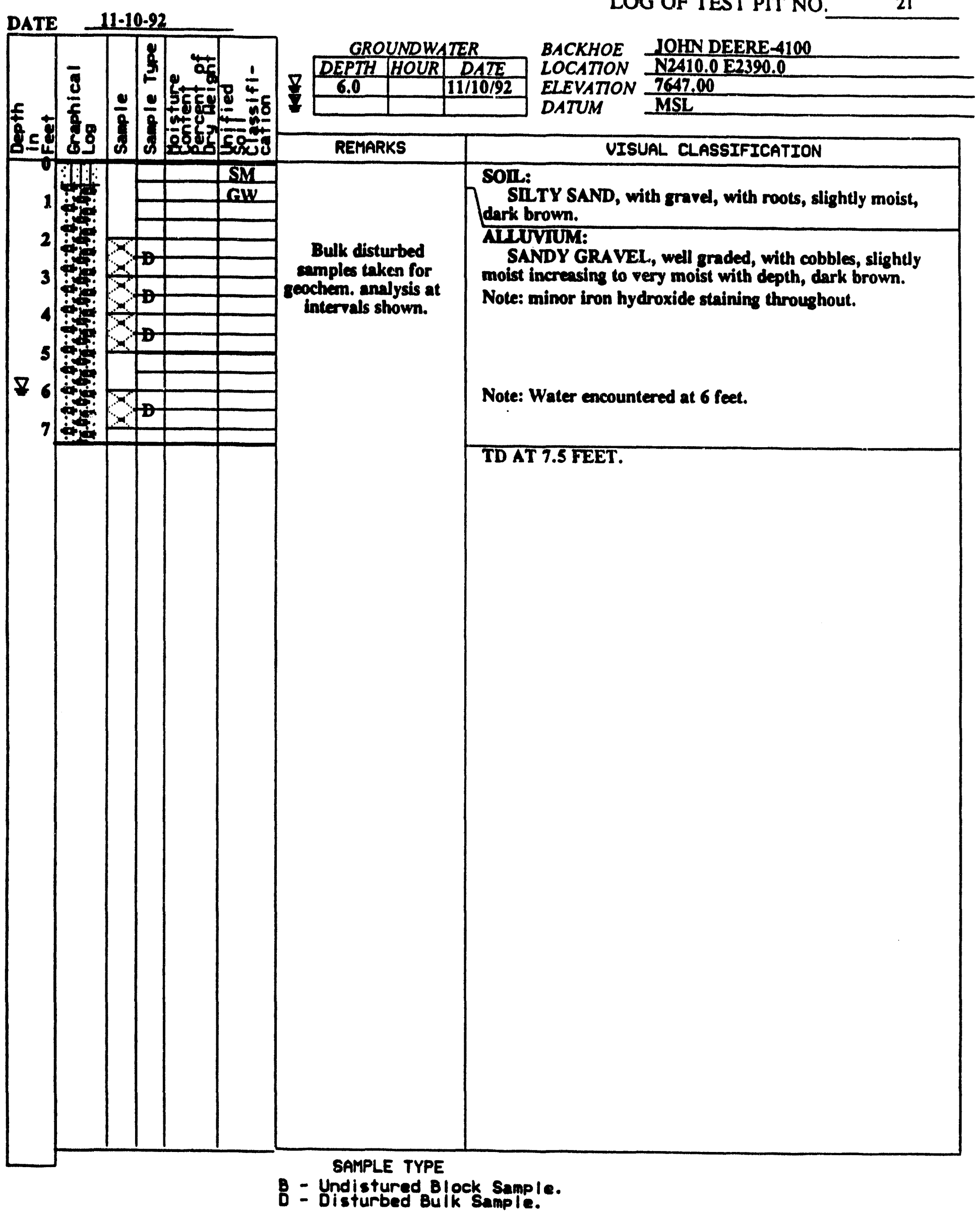




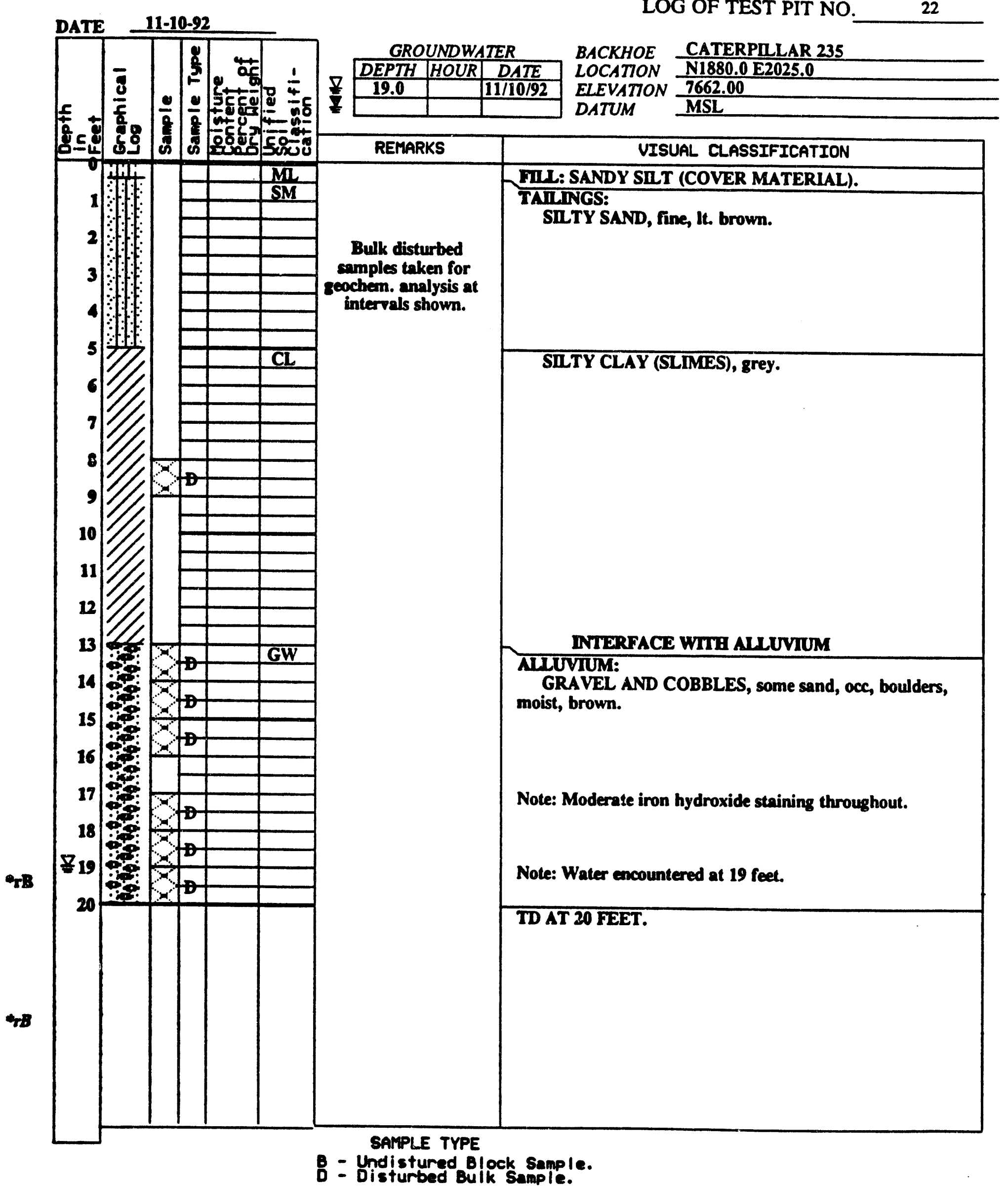

LOG OF TEST PIT NO.

22

DATE 11-10-92

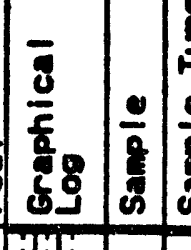

TH HOUR DATE

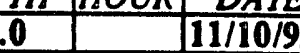

VATION

DATUM MSL

\section{IL: SANDY SLT (COVER MATERIAL)}

ILINGS:

Bulk disturbed amples taken for cochem. analysis at intervals shown.

\section{SILTY CLAY (SLIMES), grey.}

\section{NTORTACE WITH AUUUVUU}

GRAVEL AND COBBLES, some sand, occ, boulders, moist, brown. 
ATTACHMENT A (Continued)

GUNNISON SUBPILE STUDY

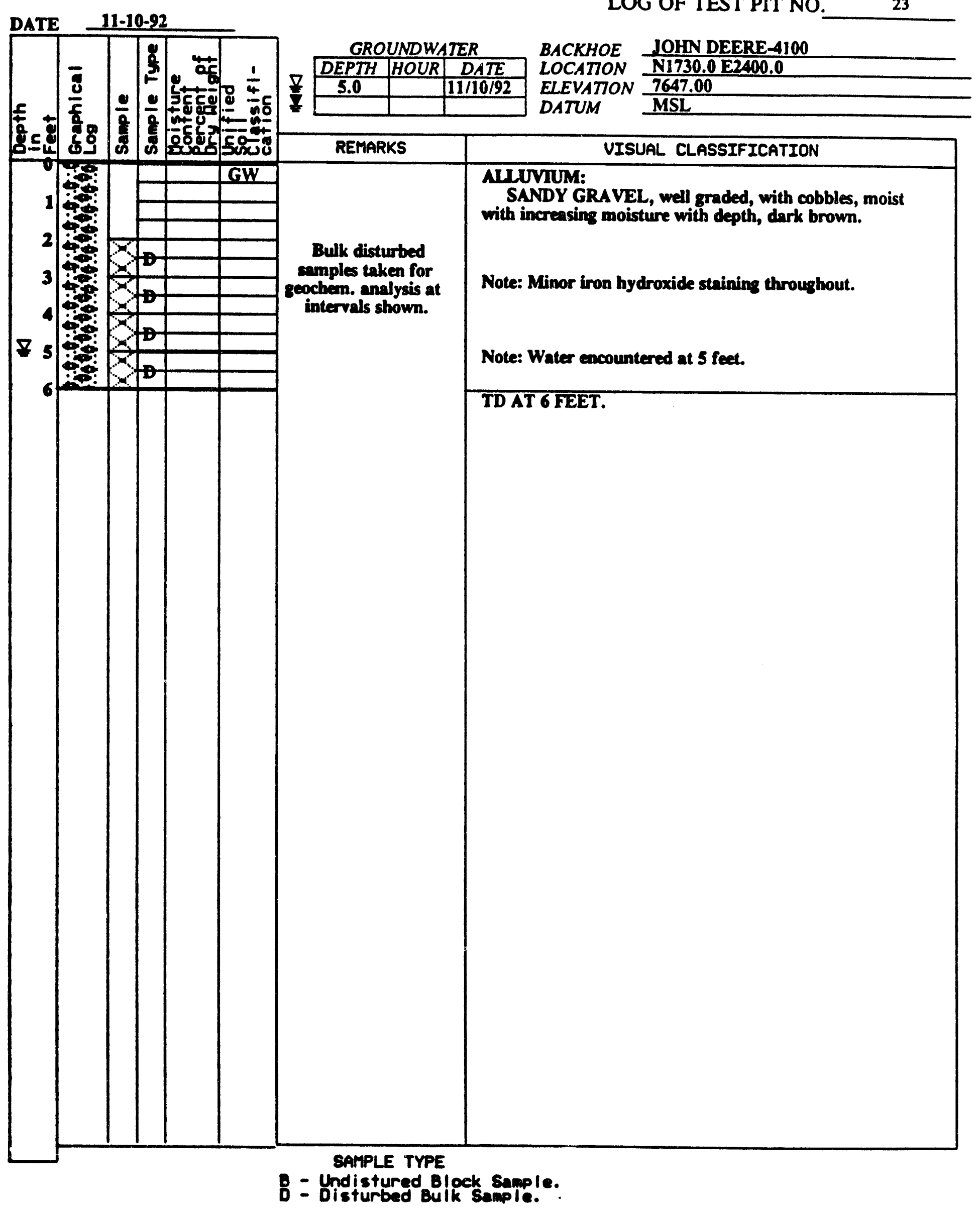


ATTACHMENT B

SOIL ALKALINITY AND ACIDITY MEASUREMENTS 
ATTACHMENT B

\section{SOIL ALKALINITY AND ACIDITY MEASUREMENTS}

The soil alkalinity or acidity of the subpile sediments from the three test pits $(19,20$, and 22) excavated for this study are shown in Table B.1. The results for background test pit 23 and a fourth test pit (16) through the tailings are also presented in this table. Test pit 16 is one of several pits installed by Morrison Knudsen-Ferguson (MK-F) to determine the cobbles-to-fines ratio of the alluvial sediments at Gurinison. No other geochemical analyses were performed on the sediment of this test pit.

The procedure used for determining the alkalinity or acidity of these sediments is as follows:

Twenty-five grams of dried, fine-grained (< \#4 mesh) sediment was mixed with 150 milliliters $(\mathrm{mL})$ of Gunnison background ground water from monitor well 002 in plastic beakers, shaken for 1 minute, and allowed to react overnight. The initial alkalinity of the background ground water used in these tests was analyzed five times during these tests. The values obtained were 112, 115, 104, 115, and 111 milligrams per liter (mg/L) of calcium carbonate $\left(\mathrm{CaCO}_{3}\right)$. After 24 hours, the solutions were decanted and the pH was measured. In those solutions with an initial pH above 4.5 (those with alkalinity), the solution was titrated down to a pH of 4.5 using 1.6 normal $\left(\mathrm{N}^{\mathrm{H}} \mathrm{H}_{2} \mathrm{SO}_{4}\right.$. For those samples where the initial pH were below 4.5 (those that were acidic), the solution was titrated up to a pH of 4.5 with $1.6 \mathrm{~N} \mathrm{NaOH}$. The amount of alkalinity in $\mathrm{mg} / \mathrm{L} \mathrm{CaCO}_{3}$ equivalent is reported in positive numbers in Table B.1. The acidity of the sediments is recorded as "negative" alkalinity; that is, the amount of $\mathrm{NaOH}$ that had to be added to the solution to neutralize the acidity and bring the $\mathrm{pH}$ to 4.5. The negative values in Table B.1 indicate acid conditions.

Although these values are not quantitative in the sense that they measure the total acidity or alkalinity of the sediments, they are useful in examining the relative differences between the sediments within or between the tests pits. Furthermore, these tests indicate that the shallowest sediments in the subpile test pits are sufficiently acidic to consume all the alkalinity of the background ground water at a relatively high solution-to-sediment ratio (6:1). 
Table B.1 Relative soil alkalinity or acidity

\begin{tabular}{|c|c|c|c|c|c|}
\hline \multirow[b]{2}{*}{ Location } & \multirow[b]{2}{*}{ Sample \# } & \multicolumn{2}{|c|}{ Depth } & \multirow[b]{2}{*}{ Soil pH } & \multirow[b]{2}{*}{ Soil alkalinity } \\
\hline & & $(\mathrm{ft})$ & (m) & & \\
\hline \multirow[t]{5}{*}{16} & 1 & 0.5 & 0.15 & 4.23 & -31 \\
\hline & 2 & 1.5 & 0.5 & 4.44 & -2 \\
\hline & 3 & 2.5 & 0.75 & 4.55 & 1 \\
\hline & 4 & 3.5 & 1.0 & 5.1 & 4 \\
\hline & 5 & 4.5 & 1.4 & 6.24 & 19 \\
\hline \multirow[t]{5}{*}{23} & 1 & 2.5 & 0.75 & 7.75 & 112 \\
\hline & 2 & 3.5 & 1.0 & Not tested & Not tested \\
\hline & 3 & 4.5 & 1.4 & Not tested & Not tested \\
\hline & 4 & 5.5 & 1.7 & 7.75 & 110 \\
\hline & 5 & & & Not tested & Not tested \\
\hline \multirow[t]{3}{*}{20} & 2 & 0.5 & 0.15 & 6.76 & 22 \\
\hline & 3 & 1.5 & 0.5 & 7.04 & 43 \\
\hline & 4 & 2.5 & 0.75 & 6.97 & 34 \\
\hline \multirow[t]{5}{*}{19} & 2 & 1.5 & 0.5 & 4.3 & -2 \\
\hline & 3 & 2.5 & 0.75 & 5.24 & 7 \\
\hline & 4 & 3.5 & 1.0 & 7.21 & 75 \\
\hline & 5 & 4.5 & 1.4 & 7.31 & 60 \\
\hline & 6 & 5.5 & 1.7 & 7.55 & 85 \\
\hline \multirow[t]{6}{*}{22} & 2 & 0.5 & 0.15 & Not tested & Not tested \\
\hline & 3 & 1.5 & 0.5 & 4 & -11 \\
\hline & 4 & 2.5 & 0.75 & 4.53 & 0 \\
\hline & 65 & 4.5 & 1.4 & 6.8 & 50 \\
\hline & 6 & 5.5 & 1.7 & 6.84 & 47 \\
\hline & 7 & 6.5 & 2.0 & 7.11 & 65 \\
\hline
\end{tabular}

Note: The amount of alkalinity in $\mathrm{mg} / \mathrm{CaCO}_{3}$ equivalent is reported in positive numbers in Table B.1. The acidity of the sediments is recorded as "negative" alkalinity; that is, the amount of $\mathrm{NaOH}$ that had to be added to the solution to neutralize the acidity and bring the pH to 4.5. The negative values in Table B.1 indicate acid conditions. 
ATTACHMENT C

COLUMN CONSTRUCTION AND EXPERIMENTAL PROCEDURE 


\section{ATTACHMENT C}

\section{COLUMN CONSTRUCTION AND EXPERIMENTAL PROCEDURE}

Column tests, using background water (from monitor well 002) as a leaching agent, were performed on sediment from all five subpile test pits. The pH and alkalinity of the background ground water was measured in the field during collection and periodically in the laboratory. The alkalinity of this water was adjusted in the laboratory, as necessary. to keep it at a higher value than the alkalinity measured for background ground water in the field.

The columns were constructed in the following manner. Layers of test pit material, each lift corresponding to a sampling interval, were packed into 4 by 24 inch (in) (10 $\times 61$ centimeter [cm]) polycarbonate columns. The packing sequence, mass, and height of each lift are shown in Table C.1. The columns were sealed at both ends by 1 in $(2.5 \mathrm{~cm})$ polyvinyl chloride plugs, with a port to allow fluid to enter and exit. A filter system consisting of silica sand resting between glass fiber filters was placed at the top and bottom of the columns to trap particulate material. Figure $\mathbf{5 . 6}$ shows a diagram representing a column used in this study.

Feed solution was distributed to the bottom of the columns in 0.25 -in $(0.64-\mathrm{cm})$ TYGON tubing. The tubing was connected to a 5-gallon (19-liter) NALGENE carboy elevated on a 10-foot (ft) (3-meter [m]) high shelf to provide hydraulic head. The solution was allowed to flow through the column from bottom to the top to effectively degas the sediments, at a specified rate that was controlled by a multichannel MONOSTAT cassette pump. Small diameter $(0.09$ in $[0.24 \mathrm{~cm}])$ TYGON tubing was threaded through the pump cassettes to allow better control of flow through the columns. Effluent from the columns flowed into 100-mL Erlenmeyer flasks, which were sealed with a rubber stopper to prevent evaporation.

Flow through the columns was adjusted to approximately 0.75 foot/day $(0.23$ meter/day) to simulate the average linear velocity of ground water in the alluvial aquifer beneath the tailings pile at Gunnison, Colorado. Flow was controlled by periodically weighing the effluent on a top-loading scale and adjusting individual pump cassettes so that the calculated pore volume for each column was collected within the prescribed time (usually 48 hours per pore volume). 


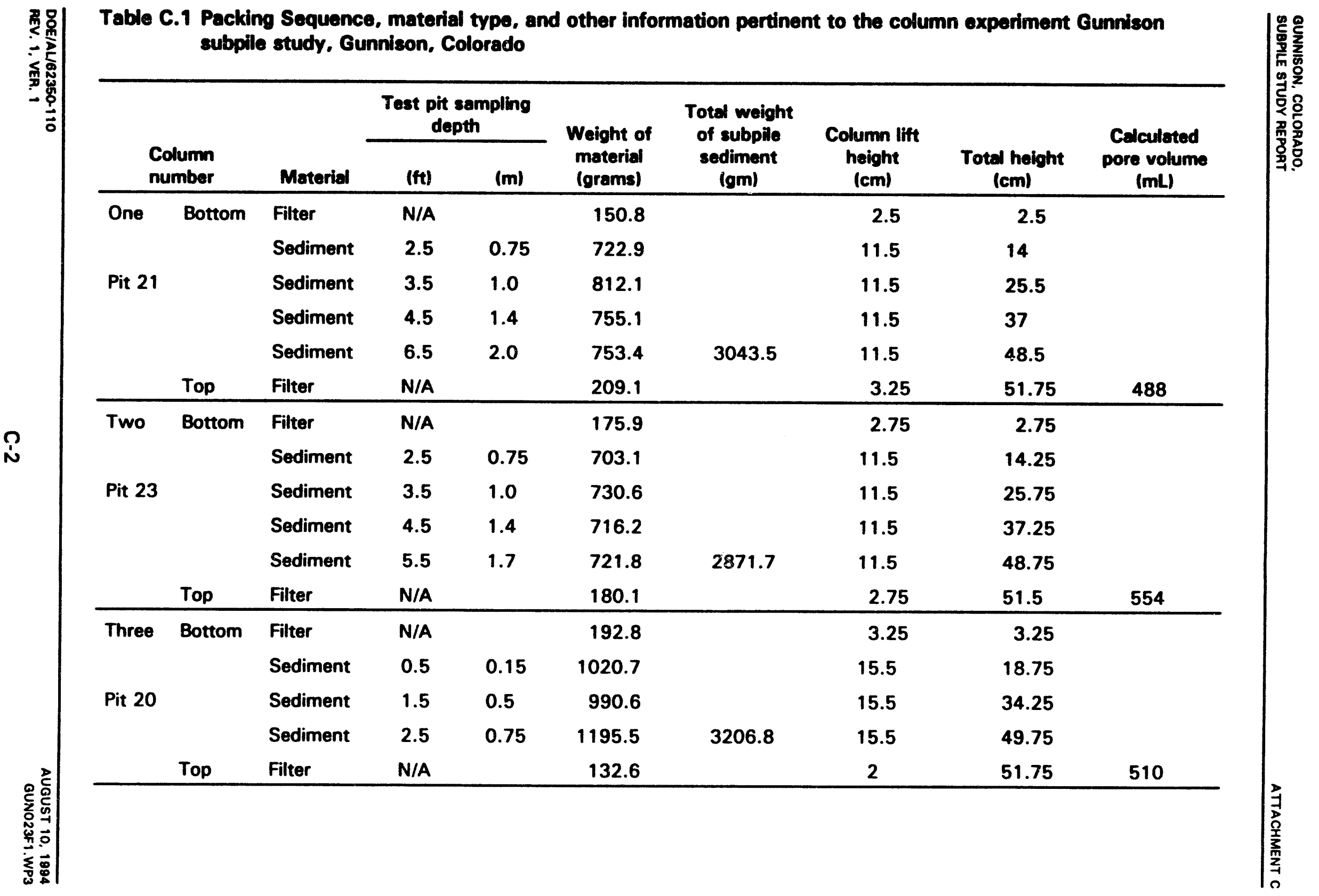




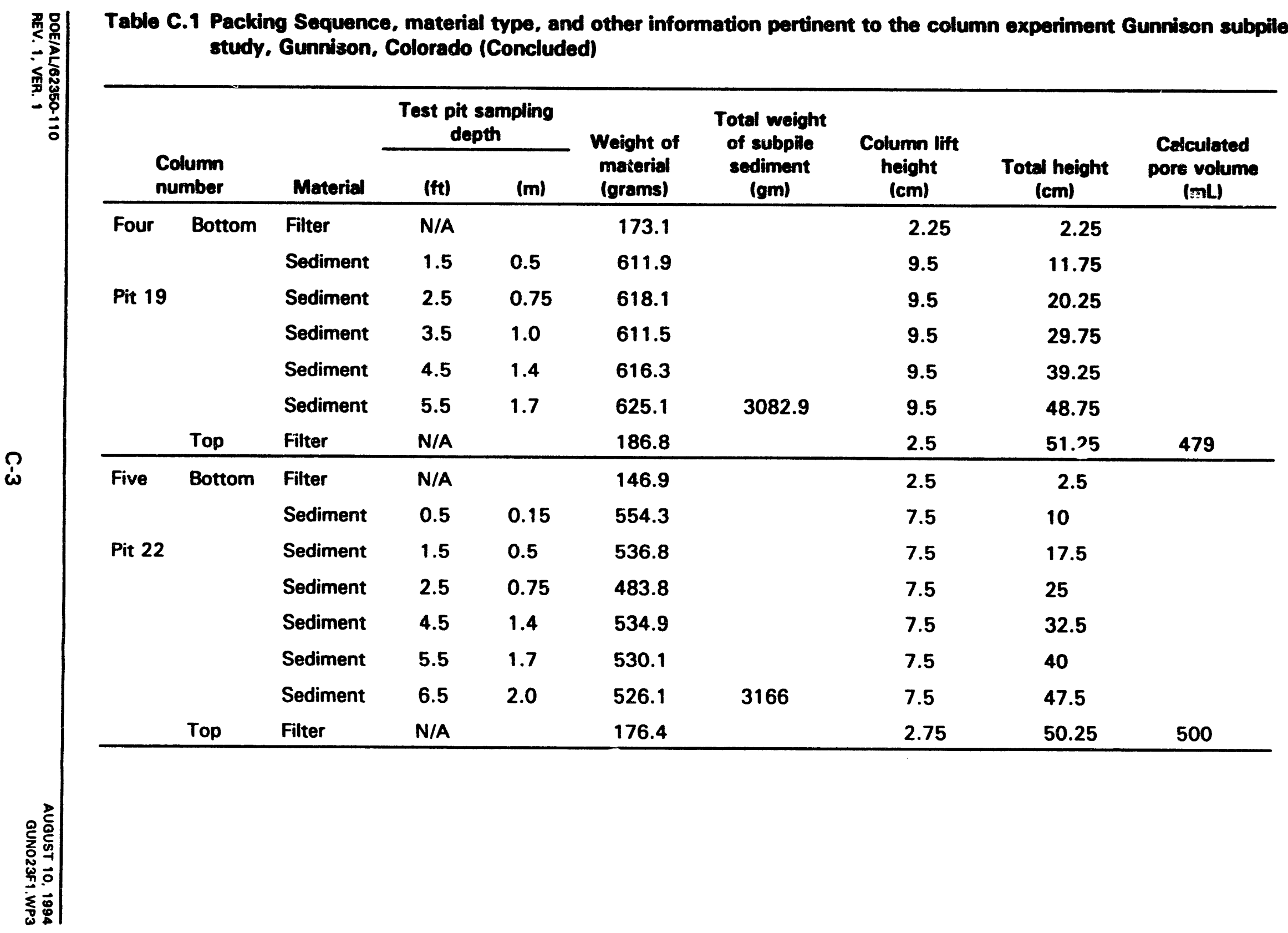



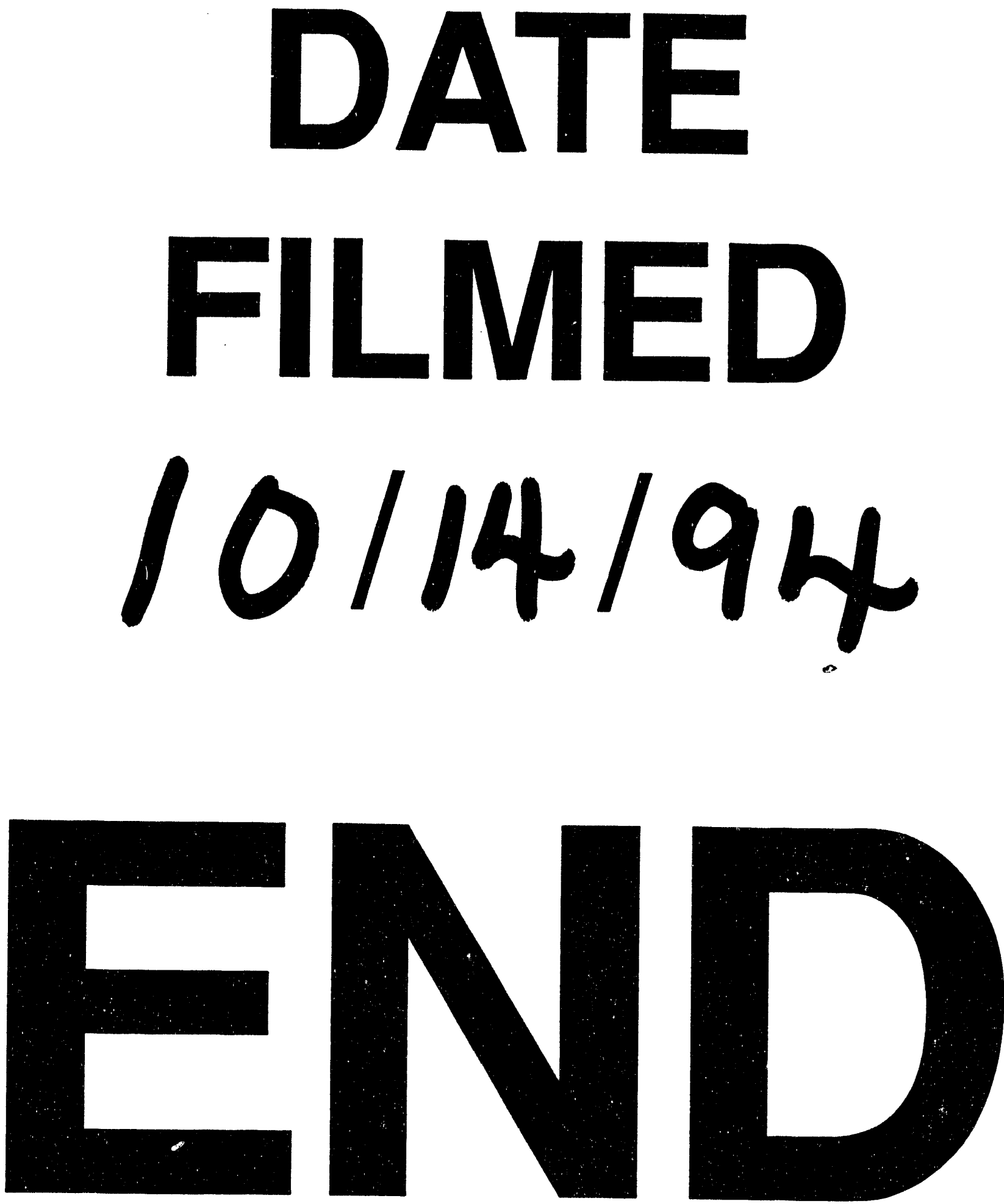
